UNIVERSIDADE DE SÃO PAULO

FACULDADE DE ARQUITETURA E URBANISMO

Programa de Pós-graduação em Arquitetura e Urbanismo

Área de concentração: Planejamento Urbano e Regional

Cecilia Milanez Graziano da Silva

\title{
HABITAÇÃO RURAL: uma luta por cidadania
}

São Paulo - SP 
Cecilia Milanez Graziano da Silva

\section{HABITAÇÃO RURAL: uma luta por cidadania}

Dissertação apresentada para obtenção do título de mestre do curso de Arquitetura e Urbanismo da Universidade de São Paulo.

Área de Concentração: Planejamento Urbano e Regional

Orientadora: Prof ${ }^{a}$. Dra ${ }^{\mathrm{a}}$. Maria de Lourdes Zuquim

São Paulo - SP 
AUTORIZO A REPRODUÇÃO E DIVULGAÇÃO TOTAL OU PARCIAL DESTE TRABALHO, POR QUALQUER MEIO CONVENCIONAL OU ELETRÔNICO, PARA FINS DE ESTUDO E PESQUISA, DESDE QUE CITADA A FONTE.

E-MAIL DA AUTORA: cecilia.graziano@gmail.com

Silva, Cecilia Milanez Graziano da

S586h Habitação rural: uma luta por cidadania / Cecilia Milanez Graziano da Silva. --São Paulo, 2014.

152 p. : il.

Dissertação (Mestrado - Área de Concentração: Planejamento Urbano e Regional) - FAUUSP.

Orientadora: Maria de Lourdes Zuquim

1.Casas rurais 2.Políticas públicas 3.Planejamento habitacional 4.Agricultores I.Título

CDU 728.12 
SILVA, C. M. G. HABITAÇÃO RURAL: uma luta por cidadania. Dissertação apresentada à Faculdade de Arquitetura e Urbanismo da Universidade de São Paulo para obtenção do título de mestre em Planejamento Urbano e Regional.

Aprovado em:

Banca Examinadora:

Prof. Dr. Instituição:

Julgamento: Assinatura:

Prof. Dr. Instituição:

Julgamento: Assinatura:

Prof. Dr. Instituição: 
Aos grandes exemplos de persistência e de luta em busca de seus ideais, José Gomes da Silva e Vera Lucia Graziano da Silva Rodrigues. 
Agradecimentos,

À FAUUSP, pela oportunidade de desenvolver o tema;

À Professora Lourdinha, pela acolhida, incentivo e parceria;

À Tatiana Fadel, pela colaboração;

À minha família, pelo apoio, em especial às minhas irmãs;

Ao Fabrício, meu marido, pelas infindáveis discussões e, sobretudo, pela paciência;

Aos amigos Ramon, Cacá e Amanda, pelas momentos de descontração;

À amiga e parceira Marina Caraffa, pela cumplicidade nessa luta. 
"A sociedade colocou o consumo como fim último, no lugar do bemestar, da busca da felicidade. Hoje, as pessoas acham que a arquitetura é mudança de fachada, como mudam de roupa. A arquitetura não é assim: ela tem fundo social, tem responsabilidade civil."

Marcelo Carvalho Ferraz, Arquiteto, em entrevista à revista Projeto Design, 2002. 


\section{RESUMO}

A dissertação tem como objetivo estudar os avanços e entraves da Política Pública de Habitação Rural para as faixas de renda mais baixas no Brasil a partir da análise dos programas habitacionais rurais em curso no País desde o ano 2000. Para tanto, foi elaborada uma caracterização do mundo rural, de seus sujeitos sociais e de seu novo paradigma, o desenvolvimento rural, bem como das políticas públicas implementadas nestes territórios, para por fim, realizar um levantamento dos programas de habitação rural para os agricultores familiares pobres existentes no País desde o ano 2000. A análise dos avanços e entraves da Política Pública de Habitação Rural para as faixas de renda mais baixa da população brasileira se dá através da comparação do Programa Nacional de Habitação Rural, ou Programa Minha Casa Minha Vida Rural, lançado em 2009, com o Programa Moradia Rural desenvolvido pelo Instituto Nacional de Colonização e Reforma Agrária, em parceria com a Caixa Econômica Federal nos assentamentos rurais de Reforma Agrária do estado de São Paulo em 2006. A investigação conclui, considerando todas as discussões desenvolvidas e os programas apresentados, com possíveis diretrizes para políticas e programas de habitação rural para as faixas de renda mais baixa tendo em vista a superação da pobreza e a dotação de cidadania a esses territórios rurais, historicamente menosprezados no percurso de desenvolvimento do País.

Palavras-chave: Habitação rural. Política pública. Programas de moradia rural. Agricultores familiares. 


\begin{abstract}
The thesis aims to address the progress and obstacles of the Public Policy for Rural Housing for low-income groups in Brazil by analyzing ongoing rural housing programs in the country since 2000. To this end, we developed a characterization of the rural world, of its social subjects and its new paradigm, rural development, as well as of public policies implemented in these territories. Finally, we conducted a survey of rural housing programs for poor family farmers existing in the country since 2000. In order to analyze the progress and obstacles of the Public Policy for Rural Housing for Brazilian low-income groups, we compare the National Rural Housing Program, or Minha Casa Minha Vida Rural, launched in 2009, and the Rural Housing Program developed by the National Institute of Colonization and Agrarian Reform, in partnership with Caixa Economica Federal, in rural settlements of agrarian reform of the state of São Paulo in 2006. The research concludes, considering all the discussions and programs presented, with possible guidelines for policies and for rural housing programs for low- income groups aiming to overcome poverty and provide citizenship to these rural areas, historically overlooked in the development path of the country.
\end{abstract}

Keywords: Rural Housing. Public policy. Programs for rural housing. Family farmers. 


\section{Lista de Mapas}

Mapa 1 - PA pesquisados na PQRA. 47

Mapa 2 - Contratações Moradia Rural INCRA/SP 113

\section{Lista de Tabelas}

Tabela 1 - População nos Censos Demográficos, segundo as Grandes Regiões e a situação do domicílio, 1960 a 2010 .

Tabela 2 - Caracterização dos estabelecimentos agropecuários, de acordo com a classificação de Agricultura Familiar, segundo a Lei no 11.326, Brasil, 2006. 43

Tabela 3 - Estabelecimentos sob condições precárias por grandes regiões, Brasil, 2006 ......... 46

Tabela 4 - Demanda por terra no Brasil. 71

Tabela 5 - Déficit habitacional geral e por componentes para áreas urbanas e rurais, 2007 a 2012

Tabela 6 - Programas de Habitação Rural no Brasil a partir do ano 2000. 87

Tabela 7 - Modalidades de contratos PNHR 2003 a 2009. 88

Tabela 8 - PNHR ou PMCMV Rural: Grupos de contratações, valores, prazos. 94

Tabela 9 - Distribuição de metas físicas PNHR 2011 a 2014. 98

Tabela 10 - Valores máximos das contratações Programa Moradia Rural INCRA/SP. 108

Tabela 11 - Contratações e valores Programa Moradia Rural INCRA/SP 114

\section{Lista de Figuras}

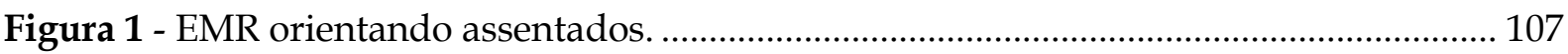

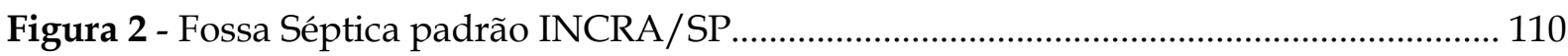

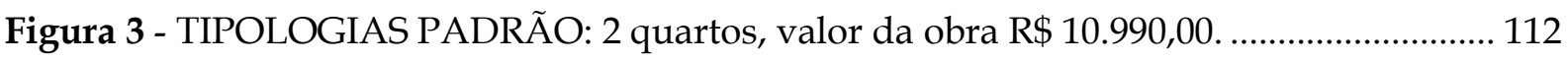

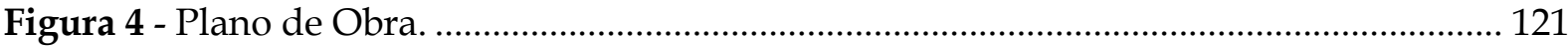

Figura 5 - Casa de adobe no PA Sepé Tiarajú antes e após o colapso. ...................................... 126

\section{Lista de Gráficos}

Gráfico 1 - Percepção de melhoria na condição após o assentamento (muito melhor ou melhor).

Gráfico 2 - Execução anual de famílias assentadas - INCRA - Brasil, até 2012 


\section{Lista de Siglas}

\begin{tabular}{|c|c|}
\hline I PNRA & Primeiro Plano Nacional de Reforma Agrária \\
\hline II PNRA & Segundo Plano Nacional de Reforma Agrária \\
\hline $\mathrm{AF}$ & Agricultor Familiar \\
\hline AGF & Agência Gaúcha de Fomento \\
\hline ATEC & Assistência Técnica \\
\hline ATES & $\begin{array}{l}\text { Programa de Assessoria Técnica, Social e Ambiental à Reforma } \\
\text { Agrária }\end{array}$ \\
\hline $\mathrm{BB}$ & Banco do Brasil \\
\hline $\mathrm{BNH}$ & Banco Nacional da Habitação \\
\hline CADIN & $\begin{array}{l}\text { Cadastro Informativo de Créditos não Quitados do Setor Público } \\
\text { Federal }\end{array}$ \\
\hline CADMUT & Cadastro Nacional de Mutuários \\
\hline CC-FGTS & Programa Carta de Crédito FGTS \\
\hline Cooperhaf & $\begin{array}{l}\text { Cooperativa de Habitação dos Agricultores Familiares dos Três } \\
\text { Estados do Sul }\end{array}$ \\
\hline CRE & Comissão de Representantes \\
\hline CRENHOR & Cooperativa de Crédito Novos Horizontes de Novo Sarandi \\
\hline CUT & Central Única dos Trabalhadores \\
\hline DAP & Declaração de Aptidão ao PRONAF \\
\hline DECiv UFSCar & $\begin{array}{l}\text { Departamento de Engenharia Civil da Universidade Federal de São } \\
\text { Carlos }\end{array}$ \\
\hline DF & Distrito Federal \\
\hline EESC & Escola de Engenharia de São Carlos \\
\hline Emater & Empresas de Assistência Técnica e Extensão Rural \\
\hline EMR & Equipe de Moradia Rural INCRA/SP \\
\hline $\mathrm{EO}$ & Entidade Organizadora \\
\hline FAAFOP & $\begin{array}{l}\text { Federação das Associações dos Assentados e Agricultores } \\
\text { Familiares do Oeste Paulista }\end{array}$ \\
\hline $\mathrm{FAO}$ & Organização das Nações Unidas para Alimentação e Agricultura \\
\hline FAPESP & Fundação de Amparo à Pesquisa do Estado de São Paulo \\
\hline FAS & Fundo de Apoio ao Desenvolvimento Social \\
\hline FAT & Fundo de Amparo ao Trabalhador \\
\hline FAUUSP & $\begin{array}{l}\text { Faculdade de Arquitetura e Urbanismo da Universidade de São } \\
\text { Paulo }\end{array}$ \\
\hline FDS & Fundo de Desenvolvimento Social \\
\hline FFLCH & Faculdade de Filosofia, Letras e Ciências Humanas \\
\hline FGTS & Fundo de Garantia do Tempo de Serviço \\
\hline FINEP & Financiadora de Estudos e Projetos \\
\hline FNHIS & Fundo Nacional de Habitação de Interesse Social \\
\hline Funasa & Fundação Nacional de Saúde \\
\hline GERAH & Grupo de Estudos em Reforma Agrária e Habitat da Universidade \\
\hline
\end{tabular}




\begin{tabular}{|c|c|}
\hline & Federal do Rio Grande do Norte \\
\hline HABIS & Grupo de Pesquisa em Habitação e Sustentabilidade \\
\hline HIS & Habitação de Interesse Social \\
\hline IAU-USP & Instituto de Arquitetura e Urbanismo da Universidade de São Paulo \\
\hline IBGE & Instituto Brasileiro de Geografia e Estatística \\
\hline IBRA & Instituto Brasileiro de Reforma Agrária \\
\hline IDH & Índice de desenvolvimento humano \\
\hline IN & Instruções normativas \\
\hline INCRA & Instituto Nacional de Colonização e Reforma Agrária \\
\hline INDA & Instituto Nacional de Desenvolvimento Agrário \\
\hline INSS & Instituto Nacional de Seguridade Social \\
\hline IPEA & Instituto de Pesquisa Econômica Aplicada \\
\hline ITESP & $\begin{array}{l}\text { Fundação Instituto de Terras do Estado de São Paulo "José Gomes } \\
\text { da Silva" }\end{array}$ \\
\hline ITR & Imposto Territorial Rural \\
\hline LINS & Local incerto e não sabido \\
\hline MAPA & Ministério da Agricultura, Pecuária e Abastecimento \\
\hline MCidades & Ministério das Cidades \\
\hline MDA & Ministério do Desenvolvimento Agrário \\
\hline MDS & Ministério de Desenvolvimento Social e Combate à Fome \\
\hline MERCOSUL & Mercado Comum do Sul \\
\hline MIRAD & Ministério da Reforma e do Desenvolvimento Agrário \\
\hline MMA & Ministério do Meio Ambiente \\
\hline MPA & Movimento dos Pequenos Agricultores \\
\hline MST & Movimento dos Trabalhadores sem Terra \\
\hline NE & Norma de execução \\
\hline OGU & Orçamento Geral da União \\
\hline ONU & Organização das Nações Unidas \\
\hline PAA & Programa de Aquisição de Alimentos \\
\hline PAC & Programa de Aceleração do Crescimento \\
\hline PA & Projeto de Assentamento de Reforma Agrária \\
\hline PDA & Plano de Desenvolvimento do Assentamento \\
\hline PDSTR & Programa de Desenvolvimento Sustentável dos Territórios Rurais \\
\hline PE & Projeto de Assentamento Estadual \\
\hline PHPE & Programa Habitacional Popular Entidades \\
\hline PIB & Produto Interno Bruto \\
\hline Planapo & Plano Nacional de Agroecologia e Produção Orgânica \\
\hline PlanHab & Plano Nacional de Habitação \\
\hline PMCMV & Programa Minha Casa Minha Vida \\
\hline PMCMV Rural & Programa Minha Casa Minha Vida Rural \\
\hline PNAD & Pesquisa Nacional por Amostra de Domicílios \\
\hline PNAE & Programa Nacional de Alimentação Escolar \\
\hline PNCF & Programa Nacional de Crédito Fundiário \\
\hline PNHR & Programa Nacional de Habitação Rural \\
\hline PNHU & Programa Nacional de Habitação Urbana \\
\hline
\end{tabular}


PQRA Pesquisa sobre a qualidade de vida, produção e renda nos assentamentos da Reforma Agrária

PRA Programa Recuperação de Materiais de Construção

PROCERA Programa Especial de Crédito para a Reforma Agrária

PROGER Programa de Geração de Emprego e Renda

PRONAF Programa Nacional de Fortalecimento da Agricultura Familiar

PSH Programa de Subsídio à Habitação de Interesse Social

RB Relação de Beneficiários

RPA Recibo de pagamento a autônomo

SAF Secretaria da Agricultura Familiar

SDT Secretaria de Desenvolvimento Territorial

SERFAL Secretaria Extraordinária de Regularização Fundiária na Amazônia Legal

SINAPI Sistema Nacional de Pesquisa de Custos e Índices da Construção Civil

SINTRAF Sindicatos dos Trabalhadores na Agricultura Familiar

SM Salário Mínimo

SNCR Sistema Nacional de Cadastro Rural

SNHIS Sistema Nacional de Habitação de Interesse Social

SRA Secretaria de Reordenamento Agrário

SR Superintendência Regional

SUPRA Superintendência de Política Agrária

TCPO Tabela de Composição de Preços e Orçamentos

TS Trabalho Social

UA Unidade Avançada

UDR União Democrática Ruralista

UFG Universidade Federal de Goiás

UFRGS Universidade Federal do Rio Grande do Sul

UFRN Universidade Federal do Rio Grande do Norte

UFSCar Universidade Federal de São Carlos

UH Unidades Habitacionais 


\section{SUMÁRIO}

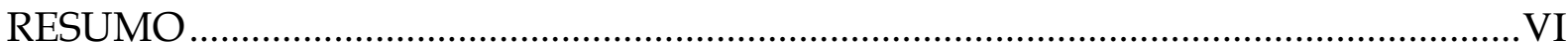

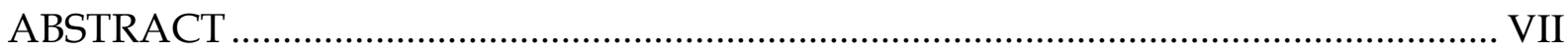

Lista de Mapas ............................................................................................................

Lista de Tabelas.................................................................................................... VIII

Lista de Figuras................................................................................................ VIII

Lista de Gráficos ......................................................................................................... VIII

Lista de Siglas ..................................................................................................

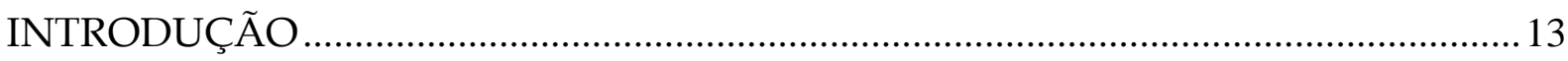

Capítulo 01 - O MUNDO RURAL: território, desenvolvimento e sujeitos sociais......21

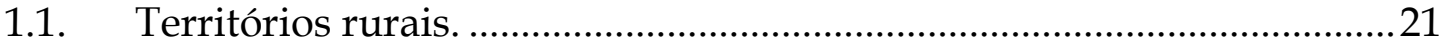

1.2. Desenvolvimento Rural .............................................................................

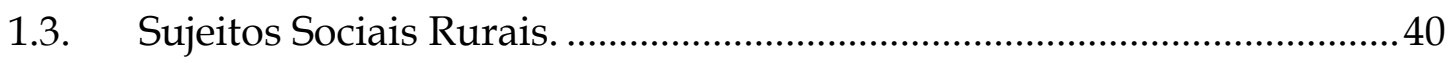

Capítulo 02 - POLÍTICAS PÚBLICAS PARA O MUNDO RURAL: da política agrária e agrícola à cidadania rural. ..........................................................................................52

2.1. Políticas Públicas para o mundo rural.....................................................52

2.2. Rápida contextualização da Reforma Agrária no Brasil ...........................60

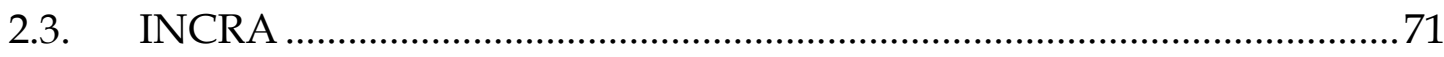

Capítulo 03 - HABITAÇÃO RURAL - dos primeiros programas ao Minha Casa

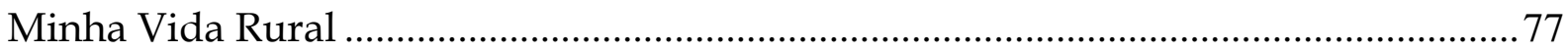

3.1. Habitação Rural - direito ou mercadoria? ..................................................77

3.2. Programas de Habitação Rural .................................................................... 86

Capítulo 04 - EXPERIÊNCIAS DE HABITAÇÃO RURAL..................................................99

4.1. A contribuição de universidades e movimentos sociais. .........................99

4.2. O Programa Moradia Rural INCRA/SP...................................................103

4.3. O aprendizado a partir do Programa Moradia Rural INCRA/SP. ....130

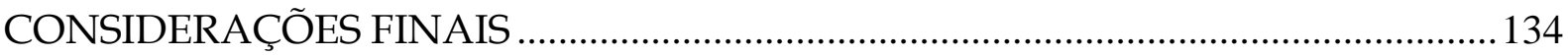

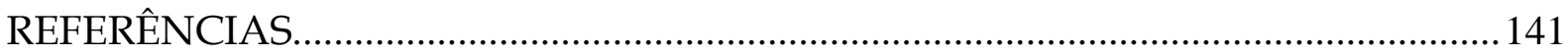




\section{INTRODUÇÃO}

O tema da habitação rural configura-se, no Brasil, como uma questão que ainda carece de qualificação e reflexão não apenas em seu aspecto teórico e prático, mas, sobretudo, político. A habitação rural se torna um objeto de estudo desconhecido a partir do momento em que a própria sociedade desconhece o mundo rural que compõe juntamente com o urbano as cidades onde se vive.

O entendimento do mundo rural passa por sua base territorial, por seus sujeitos sociais e por um conjunto de laços sociais que valorizam relações diretas de interconhecimento, ou ainda pela economia de proximidade (ABRAMOVAY, 2009) ou pertencimento.

O território se materializa em consequência de como sujeitos sociais usam a terra, como organizam o espaço e como dão significado ao lugar. Dessa forma, a construção de um território se dá a partir da trama de relações e de práticas sociais que sujeitos imprimem através de suas características socioculturais em determinados espaços, criando identidade, pertencimento. Não por acaso, etimologicamente, a palavra território vem do latim territorium, que significa pedaço de terra apropriado.

Partimos do entendimento de que a moradia rural é um elemento de fixação do homem a terra, é sua residência. Mas mais do que uma mercadoria, a moradia rural é uma prática familiar. Enquanto no urbano os locais de trabalho e de moradia quase sempre se constituem em espaços físicos distintos, no mundo rural, esses espaços se constituem em uma unidade física e espacial única - o lote ou o sítio, onde diversas escalas de trabalho, lazer e de interação comunitária e social acontecem. Nessa perspectiva, a moradia rural se torna elemento fundamental dos territórios rurais. 
Em um país como o Brasil, de dimensões continentais, onde a produção agropecuária ainda está no centro do desenvolvimento econômico, o mundo rural deveria ser foco de estudos, pesquisas e reflexões de diversas disciplinas. Mas essa questão é quase sempre "deixada de lado" por arquitetos e planejadores, que estão debruçados sobre as áreas urbanas das cidades.

Olhar o urbano exige, de fato, uma interdisciplinaridade já percebida. Mas nós, arquitetos, ainda não descobrimos o universo de potencialidades que o desenvolvimento rural pode trazer à sociedade brasileira. Também não se percebeu que o rural faz parte das cidades. E por fim, não se percebeu que devemos tratar o território onde nossa sociedade se assenta, qual seja: rural e urbano, para trabalhar nosso desenvolvimento, não só econômico, mas principalmente o social.

No Brasil, a forma dominante de classificação dos territórios rurais se dá a partir da abordagem administrativo-econômica, que resulta no estabelecimento de perímetros urbanos. Isso deixa claro que o rural é definido, na maior parte dos casos, por arbítrio dos poderes públicos municipais, para os quais a questão fiscal acaba sendo mais importante que os aspectos geográficos, sociais, econômicos ou culturais.

O processo de expansão urbana, pautado principalmente pelos interesses do mercado e das elites, se deu através da expansão extensiva, fragmentada, descontínua, espraiada e desestruturada das aglomerações urbanas. Impulsionado pela migração de um vasto contingente de pobres, o resultado foi o transbordamento dos assentamentos precários para as áreas fora dos centros urbanizados, e, consequentemente,a distribuição desigual dos bens e serviços públicos no território.

Dessa forma, ocorreu a formação de aglomerações urbanas densas e polarizadas na sociedade brasileira: centro moderno ou cidade formal de um lado, e de outro a periferia pobre ou a cidade informal. Nessa lógica, as áreas rurais são encaradas como estoque de áreas a serem urbanizadas, sem qualquer consideração pelas suas características territoriais, como seus usos históricos, sua população e suas práticas sociais.

Assim, o que vigora é a ideia de que o urbano substitua o rural, o que resulta na transformação do rural num espaço suburbano, precário, sem infraestrutura, sem 
serviços públicos, sem cidadania. E é aqui exatamente onde se encontram os sujeitos sociais concernentes a esta pesquisa, aqueles que mais sofrem sem acesso à cidadania no mundo rural brasileiro: os pequenos agricultores familiares pobres.

As relações entre rural e urbano no Brasil são historicamente diferenciadas, mas nem sempre foram opostas ou antagônicas. A partir dos anos 80, o rural e urbano passaram a ser vistos como complementares, fruto da percepção de novas dinâmicas sociais, de alterações econômicas nas cadeias produtivas, no comércio e nos fluxos de capital entre esses espaços.

Dessa forma, a integração rural-urbana passa a ser vista como ponto de partida para o desenvolvimento territorial brasileiro, e o desenvolvimento rural começa a substituir, como paradigma, a modernização da agricultura - ou a modernização conservadora, que produziu uma mudança técnica sem alterações na estrutura agrária, que permanece extremamente concentrada na sociedade brasileira.

Parte-se do pressuposto que uma política de habitação rural não pode ser elaborada isoladamente, mas sim associada e referenciada por uma política de desenvolvimento territorial rural. Então os programas de habitação rural não devem se limitar à provisão habitacional, mas devem se articular com políticas fundiárias, de saneamento ambiental, de geração de trabalho e renda, etc. Assim, a habitação rural se configura não só como direito fundamental humano, mas como promotora do desenvolvimento territorial rural, e consequentemente, do desenvolvimento do País.

Portanto, com a política estabelecendo princípios, metas e objetivos a serem alcançados, os planos e programas podem ser elaborados, para a efetiva aplicação da política. Mas somente em 2003 um Programa Nacional de Habitação Rural (PNHR) é instituído no Brasil. Até essa data, iniciativas de universidades ou movimentos sociais tentavam dar conta das demandas por moradia rural, operando programas urbanos já existentes, adaptados à realidade rural. Assim, não havia uma política pública de habitação rural, nem mesmo uma política pública de habitação, que foi instituída apenas em 2004. 
A Política Nacional de Habitação (PNH), aprovada em 2004, se apoiava na criação de um Sistema Nacional de Habitação, no Desenvolvimento Institucional, Sistema de Informação, Avaliação e Monitoramento da Habitação, e o Plano Nacional de Habitação.

O Sistema Nacional de Habitação se estruturou em dois subsistemas: a habitação de interesse social e a habitação de mercado, com distinção de fontes de recursos e de faixas de renda que cada subsistema atingiria. O primeiro visava garantir que os recursos públicos fossem destinados exclusivamente ao subsídio à população de baixa renda, enquanto o segundo subsistema buscava reorganizar o mercado privado de habitação, ampliando as formas de captação de recursos e de novo agentes, incrementando a promoção imobiliária.

Um dos principais instrumentos do subsistema de habitação de interesse social, o Sistema Nacional de Habitação de Interesse Social (SNHIS), juntamente com seu Fundo e Conselho, foram instituídos pela Lei $\mathrm{n}^{\mathrm{o}} 11.124 / 05^{1}$, que exigiu de estados e municípios a criação de uma estrutura institucional, com fundo, conselho e plano de habitação, para que tivessem acesso aos recursos federais.

O Desenvolvimento Institucional baseava-se na estruturação institucional de Estados, Distrito Federal e Municípios, bem como na capacitação de agentes públicos, sociais, técnicos e privados para a implementação da PNH. Já o Sistema de Informação, Avaliação e Monitoramento da Habitação visava garantir um processo permanente de revisão e redirecionamento da PNH e de seus programas.

Por fim, o Plano Nacional de Habitação (PlanHab) visava estabelecer metas de médio e longo prazo, linhas de financiamento, programas de provisão, urbanização e modernização da produção habitacional a serem implementados a partir das

1 O SNHIS, juntamente com seu Fundo e Conselho, foram instituídos pela Lei $\mathrm{n}^{\mathrm{o}}$ 11.124/05, que exigiu de estados, DF e municípios a criação de uma estrutura institucional, com fundo, conselho e plano de habitação, para que tivessem acesso aos recursos federais. Compõem recursos do SNHIS: o Fundo de Amparo ao Trabalhador (FAT), FGTS, e o FNHIS (composto principalmente por recursos do Fundo de Apoio ao Desenvolvimento Social FAS e OGU). 
prioridades regionais, de acordo com perfil do déficit habitacional nacional (BRASIL, 2010a).

O PlanHab foi gestado por dois anos como um plano estratégico de longo prazo, e considerava a diversidade da questão habitacional, as variadas categorias de municípios, as especificidades regionais e os diferentes olhares de cada segmento social. A estratégia do PlanHab se estruturou em ações simultâneas em quatro eixos: financiamentos e subsídios; arranjos institucionais; cadeia produtiva da construção civil; estratégias urbano-fundiárias (BONDUKI, 2009).

Assim, o PlanHab estabeleceu alguns princípios e diretrizes para a gestão das cidades, apontou mecanismos para baratear a produção e facilitar o acesso ao crédito para as camadas médias e baixas, ressaltando a necessidade de subsidiar a moradia dos mais pobres, e lançou questões fundamentais para o mundo rural: a adaptação das linhas de financiamento à realidade rural, com destaque para as linhas de financiamento voltadas à melhoria do imóvel (instalação de unidades sanitárias, soluções apropriadas de esgotamento sanitário, abastecimento de água e energia elétrica) e a produção por autogestão de unidades habitacionais rurais.

Mas, em 2009, antes do lançamento do PlanHab, é lançado o Programa Minha Casa Minha Vida (PMCMV), com um subprograma direcionado ao mundo rural que passou a concentrar todas as ações de provisão de moradia rural do governo: o Programa Minha Casa Minha Vida Rural (PMCMV Rural).

Como meta inicial, o PMCMV comportou a construção de um milhão de moradias urbanas e rurais para famílias com renda de até 10 salários mínimos (SM), em parceria com estados, municípios e iniciativa privada, num investimento de $\mathrm{R} \$ 34$ bilhões, que poderia reduzir em 14\% o déficit habitacional do país (IPEA, 2011). Em sua segunda versão, mais dois milhões de moradias deverão ser produzidas até 2014.

Construir moradias é produzir cidades. É essencial discutir os impactos dos empreendimentos imobiliários nas condições de vida, na instituição ou destituição de direitos sociais, no ordenamento territorial e no funcionamento das cidades. No Brasil, as cidades são marcadas por profundas expressões de desigualdades e exclusões socioterritoriais, e o principal sentido dos processos de produção de 
moradias é engendrar cidades e urbanidades para garantir o bemestar e o desenvolvimento das pessoas. Estamos diante de uma bela oportunidade. Não vamos cair nas armadilhas sedutoras dos números: 1 milhão de moradias? Sim, mas onde, como e para quem? (ROLNIK; NAKANO, 2009, n.p.).

Segundo BONDUKI (2009), o "pacote habitacional" do PMCMV tem origem a partir da crise econômica internacional de 2008, que gerou uma paralisia no setor imobiliário brasileiro e forte queda nas atividades das empresas de construção civil. Assim, esse programa surge como uma "ação emergencial anticíclica" de apoio ao setor privado, dinamizando a construção civil, para evitar o desemprego.

O PMCMV passou a encabeçar a atuação do governo federal na provisão habitacional. Assim, o SNHIS teve a partir desse momento um direcionamento quase que exclusivo para ações de urbanização de assentamentos precários urbanos, incluindo o apoio a ações já em andamento no âmbito do Programa de Aceleração do Crescimento (PAC), praticamente deixando de apoiar a provisão pública de habitação de interesse social (HIS). Esta alocação de recursos habitacionais em outros marcos legais, como o PMCMV, pode levar a situações de competição por recursos, de pulverização da capacidade de gestão dos entes federativos e de não conformidade ao planejamento territorial e setorial (IPEA, 2011).

Assim, enquanto o PlanHab estrutura uma política habitacional, o PMCMV se configura como um programa de produção de unidades habitacionais, e que responde mais a estratégias de alavancagem do desenvolvimento econômico do País.

A preocupação que deu origem a este trabalho surgiu exatamente a partir do questionamento da existência de uma Política Publica de Habitação Rural no Brasil, principalmente após a instituição do PMCMV Rural, que reuniu diversos programas que vinham sendo executados por movimentos sociais no mundo rural. Além desses questionamentos, a idealização e a execução do Programa de Moradia Rural desenvolvido pelo INCRA/SP em parceria com a Caixa Econômica Federal em 2006, e que se tornou um dos mais abrangentes programas habitacionais para os assentamentos de Reforma Agrária do estado de São Paulo, foi a base fundante para o inicio da investigação que hoje resulta nesta dissertação sobre Habitação Rural no Brasil. 
Assim, esta dissertação tem como objetivo estudar os entraves e os avanços da Política Pública de Habitação Rural para as faixas de renda mais baixas no Brasil a partir da análise dos programas habitacionais rurais em curso no País desde o ano 2000.

Dessa forma, a investigação se inicia trazendo em seu Capítulo 1 a caracterização do mundo rural brasileiro, de seus sujeitos sociais e de seu novo paradigma, o desenvolvimento territorial rural, para uma melhor aproximação do objeto da pesquisa.

No Capítulo 2, será apresentado o conjunto das principais políticas públicas implementadas nos territórios rurais, evidenciando seu viés agrícola, e discutindo sua aderência à prerrogativa de desenvolvimento territorial rural.

No Capítulo 3, é realizado um levantamento dos programas de habitação rural existentes no País desde o ano 2000, até a instituição do PMCMV Rural em 2009, ressaltando os avanços e retrocessos resultantes na construção do atual programa de habitação rural em curso no País.

O Capítulo 4 traz o levantamento de algumas experiências de produção de habitação rural, a partir de iniciativas de universidades, movimentos sociais e cooperativas rurais, visto que não podemos ignorar essas iniciativas, pois muitos avanços na luta por dignidade no mundo rural são fruto da pressão dos movimentos sociais organizados, principalmente os de luta pela terra.

Também neste capítulo 4 é feito uma minuciosa descrição do Programa Moradia Rural INCRA/SP, já ressaltando seus aspectos relevantes em relação aos avanços e retrocessos verificados no PMCMV Rural.

As considerações finais tratam do confrontamento dos erros e acertos de todos esses programas de habitação relatados anteriormente, bem como do Moradia Rural INCRA/SP e PMCMV Rural, para por fim concluir com possíveis diretrizes para políticas e programas de habitação rural para as faixas de renda mais baixa, tendo em vista a superação da pobreza e a dotação de cidadania a esses territórios rurais, historicamente menosprezados no percurso de desenvolvimento do Brasil. 
Como procedimentos metodológicos a investigação se valeu de pesquisa bibliográfica e documental, a fim de balizar a dissertação teórica e historicamente, dada a necessidade de aprofundar o conhecimento referente ao mundo rural, seus sujeitos sociais, e ainda referente aos programas habitacionais e iniciativas dos movimentos sociais executados no País. A investigação contou também com trabalhos próprios de investigação em alguns locais de implantação dos programas, bem como com a experiência vivida a partir do Programa Moradia Rural em São Paulo. 


\section{Capítulo 01 - O MUNDO RURAL: território, desenvolvimento e sujeitos sociais.}

\subsection{Territórios rurais.}

O mundo rural brasileiro vem sendo palco de profundas transformações no período atual, particularmente a partir dos anos 1960. Essas transformações nestes territórios rurais, e também na relação rural-urbano, têm desafiado estudiosos a desenvolverem teorias e conceitos que expliquem essa nova realidade.

É possível afirmar que não existe uma definição consagrada de rural. Alguns estudiosos chegam a decretar seu fim, outros admitem o seu renascimento, e ainda, há uma vertente que opta por uma análise territorial para a compreensão do que é o mundo rural. O que é possível dizer é que existe um hábito no discurso, principalmente no Brasil (e não só do senso comum, mas também dos intelectuais), que associa o rural ao atraso, à carência de serviços e à falta de cidadania.

No Brasil a forma dominante de classificação dos territórios rurais é a partir da delimitação administrativa e vigora desde o Decreto-Lei n 311 de 1938, do governo de Getúlio Vargas. Esse decreto transformou em cidades todas as sedes municipais existentes, e vila, toda sede de distrito, mesmo tendo características econômicas, funcionais e dimensionais completamente diferentes (ZUQUIM, 2008). De acordo com o Decreto, as áreas urbanas são as internas aos perímetros urbanos, e as áreas rurais, as externas a esses perímetros.

A Constituição de 1988 adotou a Federação como forma de Estado, e a organização político-administrativa da República Federativa do Brasil passou a compreender a União, os Estados, o Distrito Federal (DF) e os Municípios como entes federativos dotados de autonomia. O município é entendido como o conjunto das áreas urbanas e rurais pertencentes ao controle de uma administração municipal. 
Assim, a sede do município, ou seja, sua parte urbana - delimitada por um perímetro urbano - é entendida como cidade. O "restante" é entendido como rural.

A definição do IBGE (Instituto Brasileiro de Geografia e Estatística) considera esse caráter administrativo assumido pelas cidades, em que as áreas rurais são aquelas que se encontram fora de seus limites, cujo estabelecimento fica a cargo das prefeituras municipais ${ }^{2}$. O estabelecimento desses limites assume, além do caráter administrativo, o caráter econômico, pois quanto maior for a área urbana do município, maior será sua arrecadação fiscal.

Ainda sobre o caráter econômico ou fiscal, a competência em instituir impostos sobre a propriedade territorial rural é da União, dada pelo artigo 153 de nossa Constituição ${ }^{3}$. E aqui se insere uma superposição de poderes, e ainda uma disputa, com dois entes federativos legislando ao mesmo tempo sobre o município: a União tratando das áreas rurais e o Poder Municipal, das áreas urbanas.

Essa abordagem administrativo-econômica deixa claro que o rural é definido, na maior parte dos casos, por arbítrio dos poderes públicos municipais. Por isso, a questão fiscal acaba sendo mais importante que os aspectos geográficos, sociais, econômicos ou culturais. Ademais, desde que haja alguma extensão de serviços públicos a um aglomerado populacional, ele tenderá a ser definido como urbano, e

2 A definição de rural e urbano utilizada pelo Censo 2010 é dada a partir da definição da situação do domicílio: "segundo sua localização, o domicílio é classificado como domicílio de situação urbana ou rural. Os domicílios de situação urbana são aqueles localizados nas áreas urbanas, que são as áreas internas ao perímetro urbano de uma cidade ou vila, definido por lei municipal. As áreas urbanas são classificadas em área urbanizada, área não urbanizada e área urbana isolada. Os domicílios de situação rural são aqueles localizados nas áreas rurais, definidas como áreas externas aos perímetros urbanos, inclusive nos aglomerados rurais de extensão urbana, povoados, núcleos e outros aglomerados" (IBGE 2011b).

3 Até 2008, apenas 50\% do ITR (Imposto Territorial Rural) arrecadado pela União era repassado aos municípios. Depois de sancionado o Projeto de Lei $\mathrm{n}^{\circ} 4.896 / 2005$, no início de 2008 , foi regulamenta a transferência integral do imposto para os municípios. Os Decretos $n^{\circ}$ 6.433 de 15 de abril de 2008, $n^{\circ} 6.621$ de 29 de outubro de 2008 e ainda o Decreto $n^{\circ} 6.770$ de 10 de fevereiro de 2009 permitem aos municípios celebrar convênio com a União para assumir a responsabilidade sobre o imposto, incluindo a arrecadação e fiscalização das propriedades rurais. Os municípios que não fizerem convênio com a União continuarão a receber apenas a metade do ITR. 
consequentemente, o rural tenderá a ser definido pela carência desses serviços (ABRAMOVAY, 2000).

Dessa forma, a cada publicação censitária, assistimos ao rural perder população para o urbano (Tabela 1).

Tabela 1 - População nos Censos Demográficos, segundo as Grandes Regiões e a situação do domicílio, 1960 a 20104.

\begin{tabular}{|c|c|c|c|c|c|c|c|c|c|c|c|c|}
\hline $\begin{array}{l}\text { Grandes } \\
\text { Regiões }\end{array}$ & $\begin{array}{c}1960 \\
\text { Urbana }\end{array}$ & $\begin{array}{l}1960 \\
\text { Rural }\end{array}$ & $\begin{array}{c}1970 \\
\text { Urbana }\end{array}$ & $\begin{array}{l}1970 \\
\text { Rural }\end{array}$ & $\begin{array}{c}1980 \\
\text { Urbana }\end{array}$ & $\begin{array}{l}1980 \\
\text { Rural }\end{array}$ & $\begin{array}{c}1991 \\
\text { Urbana }\end{array}$ & $\begin{array}{l}1991 \\
\text { Rural }\end{array}$ & $\begin{array}{c}2000 \\
\text { Urbana }\end{array}$ & $\begin{array}{l}2000 \\
\text { Rural }\end{array}$ & $\begin{array}{c}2010 \\
\text { Urbana }\end{array}$ & $\begin{array}{l}2010 \\
\text { Rural }\end{array}$ \\
\hline BRASIL & 32.004 .817 & 38.987 .526 & 52.904 .744 & 41.603 .839 & 82.013 .375 & 39.137 .198 & 110.875 .826 & 36.041 .633 & 137.755 .550 & 31.835 .143 & 160.925 .792 & 29.830 .007 \\
\hline Norte & 1.041 .213 & 1.888 .792 & 1.784 .223 & 2.404 .090 & 3.398 .897 & 3.368 .352 & 5.931 .567 & 4.325 .699 & 9.002 .962 & 3.890 .599 & 11.664 .509 & 4.199 .945 \\
\hline Nordeste & 7.680 .681 & 14.748 .192 & 11.980 .937 & 16.694 .173 & 17.959 .640 & 17.459 .516 & 25.753 .355 & 16.716 .870 & 32.929 .318 & 14.763 .935 & 38.821 .246 & 14.260 .704 \\
\hline Sudeste & 17.818 .649 & 13.244 .329 & 29.347 .170 & 10.984 .799 & 43.550 .664 & 9.029 .863 & 55.14 & 7.511 .263 & 65.44 & 6.855 .835 & 74.696 .178 & 5.668 .232 \\
\hline Sul & 4.469 .103 & 7.423 .004 & 7.434 .196 & 9.249 .355 & 12.153.971 & 7.226 .155 & 16.392 .710 & 5.724 .316 & 20.306 .542 & 4.783 .241 & 23.260 .896 & 4.125 .995 \\
\hline $\begin{array}{c}\text { Centro- } \\
\text { Oeste }\end{array}$ & 995.171 & 1.683 .209 & 2.358 .218 & 2.271 .422 & 4.950 .203 & 2.053 .312 & 7.648 .757 & 1.763 .485 & 10.075 .212 & 1.541 .533 & 12.482 .963 & 1.575.131 \\
\hline
\end{tabular}

Fonte: IBGE, [2011a], adaptado para o presente trabalho.

O censo de 2010 nos mostra que 84,36\% da população brasileira é urbana e apenas $15,46 \%$ é rural. Porém essa constatação contrasta com sinais de vitalidade observados em certos territórios rurais. Assim, essas definições passam a ser bastante questionadas por vários autores por considerarem apenas as delimitações administrativas para a definição de rural e urbano.

[...] Veiga $(2001)^{5},[\ldots]$ aponta o caráter irrealista do nosso grau de urbanização medido pelo critério administrativo atualmente em vigor e propõe um cálculo mais realista, como o adotado pela maioria dos países desenvolvidos, baseado no tamanho e densidade da população dos municípios. Com isto chega a uma estimativa de que apenas $60 \%$ da população brasileira [no ano 2000] pode ser considerada urbana e que em determinadas áreas rurais a população tem crescido até mais do que na área urbana. (KAGEYAMA, 2008, p. 51).

4 Até 1980 trata-se de população recenseada. A partir de 1991, os dados são referentes à população residente.

${ }^{5}$ Cf. VEIGA, José Eli da. O Brasil rural ainda encontrou seu eixo de desenvolvimento. Estudos Avançados. v. 15, n. 43, 2001, p.109- 119. 
Tais questões deveriam lançar, ao menos, uma suspeita sobre o fatalismo demográfico, econômico, político e cultural que cerca a relação da sociedade brasileira com os territórios rurais: a ideia de que nele permanecem apenas os que não conseguem aventurar-se em direção às cidades e que seu declínio é somente uma questão de tempo.

Em cada momento da história, observam-se vários tipos de realidades rurais. “O 'rural' não se constitui como uma essência, imutável, que poderia ser encontrada em cada sociedade. Ao contrário, esta é uma categoria histórica, que se transforma" (WANDERLEY, 2000).

Existe um consenso na literatura internacional em torno de três aspectos básicos sobre o rural: a relação com a natureza, a importância das áreas não densamente povoadas e a dependência do sistema urbano (ABRAMOVAY, 2000). Assim, é necessário compreender os territórios rurais também a partir da relação rural-urbana, pois o rural não é definido por oposição e sim pela sua relação com as cidades.

Para qualquer município que tenha atividades com alguma expressão no meio rural, não é possível buscar o desenvolvimento urbano se ignorar o ambiente rural. Aliás, parte significativa dos municípios brasileiros tem desenvolvidas suas principais atividades econômicas na área rural. (MIRANDA, 2009, p. 13).

As relações entre rural e urbano são historicamente diferenciadas, mas nem sempre opostas ou antagônicas. Nos primeiros séculos da história brasileira, a ocupação do território se dava em redes de cidades dispersas, concentradas, sobretudo, na faixa litorânea do País, altamente dependentes das atividades agroexportadoras. Nesse momento da história do Brasil, o rural e o urbano eram dois polos em oposição, claramente delimitados e caracterizados pela dicotomia e contraposição. No urbano se concentravam o comércio e os serviços, e no rural concentravam-se as atividades agropastoris ligadas à natureza.

A partir dos anos 1930, com o Estado Novo, começam a se intensificar os processos de industrialização e de urbanização através de pesados investimentos nos sistemas de comunicações e transportes, que alteram o tempo e encurtam as distâncias. No campo normativo, o já citado Decreto-Lei no 311 de 1938, veio reforçar 
o entendimento das cidades como áreas urbanas, referindo-se apenas às sedes dos municípios, aquelas delimitadas por perímetros urbanos. O rural é considerado, por oposição, como a porção de terra própria para atividades agropecuárias e de reflorestamento, situada fora dos perímetros urbanos.

Nos anos 50, com a política desenvolvimentista de Juscelino Kubitschek, e mais tarde com o "milagre econômico" dos governos militares, o País assistiu a uma intensificação dos processos de industrialização, migração e urbanização. E o urbano passou a consumir mais intensamente as áreas rurais, encarecendo a infraestrutura e esterilizando o solo.

As pequenas cidades e os territórios rurais, situados fora do eixo de concentração do capital urbano-industrial, não assistiram a tal modernização, e permanecendo sob a dependência das exportações de produtos da agricultura, configuravam- se como cidades "arcaicas", "atrasadas", em contraposição aos centros urbano-industriais "modernos", “desenvolvidos".

Essas transformações econômicas definiram a visão que o Brasil tem de si mesmo, de país urbanizado que privilegiou, e ainda privilegia, as políticas e investimentos da economia urbana e industrial. Essa identidade de país urbano rapidamente se generalizou e adquiriu uma lógica própria pela qual se valoriza o "urbano" sobre o "rural". Com isso, o planejamento e os investimentos públicos orientam-se nitidamente para o modelo de expansão industrial das cidades e para o modelo produtivista do campo, o que parece ser clara evidencia da miopia de sucessivos governos para o desenvolvimento territorial do Brasil. (ZUQUIM, 2008, p. 1).

Também a agricultura experimentou a modernização, a partir dos anos 50, através de um sistema de crédito rural fortemente subsidiado, da implantação de indústrias de insumos agrícolas, e, mais tarde, da chamada "Revolução Verde" 6. Essa modernização substituiu pessoas por máquinas, o que resultou em grande êxodo rural. As cidades "modernas", que já não estavam preparadas para

${ }^{6}$ Segundo Del Grossi e Silva (2002): "revolução verde" é o processo de modernização da agricultura em que são utilizadas sementes melhoradas que respondem rapidamente ao uso de adubos químicos e de agrotóxicos, em operações geralmente mecanizadas. 
acompanhar o ritmo acelerado do desenvolvimento urbano-industrial, mostraram-se menos preparadas ainda para receber esses migrantes.

Nesse começo do processo de industrialização brasileira ocorreu o desmantelamento da economia familiar rural, devido à transferência de algumas atividades rurais para a indústria. Em paralelo, a fonte de renda monetária, que assegurava as famílias de pequenos produtores terem autarcia para praticar tanto atividades mercantis quanto atividades para autoconsumo, foi deslocada pela grande produção capitalista no campo - um movimento "natural" que se justifica, pois não pode haver desenvolvimento sem divisão do trabalho. Assim, a modernização da agricultura brasileira liberou de forma prematura parcelas importantes de mão de obra do campo para as cidades, e consequentemente houve a "proletarização formal" desses contingentes da população trabalhadora antes rural (RANGEL, 1979).

A industrialização brasileira se baseou, inicialmente, em bens de consumo, ou seja, tratava-se de uma indústria de "bases artesanais", portanto altamente empregadora de mão de obra. Porém, com o desenvolvimento da indústria pesada, sem o emprego intensivo de mão de obra, e as crises econômicas iniciadas na década de 1970, que cessavam a capacidade de absorção dessa mão de obra pelas indústrias, fizeram com que esses contingentes de mão de obra liberada pelo campo não encontrassem colocação, e, no "fim da linha", a migração rural-urbana terminava nas favelas das metrópoles, agravando ainda mais seus problemas estruturais (RANGEL, 1988).

Segundo WANDERLEY (2000), "não resta dúvida que as sociedades rurais tradicionais sofreram um intenso processo de transformações", tanto de ordem econômica, quanto na estrutura e na vida social local. O desenvolvimento industrial, concentrando-se nos espaços urbanos, reiterou a identificação entre atividade agrícola e rural, e as consequências se expressam no êxodo rural. Os primeiros a deixarem os territórios rurais são os trabalhadores rurais não agricultores, tornando o mundo rural um "gueto" de agricultores.

Portanto, o efeito mais mensurável do desdobramento da crise agrária iniciada nos anos 1960 foi o violento processo de urbanização, e o custo social decorrente dela, 
ou seja, o suprimento de serviços indispensáveis como transporte, saneamento, habitação, etc., "novos avatares dos velhos problemas agrários" (RANGEL, 1979, apud SILVA, 2000).

\begin{abstract}
A importância que assumiu a questão agrária nos anos 60, traduzida na figura do boia-fria com seus empregos temporários, transformouse, agora, numa crise urbana com milhares de desempregados permanentes. E o migrante rural continua a bater nas nossas metrópoles, num ir e vir sem destino, sem terra, sem saúde, sem organização, sem sindicato, homens e mulheres miseráveis sem nenhuma esperança, velhos sem aposentadoria e crianças sem futuro, que eu tenho chamado dos "sem-sem" nos meus trabalhos, também não por acaso. (SILVA, 2000, p. 36).
\end{abstract}

A partir da década de 70, em meio à crise urbana, processos mais complexos de organização espacial se configuravam, com o urbano avançando em direção às zonas rurais, normalmente sob a forma de assentamentos precários, caracterizando o domínio do urbano e a dependência do rural.

Este domínio do urbano sobre o mundo rural é reforçado a partir da Lei do Parcelamento do Solo Urbano (Lei no 6.766/1979) que intensificou a delimitação dos perímetros urbanos. Esta Lei definia que o parcelamento urbano só poderia ocorrer em glebas dentro do perímetro urbano ou de expansão urbana. Assim se assistiu a corrida por delimitações de perímetros, e mais tarde (e ainda hoje), o intenso processo de redelimitação desses perímetros, consumindo desenfreadamente as áreas rurais.

A dicotomia rural-urbana, nesse momento, não se apresentava entre rural e urbano, mas dentro do próprio espaço rural, onde as permanências e fragmentações criaram um rural "moderno" e um rural "tradicional". No urbano também se configurou essa dicotomia, que produzia igualmente o urbano e o suburbano.

A modernização da agricultura, aprofundando a dependência da produção agrícola aos insumos industriais e também aos mercados consumidores urbanos, moldou as políticas para esse setor a partir do modelo produtivista (WANDERLEY, 2000). Mas, a partir de meados dos anos 1980, o governo brasileiro abandona seu caráter regulador, priorizando as políticas de combate à inflação, e as políticas de 
apoio estatal perdem força. $\mathrm{O}$ modelo produtivista da modernização agrícola entra em crise, com destaque a três dimensões dessa crise:

1. Dimensão econômica: superprodução;

2. Dimensão social: redução da necessidade de força de trabalho ocupada nas atividades agrícolas; e

3. Dimensão ambiental: uso excessivo e indiscriminado de insumos químicos de origem industrial.

Dessa forma, um campo de confrontos nos territórios rurais brasileiros se instituiu, com três posições principais:

\section{Prioridade à destinação produtiva do rural;}

2. Associação do rural a uma melhor qualidade de vida, em que "os espaços rurais deixariam de ser prioritariamente produtivos para se tornarem espaços de consumo, voltados em especial para as atividades relacionadas às funções de residência e lazer" (WANDERLEY, 2000) se tornando assim, "patrimônio" da sociedade; e

3. O rural como parte integrante de um patrimônio ambiental, um bem coletivo.

Assim, a partir dos anos 80, um rural com "novas feições" foi percebido no Brasil:

Esse “Novo Rural" como vem sendo denominado, compõe-se de três grupos de atividades:

Uma agropecuária moderna, baseada em commodities e intimamente ligada às agroindústrias;

Um conjunto de atividades não-agrícolas, ligadas à moradia, ao lazer e a várias atividades industriais e de prestação de serviços;

Um conjunto de "novas" atividades agropecuárias, localizadas em nichos especiais de mercados. (DEL GROSSI; SILVA, 2002, p. 5).

O conjunto de atividades não-agrícolas à que se referem os autores abrange condomínios residenciais de alto e médio padrão (daqueles que fogem da insegurança das cidades), moradias populares (para os que encontram nessas áreas terras mais baratas), chácaras de recreio, spas, pesque-pagues, etc. 
O conjunto de "novas" atividades agropecuárias, localizadas em nichos especiais de mercados, refere-se à atividades como: produção de carnes especiais como rã, coelho, avestruz, etc., produção de polpa de frutas congeladas, alimentos prontos para consumo, floricultura, horticultura, fruticultura de mesa, etc. Essas atividades passam a integrar verdadeiras cadeias produtivas, envolvendo transformações agroindustriais, serviços pessoais e produtivos nos ramos de distribuição, comunicação e embalagens. Os autores colocam o termo "novas" entre aspas, pois essas atividades agropecuárias são, na verdade, seculares em nosso País, mas só a partir de meados dos anos 80 ganham importância econômica, pois antes eram atividades de "fundo de quintal", hobbies pessoais. Atividades que antes não eram comerciais, isto é, tinham apenas valor de uso e não de troca. (DEL GROSSI; SILVA, 2002).

Assim, a partir de meados dos anos 80, diante desta nova caracterização do mundo rural brasileiro, as alterações econômicas nas cadeias produtivas, no comércio e nos fluxos de capital produziram espaços cada vez mais periféricos ou marginais e a ocupação desses espaços se generalizou sem permitir claras delimitações (MIRANDA, 2009). A velha oposição entre rural e urbano perde sentido, tanto do ponto de vista econômico quanto social, e no espaço, o rural e o urbano se apresentam numa transição que se configura num continuum rural-urbano.

Hoje, o rural pode ser entendido como uma continuação da atividade econômica e espacial do urbano. Não se pode mais identificar as cidades apenas com a atividade industrial, nem os campos com a agricultura e a pecuária. O desenvolvimento rural e urbano começam a ser visto como complementares e alvos de políticas públicas interdependentes. Pode-se dizer que a diferença entre rural e urbano é cada vez menos importante. (ZUQUIM, 2008, p. 4).

É oportuno destacar que essa configuração espacial do continuum rural-urbano não é universal. Em muitos países, principalmente os em desenvolvimento, há vastas áreas onde a industrialização da agricultura, tampouco o transbordamento do urbano para o rural, não se efetivou. Mas o que é importante destacar é que geograficamente pode não existir continuum, mas econômica e socialmente o urbano 
e o rural se configuram como complementares, e suas diferenças passam a ser cada vez menos importantes para o desenvolvimento territorial do todo.

O que fica claro é que o mundo rural não pode mais ser visto como um espaço caracterizado por usos do solo ligados à atividades agropastoris apenas. Soma-se a seus velhos atributos - a produção agropecuária, de matéria-prima e principalmente a produção de alimentos - o rural como espaço de consumo, como patrimônio ambiental e ainda como espaço de preservação do patrimônio genético, da cultura local, etc. Mas o rural ainda pode ser conceituado como um espaço caracterizado por dispersão, baixa densidade, diversidade de processos, continuidades e descontinuidades, principalmente em se tratando de Brasil, um país com dimensões continentais, que apresenta enorme diversidade de configurações sócio-espaciais.

O urbano também não pode mais ser caracterizado como um espaço de comércio e serviços apenas. Deve sim ser associado à projeção espacial do modo de produção capitalista e de sua divisão social do trabalho, que hoje vai para além do próprio urbano. "O urbano tornou-se um modo de vida e isto destrói a velha dicotomia campo-cidade" (informação verbal ${ }^{7}$ ). Nesse sentido, a noção de urbano e urbanização está intimamente ligada à ideia de qualificação, de provisão de serviços e de infraestrutura, de difusão de um sistema de atitudes e de condutas.

Isto faz do urbano produtor de uma cultura, que amplia a noção de cidadania, incluindo-se aí direitos sociais urbanos. É a ideia do direito à cidade, ou seja, a cidade como valor de uso, onde todos os habitantes, sejam rurais ou urbanos, tenham acesso aos custos e aos benefícios da urbanização. Assim, o urbano pode e deve "transbordar" sobre o mundo rural, mas sem transformá-lo num espaço suburbano.

7 Informação fornecida pela Profa. Dra. Maria Adélia Aparecida de Souza, durante curso da disciplina: Espaço Geográfico, Território e Sociedade: Revisitando o Método Geográfico, Faculdade de Filosofia, Letras e Ciências Humanas, Universidade de São Paulo (FFLCH/USP), $1^{\circ}$ semestre de 2011. 


\subsection{Desenvolvimento Rural}

Partimos do entendimento de que o mundo rural não pode mais ser visto como um espaço caracterizado por usos do solo ligados às atividades agropastoris apenas. O urbano também não pode mais ser caracterizado como um espaço exclusivo de comércio, serviços ou indústria. Não são patamares populacionais, densidade econômica, capacidade de geração de empregos ou a existência de um mínimo de serviços de infraestrutura que definem se uma área é rural ou urbana. Na verdade, o que define os territórios rurais são as relações sociais e econômicas que o uso e ocupação do solo revelam, através das técnicas, dos meios de produção, de poderes e de necessidades que esse território concentra. Assim, o que fica claro é que:

Ruralidade é um conceito de natureza territorial e não-setorial e o mesmo se aplica à noção de urbano. As cidades não são definidas pela indústria nem o campo pela agricultura. [...] A implicação é que em vez de uma definição setorial de áreas rurais, é necessário uma definição espacial. Portanto, a unidade de análise não são os sistemas agrários nem os sistemas alimentares, mas as economias regionais [...]. Em outras palavras, desenvolvimento rural é um conceito espacial e multissetorial e a agricultura é parte dele. (ABRAMOVAY, 2000, p. 6, grifos do autor).

Mas o que é desenvolvimento? As ideias gerais sobre desenvolvimento no corpo teórico da economia e da sociologia quase sempre são pautadas pela ideia restrita de crescimento econômico. Até o século XIX, prevalecia a ideia de desenvolvimento como evolução e progresso, passando pela ideia de utopia, que no século XX é substituída por crescimento. Pelo fato de o dinamismo econômico ser tratado como sinônimo de melhora dos indicadores sociais, a ideia de crescimento passa a ser identificada com desenvolvimento econômico. Mais recentemente são incorporados ao conceito os indicadores de bem-estar ou de desenvolvimento humano 
(expressos pelo $\mathrm{IDH}^{8}$ ) e os indicadores de sustentabilidade ambiental ou desenvolvimento sustentável (FAVARETO, 20069, apud KAGEYAMA, 2008).

Não existe consenso sequer entre os especialistas sobre o significado da palavra desenvolvimento. Na verdade, trata-se de um termo que se generalizou nas ciências sociais contemporâneas após a Segunda Guerra Mundial e que, frequentemente, até hoje, é confundido com crescimento econômico. O prêmio Nobel de economia de 1993, Amartya Sen, define desenvolvimento como o processo de ampliação das capacidades dos indivíduos de fazerem escolhas. O que surpreende nesta definição é que ela não se concentra imediatamente em fatores materiais, em indicadores econômicos, mas na ampliação do horizonte social da vida das pessoas. A base material do processo de desenvolvimento é absolutamente decisiva, sem dúvida. Mas ela deve ser encarada como um meio e não como um fim. Não é óbvio que o crescimento econômico, por exemplo, se associe de maneira automática a um processo de desenvolvimento. É deste tipo de reflexão que resultou a preocupação contemporânea com índices de desenvolvimento social que vão muito além da capacidade produtiva de uma sociedade: a questão é saber se o aumento desta capacidade produtiva traz bem-estar. Mais que isso, trata-se de saber se ela melhora a qualidade de vida em comum, a confiança das pessoas no futuro e sobretudo sua possibilidade de levar adiante iniciativas pelas quais possam realizar seu potencial e contribuir de maneira valorizada para a vida social. É por isso que Sen sintetiza sua reflexão dizendo que desenvolvimento é "poder contar com a ajuda de meus amigos": não se trata de restringir a ambição contida na palavra desenvolvimento, mas ao contrário de impedir que ela se submeta aos puros imperativos do crescimento econômico. (ABRAMOVAY, 2009, p. 76).

Essa distinção entre crescimento econômico e desenvolvimento, introduz a necessidade de enfoques multidimensionais nas discussões acerca do desenvolvimento rural, e culmina no abandono do horizonte setorial (agricultura como setor único e o agricultor como sujeito social exclusivo) - o que aponta para duas consequências: uma operacional, em que a ruralidade se torna uma categoria territorial, e outra teórica "que define o território a partir das interações sociais que se

8 IDH: índice de desenvolvimento humano. O índice foi desenvolvido em 1990 pelos economistas Amartya Sen e Mahbub ul Haq, e é utilizado desde 1993 pelo Programa das Nações Unidas para o Desenvolvimento, no seu relatório anual de classificação de seus países membros. O índice considera dados de expectativa de vida, educação e PIB (produto interno bruto) per capita. $\mathrm{O}$ IDH também é usado por organizações locais ou empresas para medir o desenvolvimento de entidades subnacionais como estados, cidades, aldeias, etc. (IDH, n.p.).

${ }^{9}$ Cf. FAVARETO, Arilson da Silva. Paradigmas do desenvolvimento rural em questão - do agrário ao territorial. Tese (Doutorado). São Paulo: FEA/ USP/ Procam, 2006. 
produzem no interior de certos limites físicos, e não por esses próprios limites" (ABRAMOVAY, 2006 apud KAGEYAMA, 2008).

As funções convencionais de fornecimento de matérias-primas e mãode-obra para o crescimento econômico são cada vez menos importante diante dos próprios atributos territoriais que definem, conceitualmente, a ruralidade [...]: uma certa relação com a natureza (em que a biodiversidade e a paisagem natural aparecem como trunfos e não como obstáculos ao desenvolvimento), uma certa relação com as cidades (de onde vem parte crescente das rendas das populações rurais) e uma certa relação dos habitantes entre si (que pode ser definida pela economia da proximidade, por um conjunto de laços sociais que valorizam relações diretas de interconhecimento): estas características oferecem perspectivas promissoras ao processo de desenvolvimento.

Aproveitá-las supõe, antes de tudo, que se encare o meio rural como o espaço de atividades variadas reunindo uma multiplicidade de atores sociais e não apenas como terreno de onde vão sair produtos agropecuários [...]. Se, [...] [o meio rural] é visto como a base para a expansão de inúmeras atividades - baseadas em laços sociais que os indivíduos e as organizações foram capazes de construir - daí vai decorrer uma visão do território brasileiro que recusa às metrópoles o lugar exclusivo de horizonte promissor para as novas gerações. (ABRAMOVAY, 2009, p.15).

Portanto, o território é entendido muito além de seus atributos naturais, dos custos de transportes e de comunicações. É mais que simples base física para as relações entre indivíduos ou a estrutura espacial da produção e reprodução social. Um território representa uma trama de vínculos com raízes históricas, configurações políticas e identidades que revelam relações de poder. Não há território sem uma trama de relações e práticas sociais. Assim, o território está intimamente relacionado a como as pessoas usam a terra, como organizam o espaço e como dão significado ao lugar.

A ruralidade não é uma etapa do desenvolvimento social a ser superada com o avanço do progresso e da urbanização. Ela é e será cada vez mais um valor para as sociedades contemporâneas. É em torno deste valor - e não somente de suas atividades econômicas setoriais - que se procuraram aqui as características mais gerais do meio rural [...]. A importância entre nós da agricultura não deve impedir uma definição territorial do desenvolvimento e do meio rural. (ABRAMOVAY, 2000, p. 26- 27, grifo do autor). 
O desenvolvimento rural vem substituindo, enquanto paradigma, a modernização da agricultura, e passa a buscar um novo modelo para o setor agrícola com novos objetivos como: a produção de bens públicos (paisagens), sinergias com os ecossistemas locais, maior valorização das economias de escopo em relação às de escala e a pluriatividade ${ }^{10}$ das famílias rurais. Assim, o desenvolvimento rural se apresenta como um processo "multi-nível, multi-atores e multifacetado" e o espaço rural transforma-se numa "multiplicidade de espaços" no interior de uma mesma área geográfica, cada um com sua lógica, suas instituições e suas redes de sujeitos sociais (KAGEYAMA, 2008).

As características fundamentais das novas estratégias de desenvolvimento rural são a diversidade - de atores envolvidos, de atividades empreendidas e de padrões de motivação emergentes - e a multifuncionalidade, que implica a reconfiguração no uso dos recursos como terra, trabalho, conhecimento e natureza (reconfiguração que se opera no interior das unidades agrícolas e entre a agricultura e outras atividades rurais). (KAGEYAMA, 2008, p. 70 , grifos da autora).

Visto que é necessário compreender os territórios rurais também a partir da relação rural-urbana, o mesmo vale para o desenvolvimento rural, que se apresenta como um processo "multifacetado", em que o espaço rural transforma-se numa "multiplicidade de espaços". Assim, a análise do desenvolvimento rural deve contemplar também o desenvolvimento da rede urbana local e regional, para que a integração rural-urbana se manifeste em sua plenitude. Portanto:

Regiões com redes urbanas bem distribuídas, recursos territoriais adequados e mercados que favoreçam a pluriatividade devem apresentar um desenvolvimento rural dinâmico e integrado, em contraste com áreas isoladas, sem privilégios naturais e sem instituições adequadas.

Os efeitos do tipo e do grau de urbanização sobre o desenvolvimento rural não advém simplesmente da concentração populacional em si, mas dos fenômenos econômicos que podem estar refletidos, por exemplo, na densidade demográfica. Os efeitos de aglomeração,

10 Pluriatividade: combinação de atividades agrícolas e não-agrícolas no interior da mesma família extensa. Pode ainda ser pluriatividade a combinação de atividade agrícola no próprio negócio com outra atividade agrícola como assalariado em outros locais. (DEL GROSSI; SILVA, 2002, v. I, p. 51- 52). 
especialização e diversificação de mercados, o tamanho e a proximidade dos mercados de insumos, as redes de informação e transportes, as economias externas de escala, são alguns dos elementos que favorecem o desenvolvimento local e, por extensão, $\mathrm{o}$ desenvolvimento rural do entorno. (KAGEYAMA, 2008, p. 76- 77).

Mas a integração rural-urbana no Brasil é pouco estimulada por nossos governantes e as áreas rurais são tratadas, historicamente, como estoque de área a ser urbanizada, sem se considerar sua adequação ao uso agropecuário, a necessidade de preservação ambiental, e principalmente a baixa capacidade de suporte a determinados usos exclusivamente urbanos. Há também a falta de condições do poder público em atender demandas por serviços públicos e infraestruturas decorrentes da urbanização nesses espaços (MIRANDA, 2002).

Ao invés de se pensar (e implementar) um modelo de integração rural-urbana, o que vigora é a ideia de que o urbano substitua o rural, o que resulta na transformação do rural num espaço suburbano, sem infraestrutura, sem serviços públicos, sem cidadania. Assim, na medida em que a urbanização se expande e assume uma forma cada vez mais espraiada, os territórios rurais tornam-se objeto de interesses diversos e de conflitos cada vez maiores. E as áreas rurais mais próximas aos centros urbanos tendem a ser as mais drasticamente atingidas por esses processos de urbanização, ou, melhor, de suburbanização. Essas áreas, chamadas de transição rural-urbana, podem ser conceituadas como:

[...] espaços plurifuncionais, em que coexistem características e usos do solo tanto urbanos quanto rurais - presença dispersa e fragmentada de usos e ausência de estrutura urbana coerente que proporcione unidade espacial, submetidos a profundas transformações econômicas, sociais e físicas, com uma dinâmica estreitamente vinculada à presença próxima de um núcleo urbano.

[...] são lócus de problemas decorrentes das diferentes dinâmicas da urbanização (favelização, especulação imobiliária, segregação espacial, turismo rural, migrações pendulares, crescimento da economia informal, etc.). (MIRANDA, 2009, p. 8- 9).

As áreas de transição rural-urbana, tampouco as áreas rurais mais distantes dos centros urbanos, não são (nem nunca foram) objeto direto do planejamento territorial ou urbano brasileiro, mas são fortemente impactadas pelas políticas implementadas nas cidades, ou melhor, em suas áreas urbanizadas. E as formas de regulação pública 
dos espaços tanto urbanos quanto rurais se tornam quase sempre bastante problemáticas.

Uma das explicações sobre por que o foco do planejamento urbano brasileiro vem se mantendo nas áreas urbanizadas das cidades é dada pela prevalência das matrizes teóricas dos modelos centro-periferia para explicar os processos de expansão urbana (MIRANDA, 2009). Esse modelo centro-periferia, ou ainda modernidade-pobreza, é o que caracteriza historicamente a formação das aglomerações urbanas brasileiras, sempre com atenção ao centro das cidades, onde as elites vivem, ou seja, a cidade formal (MARICATO, 2000).

O processo de expansão urbana, pautado principalmente pelos interesses do mercado e das elites, se deu através da expansão extensiva, fragmentada, descontínua, espraiada e desestruturada das aglomerações urbanas. O resultado foi o transbordamento dos assentamentos precários para as áreas fora dos centros urbanizados, e ainda a distribuição desigual dos bens e serviços públicos no território. Assim, ocorreu a formação de aglomerações urbanas densas e polarizadas: centro moderno ou cidade formal versus periferia pobre ou cidade informal. Nessa lógica, as áreas rurais são encaradas como estoque de áreas a serem urbanizadas, sem qualquer consideração às suas características territoriais como seus usos históricos, sua população e suas práticas sociais.

Dessa forma, a cidade é produzida segundo interesses das elites dominantes e do mercado imobiliário. Em paralelo, o planejamento urbano segue o mesmo caminho, e acaba por não enfrentar de fato as questões sociais decorrentes dos processos de expansão urbana, mesmo tendo instrumentos urbanísticos excelentes como opções para o enfrentamento dessas questões, tais como Planos Diretores, Leis de Uso e Ocupação do Solo e outros aparatos regulatórios.

A história do planejamento urbano no Brasil mostra a existência de um pântano entre sua retórica e sua prática, já que estava imerso na base fundante marcada por contradições: direitos universais, normatividade cidadã - no texto e no discurso - versus cooptação, favor, discriminação e desigualdade - na prática da gestão urbana. (MARICATO, 2000, p. 135). 
Assim, o domínio das elites na história do planejamento urbano brasileiro, privilegiando a cidade formal, reafirmando e reproduzindo desigualdades e privilégios (MARICATO, 2000), é marcado pela distância entre o discurso e seus planos e a realidade das cidades brasileiras.

Até 1930, o planejamento urbano brasileiro era executado através de planos de "melhoramentos e embelezamentos" 11, que na maior parte dos casos se limitavam a intervenções "higienistas" pontuais, no centro das cidades. Já em 1930, é inaugurada a fase dos planos de conjunto. No discurso pretendia-se abordar a cidade toda, mas as intervenções continuaram se concentrando apenas nas áreas centrais das cidades é o “planejamento-discurso” (VILLAÇA, 1999), que perdura até meados dos anos 60.

O distanciamento entre os planos e a realidade das cidades atinge seu apogeu com os "superplanos" ou "planos de desenvolvimento integrado", entre 1965 e 1971, que eram planos altamente tecnocratas elaborados por especialistas de escritórios privados - e por isso mesmo tão distante das realidades das cidades. Esses planos, com foco nas cidades médias e grandes, abordavam diversas faces do território, como o viés ambiental, o rural, etc., que se materializaram em coeficientes de ocupação do solo, usos admitidos, zoneamentos, etc. Este período é marcado também pelo nascimento da "indústria” dos Planos Diretores.

A partir dos anos 70, surgiram os "planos sem mapas", contendo apenas objetivos, políticas e diretrizes (VILLAÇA, 1999). Já os anos 80 foram marcados pela tentativa de criação dos planos políticos, buscando a discussão tanto técnica quanto política da cidade real, afinal, politicamente, o País saía do período de ditadura militar e entrava para a democracia. E exatamente durante o processo constituinte, ocorre uma articulação nacional em torno do Movimento Nacional pela Reforma Urbana, que teve papel fundamental na aprovação do capítulo da Política Urbana da Constituição de 1988, com destaque a garantia da função social da propriedade urbana e o conceito de direito à cidade.

11 "Segundo Villaça, foi sob a égide do embelezamento que nasceu o planejamento urbano brasileiro.” (MARICATO, 2000, p. 137). 
Nos anos 90, vivemos a safra de planos estratégicos, baseados nos princípios de competitividade entre os municípios, privatizações e desburocratização. $\mathrm{O}$ resultado foi a conversão de direitos em mercadorias e de cidadãos em clientes. Nos anos 2000, generalizaram-se os planos tipo "acupuntura urbana", ou "intervenção cirúrgica", baseados na ideia de que pontos estratégicos alavancariam o desenvolvimento da cidade ou de regiões dela.

Em 2001, a aprovação do Estatuto da Cidade, veio regulamentar a Política Urbana Brasileira (Artigos 182 e 183 da Carta de 1988), e uma nova forma de olhar a cidade se instituiu. Foi estabelecida uma nova ordem jurídico-urbanística no País, baseada no direito à moradia, na função social da cidade e da propriedade e no planejamento de gestão do solo urbano como instrumento de estratégias de inclusão territorial (ROLNIK, 2006).

O Estatuto definiu que o Plano Diretor Participativo ${ }^{12}$ deve abranger o território municipal como um todo ${ }^{13}$, tanto suas áreas urbanas como as rurais. Nessa concepção, a cidade se confunde com o município, ou seja, a cidade compreende todo o município, é a cidade real, não mais apenas suas áreas urbanas. A novidade é a ideia de que se deve tratar o território onde a sociedade se assenta, qual seja: rural $e$ urbano, para trabalhar seu desenvolvimento territorial. E aqui podemos dizer que passamos do planejamento urbano para o planejamento territorial, ao menos na teoria.

Apesar do texto da Lei do Estatuto da Cidade não fazer muitas referências aos territórios rurais, ele não os ignora. Inclusive é bastante relevante o artigo $2^{\circ}$, que traz as diretrizes gerais segundo as quais a Política Urbana deve ser implementada:

Art. $2^{\circ}$ A política urbana tem por objetivo ordenar o pleno desenvolvimento das funções sociais da cidade e da propriedade urbana, mediante as seguintes diretrizes gerais:

$[\ldots]$

12 Segundo a Constituição Federal, artigo 182, § $1^{\text {o: }}$ o plano diretor, aprovado pela Câmara Municipal, é obrigatório para cidades com mais de vinte mil habitantes, e é o instrumento básico da política de desenvolvimento e de expansão urbana. (BRASIL, 1988).

${ }^{13}$ Estatuto da Cidade (Lei Federal no 10.257/2001) Cap. III, Art. 40, § 2: O plano diretor deverá englobar o território do Município como um todo (BRASIL, 2001). 
VII - integração e complementaridade entre as atividades urbanas e rurais, tendo em vista o desenvolvimento socioeconômico do Município e do território sob sua área de influência;

[...]. (BRASIL, Lei $\mathrm{n}^{\mathrm{o}}$ 10.257, de 10 de julho de 2001. Estatuto da Cidade).

Esta ideia de estimular a integração e complementaridade entre as atividades urbanas e rurais nos mostra o entendimento da Lei de que o mundo rural existe e não está fadado ao fim. Pelo contrário, ele tem um papel complementar ao urbano.

[...] se o meio rural for apenas a expressão, sempre minguada, do que vai restando das concentrações urbanas, ele se credencia, no máximo, a receber políticas sociais que compensem sua inevitável decadência e pobreza. Se, ao contrário, as regiões rurais tiverem a capacidade de preencher funções necessárias a seus próprios habitantes e também às cidades - mas que estas próprias não podem produzir - então a noção de desenvolvimento poderá ser aplicada ao meio rural. (ABRAMOVAY, 2000, p. 3, grifos do autor).

Emerge, então, a importância de se compreender os territórios rurais e suas especificidades, para que se elaboram políticas públicas próprias para esses territórios. Afinal, muitas medidas empregadas nos territórios rurais são derivadas da visão e das práticas urbanas, e por isso mesmo, estão fadadas ao fracasso. Assim, é necessário ultrapassar os limites convencionais físico-territoriais e passar a lidar com processos sociais, econômicos, com a lógica das cadeias produtivas e dos circuitos regionais agroalimentares.

Há várias possibilidades de incrementar a interação rural-urbana e de promover sinergias entre suas atividades. O Plano Diretor pode e deve tornar-se uma grande ferramenta de planejamento territorial. E mais: associar outras políticas, como a de Segurança Alimentar e Nutricional, por exemplo, ao Plano Diretor configura-se como um incremento para a integração rural-urbana, e consequentemente para o desenvolvimento territorial do País.

Assim, o que fica é que devemos sim pensar em formas de estender os serviços e direitos relativos à cidadania aos territórios rurais, sem que para isso, esses territórios sejam transformados em áreas suburbanas. E aqui o conceito de cidadania remete aos direitos fundamentais humanos, ao direito à cidade, ao "desenvolvimento 
como o processo de ampliação das capacidades dos indivíduos de fazerem escolhas", como definido por Sen.

\subsection{Sujeitos Sociais Rurais.}

A construção de um território se dá a partir da trama de relações sociais que atores ou sujeitos sociais imprimem através de suas características socioculturais vínculos com raízes históricas, configurações políticas e identidades - em determinados espaços. Não há território sem uma trama de relações e práticas sociais. Assim, o território está intimamente relacionado a como os sujeitos sociais usam a terra, como organizam o espaço e como dão significado - identidade, pertencimento - ao lugar.

Podemos identificar nos territórios rurais brasileiros hoje diversos sujeitos sociais: os chamados agricultores familiares - agricultores cooperados/ associados ou não, assentados de projetos de Reforma Agrária, arrendatários, parceiros, comunidades tradicionais (como índios, quilombolas, caiçaras, etc.). Há ainda pessoas que apenas moram nas áreas rurais ${ }^{14}$ (como aposentados, por exemplo), outras ocupadas somente em atividades não-agrícolas. Há também o agronegócio, que também pode ser chamado de agricultura patronal, agricultores empresariais, oligarquias rurais, grandes produtores ou agricultores capitalistas.

Isto posto, faz-se necessário o aprofundamento referente aos sujeitos sociais concernentes aos territórios que são foco de nossa pesquisa: os pobres rurais. Assim, será necessária uma rápida contextualização do agronegócio e dos agricultores familiares, para delimitarmos com maior clareza os sujeitos sociais foco de nossa pesquisa.

${ }^{14}$ Segundo Wanderley (2000), a residência no meio rural tem se tornado cada vez mais uma escolha. 
A origem do termo agronegócio veio importada do modelo norte-americano, em meados da década de 1990, e trouxe consigo a carga ideológica daquele modelo: atividades agropecuárias em grande escala desenvolvidas em grandes extensões de terra, ligadas a uma cadeia de negócios, que envolve produtores rurais, negócios da indústria, comércio de insumos e comercialização da produção. Assim, o agronegócio pode ser definido como:

[...] o conjunto de negócios relacionados à agricultura do ponto de vista econômico. É dividido em três partes:

a) a de negócios agropecuários propriamente ditos (ou de "dentro da porteira") que representam os produtores rurais, sejam eles pequenos, médios ou grandes produtores;

b) os negócios à montante (ou "da pré-porteira") aos da agropecuária, representados pela indústria e pelo comércio que fornecem insumos para os negócios agropecuários;

c) negócios à jusante (ou "pós-porteira") que são aqueles negócios que compram os produtos agropecuários, os beneficiam, os transportam e os vendem para os consumidores finais. (DIEESE; NEAD; MDA, 2011. p. 277).

No Brasil, o conceito surgiu nos anos 1980, com a expressão "Complexos Agroindustriais", que evoluiu mais tarde para "agronegócio". O termo se materializou porque as grandes empresas do setor patronal rural buscavam recriar uma imagem do setor, agora associada a técnicas de produção intensiva e de escala, aumento de produção e produtividade. A ideia era se contrapor à lógica latifundista (grandes extensões de terras utilizadas apenas como reserva de valor), bem como à produção de subsistência e às atividades agropecuárias de menor escala (SAUER, 2008). Assim, o agronegócio foi um termo apropriado por uma classe e cunhado num determinado contexto político-ideológico.

Já a categoria Agricultura Familiar pode ser definida pela gestão familiar da unidade de produção e pelo tipo de trabalho utilizado no estabelecimento. São as relações sociais de produção que caracterizam o agricultor familiar (BUAINAIN; GUANZIROLI; SABBATO, 2010). Suas principais características são:

1. Utiliza majoritariamente mão de obra familiar;

2. Exerce a gestão do empreendimento de forma direta; 
3. Geralmente estabelecem relações socioculturais e econômicas com os espaços local e regional.

A visão dominante da sociedade brasileira sobre a Agricultura Familiar está fortemente vinculada à ideia de pequena produção, como unidade de subsistência produtora de itens da alimentação básica, que comercializa excedentes nos mercados locais e se insere no mercado de trabalho rural como trabalhador temporário. Mas:

Nem todos os agricultores familiares são de subsistência; uma parcela significativa (em torno de 50\%) é voltada para o mercado, ou seja, são empreendedores comerciais, e nem todos os grandes fazendeiros [...] são latifundiários absenteístas. (BUAINAIN; GUANZIROLI; SABBATO, 2010, p. 4).

O termo Agricultura Familiar também veio importado do modelo norteamericano nos anos 1990. A intenção de seu uso era romper com as noções de pequena produção, produção de subsistência, baixa-produtividade ou ineficiência e não inserção no mercado. A incorporação desse conceito ajudava a agregar vários sujeitos sociais como assentados de projetos de Reforma Agrária, arrendatários, parceiros, entre outros.

A criação do PRONAF (Programa Nacional de Fortalecimento da Agricultura Familiar ${ }^{15}$ ), em 1995/96, veio legitimar o conceito de Agricultura Familiar pelo Estado, sendo o primeiro programa governamental voltado para esse segmento social. Por fim, a Lei da Agricultura Familiar e Empreendimentos Familiares Rurais (Lei $\mathrm{n}^{\mathrm{o}}$ 11.326, de 24 de julho de 2006), vem para sedimentar a legitimação do conceito e ainda demonstrar a intenção do governo em fortalecer esses sujeitos sociais.

Na esteira da intenção do governo em fortalecer a Agricultura Familiar, o Censo Agropecuário 2006: Agricultura Familiar - Primeiros Resultados (IBGE, 2009a)

15 O PRONAF foi criado em 1995 como uma linha de crédito e suas regras foram estipuladas pelo Conselho Monetário Nacional e pelo Banco Central. Em 1996, o programa passa a integrar o Orçamento Geral da União, agora com status de programa governamental, via Decreto $n^{\circ} 1.946$, de 28 de junho de 1996. (BRASIL, 1996). 
realizado pelo IBGE em parceria com o MDA (Ministério do Desenvolvimento Agrário), demonstrou a importância da Agricultura Familiar brasileira (Tabela 2).

Tabela 2 - Caracterização dos estabelecimentos agropecuários, de acordo com a classificação de Agricultura Familiar, segundo a Lei no 11.326, Brasil, 2006.

\begin{tabular}{lllll}
\hline \multirow{2}{*}{ Características } & \multicolumn{2}{l}{ Agricultura Familiar } & \multicolumn{2}{l}{ Não familiar } \\
& valor & $(\%)$ & valor & $(\%)$ \\
\hline Número de estabelecimentos & 4.367 .902 & $84 \%$ & 807.587 & $16 \%$ \\
Área (milhões ha) & 80,3 & $24 \%$ & 249,7 & $76 \%$ \\
Mão de obra (milhões de & 12,3 & $74 \%$ & 4,2 & $26 \%$ \\
pessoas) & 54,4 & $38 \%$ & 89,5 & $62 \%$ \\
Valor da produção (R\$ bilhões) & 51,3 & $34 \%$ & 80,5 & $66 \%$ \\
Receita (R\$ Bilhões) & 41,3 \\
\hline
\end{tabular}

Fonte: DEL GROSSI; MARQUES, 2012, p.152.

Os dados nos mostram que a distribuição da propriedade da terra continua extremamente concentrada no Brasil, mas destaca um papel importante da Agricultura Familiar no total da produção, principalmente na produção doméstica. Ou seja, mesmo com menos área, é a Agricultura Familiar que produz alimentos no Brasil.

Os resultados [...] também confirmaram a importância da Agricultura Familiar na garantia da segurança alimentar [...] abastecendo os produtos típicos de consumo no mercado interno: $87 \%$ da produção de mandioca, $70 \%$ da produção de feijão, $59 \%$ do rebanho de suínos, $50 \%$ do rebanho de aves e $58 \%$ da produção de leite. (DEL GROSSI; MARQUES, 2012, p.153).

Uma análise dos resultados do Censo Agropecuário do IBGE de 1995/96, junto ao estudo denominado "Novo Retrato da Agricultura Familiar: o Brasil Redescoberto" (2000), elaborado pelo Projeto de Cooperação Técnica FAO (Organização das Nações Unidas para Alimentação e Agricultura)/INCRA (Instituto Nacional de Colonização e Reforma Agrária) ${ }^{16}$, sugere uma tipologia que inclui três

${ }_{16}$ O Projeto de Cooperação Técnica INCRA/ FAO atuou entre 1994 e 1999, sob a Coordenação de Carlos Enrique Guanziroli (FAO) e Silvia Elizabeth de C. S. Cardim (INCRA). O Projeto produziu um primeiro estudo (1994) que se constituiu em um 
tipos de agricultor familiar no Brasil: um primeiro tipo "family farmers" (do modelo americano), que possuem tamanho para desenvolver uma agricultura empresarial, com escala de produção e se integram em cadeias típicas do agronegócio (produtores gaúchos e paranaenses de soja e trigo, produtores de leite de Minas, produtores catarinenses de milho e aves, produtores de frutas no Nordeste, etc.); um segundo tipo que se restringe a participar de cadeias de produtos alimentares; e o terceiro tipo propriamente de subsistência, aqueles caracterizados como "pequenos produtores".

Essa tipologia se baseia na metodologia adotada pela pesquisa INCRA/ FAO, "que caracteriza e diferencia um agricultor familiar de um patronal em função das relações sociais de produção", e não considera o tamanho do estabelecimento ou o valor de receita, como adotam alguns países. O tamanho da área pode nos induzir a acreditar que se trata de "pequeno produtor", mas essa classificação pode "camuflar relações sociais diferentes (pequeno em área, mas patronal, ou grande em área, mas familiar)" (BUAINAIN; GUANZIROLI; SABBATO, 2010).

É importante salientar que os agricultores familiares, independente da tipologia em que se enquadrem, são os que mais contribuem para a "interiorização do desenvolvimento rural", viabilizando os comércios locais e as aglomerações ruralurbanas, pois tendem a "fincar raízes" (BUAINAIN; GUANZIROLI; SABBATO, 2010).

Os dados do Censo Agropecuário e suas análises nos revelam a força econômica e social da Agricultura Familiar brasileira, além de sua heterogeneidade intra e interregiões. Mas a pobreza rural permanece em destaque, principalmente em relação aquele terceiro tipo - os agricultores familiares propriamente de subsistência, os "pequenos produtores".

importante referencial para classificação quantitativa dos estabelecimentos considerados familiares. A partir desse mesmo trabalho nasceu a separação entre agricultores patronais e agricultores familiares. Ainda produziu outros importantes estudos como: INCRA/ FAO. Perfil da Agricultura Familiar no Brasil: dossiê estatístico. Brasília: INCRA/ FAO, 1996; e Novo retrato da Agricultura Familiar: o Brasil redescoberto. Brasília: INCRA/ FAO, 2000. 
A alteração desse quadro de pobreza exige o acesso à terra, à infraestrutura (água, eletrificação, estradas, habitação), às políticas agrícola e de seguridade social (educação, saúde e assistência social).

Assim, terá maior destaque nesta pesquisa exatamente este terceiro tipo de agricultor familiar, ou ainda os minifundiários, assentados de projetos de Reforma Agrária, parceiros e arrendatários ${ }^{17}$. São esses sujeitos sociais que se encontram à margem do sistema, vivendo na pobreza, e que por isso mesmo deveriam ser o público prioritário das políticas públicas do mundo rural. Trata-se de assegurar condições para melhorar aquelas habilitações e capacidades desses sujeitos sociais, destacadas por Amartya Sen.

O minifúndio é definido pelo Estatuto da Terra, marco legal originário da política agrária brasileira, como "o imóvel rural de área e possibilidades inferiores às da propriedade familiar" (Art. $4^{\circ}$ inciso IV, Lei $n^{\circ} 4.504 / 64$ ). Isto significa que a área do minifúndio não é suficiente para garantir quaisquer condições de reprodução de forma autônoma a uma família de agricultores. "De acordo com os dados do Sistema Nacional de Cadastro Rural (SNCR) do INCRA, dos 5,18 milhões de imóveis rurais existentes [em 2006], 3,37 milhões são minifúndios" (IPEA, 2010, p. 231).

Importante destacar também os agricultores familiares com acesso precário à terra. Esses agricultores, chamados de "precários", são definidos pela reunião das categorias "produtor sem área" 18, "parceiro" e "arrendatário" (IPEA, 2010) estabelecidas pelo Censo Agropecuário 2006 (tabela 3).

17 Segundo o Censo Agropecuário 2006: Brasil Grandes Regiões e Unidades da Federação (IBGE, 2009b), os parceiros são aqueles produtores que exploram propriedades de terceiros mediante pagamento de parte da produção (meia, terça, quarta, etc.), previamente ajustado entre as partes; os arrendatários são aqueles produtores que exploram propriedades de terceiros mediante pagamento de uma quantia fixa, em dinheiro ou sua equivalência em produtos também previamente ajustado entre as partes. (IBGE, 2009b).

18 "Produtor sem área" é o empregado de um estabelecimento agropecuário que mantém atividade de criação/produção agropecuária sob sua administração. É o produtorempregado sem área. (IBGE, 2009b, p. 32- 33). Integram os "produtores sem área" extrativistas, produtores de mel ou produtores com produção em áreas temporárias tais como produtores em leitos de rio na época da vazante, produtores em faixa de proteção ou acostamento de estradas, produtores de carvão vegetal que possuem os fornos e trabalham 

2006.

Tabela 3 - Estabelecimentos sob condições precárias por grandes regiões, Brasil,

\begin{tabular}{lll}
\hline Região & $\begin{array}{l}\text { Estabelecimentos } \\
\mathrm{n}^{\mathrm{o}}\end{array}$ & $(\%)$ \\
\hline Centro- & 9.078 & 1,6 \\
Oeste & 369.231 & 65,4 \\
Nordeste & 41.653 & 7,4 \\
Norte & 61.259 & 10,8 \\
Sudeste & 83.751 & 14,8 \\
Sul & $\mathbf{5 6 4 . 9 7 2}$ & $\mathbf{1 0 0}$ \\
Brasil &
\end{tabular}

Fonte: IPEA, 2010, p. 242.

Ainda dentro do universo dos "pequenos produtores" agricultores familiares há os assentados dos projetos de Reforma Agrária. Os assentados são sujeitos sociais expropriados de seus territórios, que necessitam resgatar o sentido ou sentimento de pertencimento que lhes foi enfraquecido ao longo de suas histórias, marcadas pela exclusão social, política, econômica e também territorial.

Os Projetos de Assentamentos de Reforma Agrária (PA) podem ser definidos a partir da criação de novas unidades de produção agrícola, por meio de políticas governamentais, visando ao reordenamento do uso da terra ou à busca de novos padrões sociais na organização do processo de produção agrícola.

Com a implantação do PA, muitas vezes ocorre o enfraquecimento da organização social, e uma máxima bastante comum entre os assentados é "antes o pessoal era mais unido, mais organizado". Esse enfraquecimento é dado pela ilusão da posse sobre a terra, ou melhor, pela ilusão de autonomia do controle sobre o território. Isso por que o assentado é antes de tudo um endividado, uma vez que terá no máximo 23 anos para pagar seu lote de terra. Ou seja, antes do pagamento de, no mínimo, 10 anos regulares, não é possível obter o título legal da propriedade, o que os impossibilita, por exemplo, de obter empréstimos bancários para a produção.

adquirindo lenha de terceiros, produtores em área de águas públicas para exploração da aquicultura e atividades de extração, coleta ou apanha de produtos que são extraídos de matas naturais (IBGE, 2009b). 
Mas a presença de programas que impulsionam o crédito e a produção se fazem presentes na vida dos assentados através do Programa Nacional de Reforma Agrária, o que já indica uma melhora na qualidade de vida desses sujeitos, pois antes encontravam-se completamente marginalizados desses processos.

Uma pesquisa sobre a qualidade de vida, produção e renda nos assentamentos da Reforma Agrária (PQRA), desenvolvida pelo INCRA e o MDA (Ministério do Desenvolvimento Agrário) em 2010, visava captar informações sobre quem são, como vivem, o que e como produzem, e o que pensam as famílias assentadas de todo o País (Mapa 1). A pesquisa estima que a população beneficiária da Reforma Agrária (em 2010) ultrapasse 3,6 milhões de pessoas no Brasil.

Assentamentos Pesquisados: 1.164

Questionários Aplicados 16.153

População: 804.867 famílias

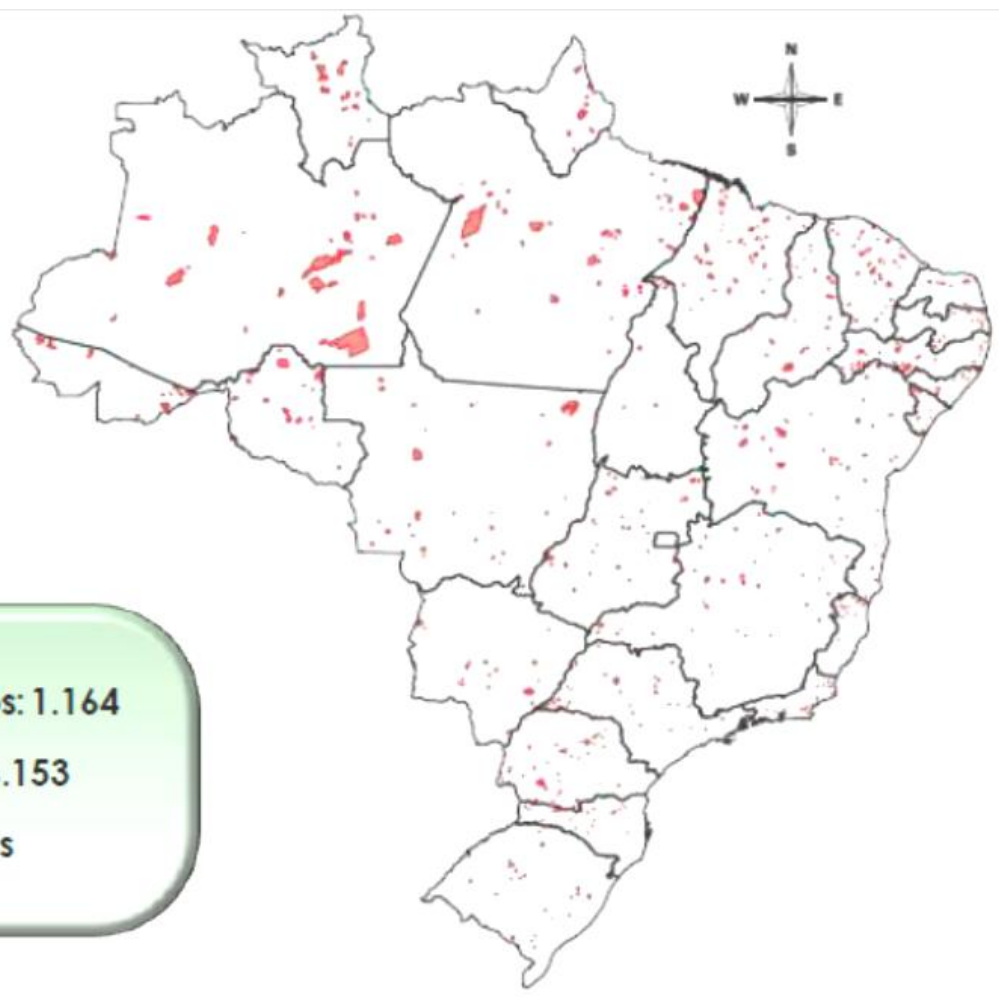

Mapa 1 - PA pesquisados na PQRA.

Fonte: BRASIL, 2010b, n.p.

Como resultados a pesquisa destaca: $70 \%$ das moradias possuem mais de cinco cômodos e $76 \%$ possuem algum tipo de tratamento de dejetos, $79 \%$ das famílias informam acesso suficiente à água, 76\% das famílias possuem energia elétrica em 
seus lotes, $57 \%$ das famílias informaram descontentamento com a condição das estradas e vias de acesso aos lotes, $84 \%$ é o nível de alfabetização dos assentados (o principal problema está no ensino médio e superior, com acesso inferior a 10\%), 56\% das famílias estão descontentes com o acesso a hospitais e postos de saúde, 52\% das famílias declararam acesso ao PRONAF (com inadimplência de 64\% delas), 62\% das famílias já receberam algum crédito de apoio inicial disponibilizado pelo INCRA, e por fim, dentre os mais de 200 produtos da Reforma Agrária, o leite, o milho e o feijão se destacam na formação da renda das famílias sendo que a produção agropecuária representa a maior fatia na composição dessa renda. Mas o mais importante que a pesquisa destaca refere-se à percepção de melhoria na condição após o assentamento (Gráfico 1).

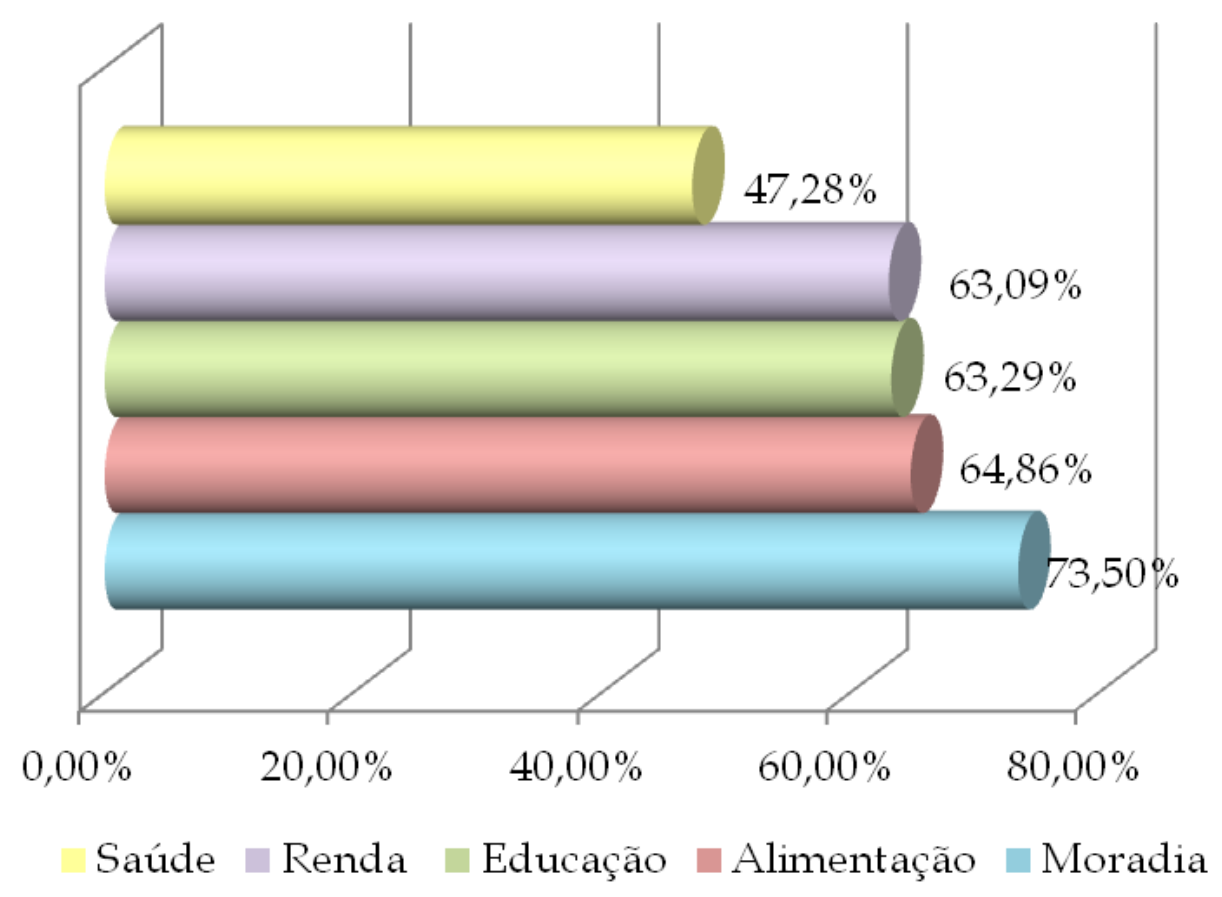

Gráfico 1 - Percepção de melhoria na condição após o assentamento (muito melhor ou melhor) ${ }^{19}$.

Fonte: BRASIL, 2010b, n.p.

19 Dados referentes à pergunta: "Comparando as condições de vida de sua família em relação à situação anterior ao assentamento, qual sua avaliação? (a) muito melhor; (b) melhor; (c) igual; (d) pior; (e) muito pior". (BRASIL, 2010b, n.p.). 
Boa parte da percepção positiva revelada pela pesquisa deve ser considerada com precauções. Isso por que o fato de a situação atual estar melhor que a anterior pode significar muito pouco, já que, muitas vezes, e por vários anos, a condição anterior ao assentamento era a de acampamento.

Apesar da percepção de melhora na vida dos assentados, e de representar a conversão de terras improdutivas em matriz de produção familiar, a política de Reforma Agrária posta em prática no Brasil se traduz numa política de criação de assentamentos cercados de problemas por todos os lados: há insuficiência de infraestrutura, moradia, crédito, assistência técnica, etc. Criados para atenuar os conflitos sociais no mundo rural, os PA não são inseridos num plano ou programa estratégico de desenvolvimento territorial. É por isso que os Projetos de Assentamentos de Reforma Agrária representam apenas uma conquista parcial, e se deparam com uma nova forma de exclusão social: a exclusão das políticas públicas, sociais e territoriais (BERGAMASCO; NORDER, 1996).

Para complementar a compreensão dos territórios rurais brasileiros, apoiamonos no entendimento de que as relações de poder são um dado fundamental para a compreensão dos territórios. Assim, a conceituação de Agricultura Familiar versus agronegócio revela, mais do que uma disputa conceitual, explicita processos políticos de resistência e luta, bem como de dominação (SAUER, 2008), ou seja, disputa por territórios.

No contexto de disputa, foi somado o processo de legitimação dos termos, o que estabeleceu o uso corrente deles. Isto expressa um antagonismo político e simbólico entre agronegócio e Agricultura Familiar. Assim, “esse processo histórico de disputa e apropriação transforma o conteúdo meramente descritivo em conceitos definidores de sujeitos e ações sociais" (SAUER, 2008).

[...] práticas distintas, frutos de lutas por classificação, criam a identidade e a identificação dos grupos nos processos de divisão do mundo social. [...]

Os mecanismos sociais e simbólicos (também identitários) de diferenciação (ou mesmo de oposição aberta) permitem, ou reforçam, as práticas e noções de unidade dos grupos sociais. Nessa perspectiva, os conceitos operativos (enunciados performativos) 
funcionam como definidores de identidades e identificação social de um pertencimento que os distancia de um "opositor". (SAUER, 2008, p. 32).

As "práticas distintas" são entendidas aqui como a luta pela terra (pelos agricultores familiares) ou manutenção da atual estrutura fundiária (pelo agronegócio). É necessário acrescentar mais um fator à discussão: o poder, pois "representar significa transformar os objetos, ou noções, em marcos referenciais ou em redes de significados carregadas de normas e valores" (SAUER, 2008). Assim, tanto para a Agricultura Familiar, quanto para o agronegócio, essa disputa é luta por poder, não só simbólico, como também político, econômico e territorial.

Vale recordar que desde a Lei de Terras de 1850, que institucionalizou juridicamente a posse da terra no Brasil, os interesses das antigas oligarquias rurais, hoje agronegócio, são transformados em decisões políticas que pautam nossas políticas públicas e também nossas leis. Algumas dessas leis apresentam objetivos claros, mas outros não são tão claros assim, como o caso da Lei de Terras, que impede o acesso à terra pelos imigrantes pobres e pelos escravos libertos (MEDEIROS, 2010).

Parece-nos claro que a discussão não deve girar em torno da questão agronegócio versus Agricultura Familiar, mas dentro da própria categoria Agricultura Familiar, visto que essa categoria engloba diferentes sujeitos sociais que apresentam relações sociais de produção e práticas sociais distintas. Mas há muito interesse em fragmentar e enfraquecer essa categoria social, para que esses diversos sujeitos sociais se mantenham marginalizados, e suas lutas e reivindicações se percam em discussões meramente teóricas. E claro, para que o agronegócio continue a exercer sua dominação política, econômica e territorial no mundo rural brasileiro.

Adotaremos agricultores familiares para nos referirmos aos sujeitos sociais relativos ao objeto da presente pesquisa, focando nos pequenos agricultores mais pobres, mesmo refletindo que, por vivermos em uma sociedade capitalista, em que o capital inevitavelmente diferencia grupos sociais, deveríamos estratificar a categoria social agricultores familiares, como fez a pesquisa INCRA/ FAO, para que as 
políticas públicas para esse segmento fossem melhor pensadas e implementadas. Mas será que é essa a intenção dos tomadores de decisões em nosso País?

Não serão incluídos na categoria Agricultura Familiar com que estamos trabalhando as comunidades tradicionais como índios e quilombolas. Isto por que esses sujeitos sociais apresentam outros tipos de relações sociais de produção e práticas sociais, e demandam estudos específicos, inclusive de categorias de análises que não utilizaremos na presente pesquisa. 


\section{Capítulo 02 - POLÍTICAS PÚBLICAS PARA O MUNDO RURAL: da política agrária e agrícola à cidadania rural.}

\subsection{Políticas Públicas para o mundo rural.}

Para alavancar o desenvolvimento de determinado território parece-nos claro o papel que o Estado tem através de suas políticas públicas, principalmente em se tratando de territórios historicamente menosprezados, como os rurais.

Podemos dizer que políticas públicas são a totalidade de ações, metas e planos que os governos (nacionais, estaduais ou municipais) traçam para alcançar o bemestar da sociedade e o interesse público, administrando seus recursos para equacionar os bens públicos em beneficio de sua população (GEHLEN, 2004).

Mas a sociedade, heterogênea que é, apresenta diversas demandas e expectativas quanto aos bens e interesses públicos. Assim, a política pública expressa relações de poder e de disputa, pois o interesse público se forma através da disputa de diversos grupos da sociedade e de diversos segmentos sociais.

A política pública prevê os princípios, metas e objetivos a serem alcançados, as competências institucionais e conselhos, os recursos e estabelece as ações e instrumentos. Para a aplicação da política, temos os planos e os programas, que também devem ter objetivos e instrumentos, mas em escalas mais específicas aos temas relacionados. Para o desenvolvimento dos planos e programas são propostos os projetos, mais práticos e pontuais, com ações mais dinâmicas e objetivas.

É certo que, numa sociedade democrática, poderíamos pensar que as ações que os governantes ou os tomadores de decisões selecionam como prioridades são aquelas que eles entendem serem as demandas ou expectativas da sociedade.

Porém, devemos lembrar que no jogo político de nossa sociedade capitalista contemporânea, que se diz democrática, nem sempre o que a política pública 
pretende é o que de fato se alcança. E a respeito de democracia, WEBER (1963) nos esclarece que:

Decerto devemos sempre lembrar que a expressão "democratização" pode ser enganosa. A própria demos, no sentido de uma massa inarticulada, jamais "governa" associações maiores; ao invés disso, é governada [...]. O aspecto mais decisivo no caso é o nivelamento dos governados em oposição ao grupo dominante e burocraticamente articulado [...]. (WEBER, 1963. In: GERTH; WRIGHT MILLS, 1982, p. 262 , grifos do autor).

As principais políticas públicas concernentes ao mundo rural brasileiro hoje são de responsabilidade de dois ministérios de agricultura, um cuidando de mecanismos tradicionais da política agrícola - MAPA (Ministério da Agricultura, Pecuária e Abastecimento) ${ }^{20}$ e o outro, da Reforma Agrária e da Agricultura Familiar - MDA 21 .

Os mecanismos tradicionais da política agrícola são entendidos aqui como os interesses do agronegócio ou da agricultura empresarial, como o próprio MAPA prefere denominar, e que foram se transformando em políticas implementadas pelos governos brasileiros, como já nos alertava MEDEIROS (2010), desde a Lei de Terras de 1850.

A Lei de Terras de 1850, que institucionalizou juridicamente a posse da terra, compreendia objetivos claros como a transição do trabalho escravo para o trabalho livre. Mas continha também outros objetivos, não tão claros, e alcançados, como o impedimento do acesso à terra pelos imigrantes pobres e pelos escravos libertos.

Em 1964, o Estatuto da Terra, apresentava como um de seus objetivos acabar com os latifúndios e minifúndios, mas com seu pacote de modernização e a busca da melhora de produção e de produtividade, as oligarquias rurais, ou seja, aqueles que já possuíam capital, foram os priorizados. A propaganda do governo na época,

20 O MAPA é responsável pela gestão das políticas públicas de estímulo à agropecuária, pelo fomento do agronegócio e pela regulação e normatização de serviços vinculados ao setor. (BRASIL, 2012b)

${ }^{21}$ A área de competência do Ministério do Desenvolvimento Agrário trata de: Reforma Agrária; promoção do desenvolvimento sustentável do segmento rural constituído pelos agricultores familiares; e identificação, reconhecimento, delimitação, demarcação e titulação das terras ocupadas pelos remanescentes das comunidades dos quilombos. (BRASIL, 2012c). 
"exportar é o que importa", demonstra mais uma vez que a agricultura de exportação, ou o agronegócio, estava sendo privilegiada.

Uma nova tentativa de modificar o domínio do agronegócio, veio em 1985 com o I Plano Nacional de Reforma Agrária (I PNRA), mas a pressão da bancada ruralista foi maior, e o I PNRA apresentou baixíssimos resultados. Também a Constituição de 1988 significou uma vitória para o agronegócio, pois derrubava o limite de propriedade e permitia que a propriedade produtiva deixasse de ser passível de desapropriação para fins de Reforma Agrária.

A partir daí, cada vez mais os interesses do agronegócio foram se transformando em políticas implementadas pelo governo. Exemplos disso não faltam: o Seguro Rural, o Fundo de Investimento do Agronegócio, o Certificado de Depósito Agropecuário e o Warrant Agropecuário, além da recente liberação da produção de soja transgênica pelo atual governo. Através do MAPA, o governo "não poupa esforços para estimular o agronegócio por meio da modernização da Política Agrícola" (MEDEIROS, 2010).

O que fica claro é que o agronegócio compõe “o grupo dominante e burocraticamente articulado" de que Weber nos falava. Assim começamos a nos questionar acerca das ações que os governantes ou os tomadores de decisões selecionam como prioridades, em especial no mundo rural, entendendo serem as demandas ou expectativas da sociedade, no caso, brasileira. E assim também nos perguntamos: quais demandas da sociedade determinada política se propõe a resolver?

Aqui voltamos ao antagonismo político e simbólico entre agronegócio e Agricultura Familiar de que falávamos no capítulo anterior, institucionalizado nesses dois ministérios de agricultura que existem atualmente no Brasil. Vale destacar que o orçamento do MAPA para o Plano Agrícola e Pecuário de 2012/13 foi de R\$ 115,25 bilhões para o financiamento da agricultura empresarial (BRASIL, 2012b), enquanto o MDA contou com $\mathrm{R} \$ 22,3$ bilhões para o Plano Safra da Agricultura Familiar no mesmo período (BRASIL, 2012c).

O MDA foi constituído no início da década de 2000 como um ministério setorial, integrando as áreas de Reforma Agrária e Agricultura Familiar em uma 
estrutura institucional que significou o reconhecimento político dos agricultores familiares pelo Estado. O MDA incorporou o INCRA 22, criou a Secretaria de Desenvolvimento Territorial (SDT), a Secretaria de Reordenamento Agrário (SRA), a Secretaria Extraordinária de Regularização Fundiária na Amazônia Legal (SERFAL), e a Secretaria da Agricultura Familiar (SAF) ${ }^{23}$. Esta última passou ser o "guardachuva institucional" das diversas linhas de ação do PRONAF e demais programas ligados à Agricultura Familiar brasileira (SCHNEIDER; MATTEI; CAZELLA; 2004).

O PRONAF tem se firmado como a principal política pública do Governo Federal para apoiar os agricultores familiares, e tem sido estruturante das ações públicas para o desenvolvimento rural do Brasil.

O contexto político, econômico e social em que se deu a criação do PRONAF foi o início da década de 1990, quando, a partir das primeiras medidas de abertura política e de redemocratização do Brasil, surgiram ou reorganizaram-se importantes movimentos de trabalhadores rurais reivindicando a implementação de políticas de apoio à Agricultura Familiar e à Reforma Agrária. Isto por que a crise dos anos 1980, particularmente no que se refere à disponibilidade de crédito e à queda da renda, afetou fortemente os agricultores familiares brasileiros, que se encontravam bastante debilitados e, ainda, ameaçados pela concorrência que a criação do MERCOSUL 24 abriria.

22 O INCRA é uma autarquia federal da administração pública brasileira responsável por implementar a política de Reforma Agrária, realizar o ordenamento fundiário nacional, manter o cadastro nacional de imóveis rurais e administrar as terras públicas da União. Esse assunto será melhor desenvolvido ao longo deste capítulo.

${ }^{23}$ A SDT contribui para o desenvolvimento harmônico de regiões onde predominam agricultores familiares e beneficiários da Reforma e do Reordenamento Agrários; a SRA atua na implementação de políticas públicas nacionais para o meio rural por meio de ações complementares à Reforma Agrária, como a garantia de acesso à terra pelo Crédito Fundiário; a SERFAL coordena, avalia e monitora as ações do Programa Terra Legal Amazônia, além de atuar conjuntamente com outros órgãos na formulação de políticas fundiárias para a região; a SAF tem por missão consolidar o conjunto da Agricultura Familiar de modo a promover o desenvolvimento local sustentável. (BRASIL, 2012c).

${ }^{24}$ O Mercado Comum do Sul (MERCOSUL) é um bloco econômico, que estabeleceu uma zona de livre comércio entre seus países membros. Criado pelo Tratado de Assunção (1991), conta com Brasil, Argentina, Uruguai, Paraguai e, mais recentemente (2012), com a Venezuela como países-membros. Equador, Chile, Colômbia, Peru, Bolívia participam como 
Somado à essa conjuntura, o Projeto de Cooperação Técnica INCRA/ FAO, produz um estudo em 1994 que definia com maior precisão conceitual a Agricultura Familiar brasileira, suas dimensões e heterogeneidade, demonstrando sua importância na geração de emprego e renda no Brasil. E, mais, estabelecia um conjunto de diretrizes que deveriam nortear a formulação de políticas públicas adequadas às especificidades dos diferentes tipos de agricultores familiares brasileiros (SCHNEIDER; MATTEI; CAZELLA; 2004).

Assim, pode-se afirmar que o PRONAF foi formulado como resposta do Estado às pressões dos movimentos sociais e sindicais rurais, realizadas desde o final da década de 80. O programa nasceu com a finalidade de prover crédito agrícola e apoio institucional aos pequenos produtores rurais ainda no governo Itamar Franco, e em 1996, através do Decreto Presidencial no 1.946, de 28 de julho de 1996, ocorre sua institucionalização com duas grandes linhas de ação: 1) Crédito de custeio e investimento e 2) PRONAF Infraestrutura e serviços municipais.

O PRONAF crédito de custeio e investimento, hoje chamado de PRONAF crédito rural, tem o objetivo de financiar projetos individuais ou coletivos de custeio da safra ou atividade agroindustrial, investimento em máquinas, equipamentos ou infraestrutura de produção e serviços agropecuários ou não agropecuários. $\mathrm{O}$ programa possui as mais baixas taxas de juros dos financiamentos rurais, e o financiamento se dá através dos sindicatos rurais ou Empresas de Assistência Técnica e Extensão Rural (Emater), via obtenção da Declaração de Aptidão ao PRONAF (DAP), que é emitida segundo a renda anual e as atividades exploradas, direcionando o agricultor para as linhas específicas de crédito. Para os beneficiários da Reforma Agrária e do Programa Nacional de Crédito Fundiário (PNCF) ${ }^{25}$, a DAP

membros associados, mas não possuem poder de voto. México participa apenas como membro observador.

25 O MDA/ SRA desenvolve o Programa Nacional de Crédito Fundiário (PNCF) que oferece condições para que os trabalhadores rurais sem terra ou com pouca terra possam comprar um imóvel rural por meio de um financiamento. O recurso ainda é usado na estruturação da infraestrutura necessária para a produção e assistência técnica e extensão rural. Possui três linhas de financiamento: 1) Combate à Pobreza Rural (para agricultores com renda familiar anual de até $\mathrm{R} \$ 9$ mil e patrimônio de até $\mathrm{R} \$ 15 \mathrm{mil}$ ); 2) Consolidação da Agricultura Familiar (para agricultores com renda familiar anual de até R\$ 15 mil e 
é emitida via INCRA ou via Unidade Técnica Estadual. As condições de acesso ao PRONAF, formas de pagamento e taxas de juros correspondentes a cada linha são definidas, anualmente, a cada Plano Safra da Agricultura Familiar, divulgado entre os meses de junho e julho.

O PRONAF Infraestrutura e serviços municipais foi uma linha especial do programa que vigorou até 2002 e voltava-se para os municípios rurais com perfil agropecuário, em especial aqueles com predominância da Agricultura Familiar, e seu intuito era sanar carências de infraestrutura mínima. Apoiava-se na concepção do desenvolvimento local e na organização da sociedade civil, através dos Conselhos Municipais de Desenvolvimento Rural Sustentável. Porém, a unidade municipal como lugar de planejamento e organização de esforços visando à promoção do desenvolvimento rural se mostrou pouco satisfatória e bastante propensa às ingerências político-partidárias de suas administrações municipais.

Em 2003/4, com a criação da Secretaria de Desenvolvimento Territorial, no âmbito do MDA, o PRONAF Infraestrutura e serviços foi incorporado ao Programa de Desenvolvimento Sustentável dos Territórios Rurais (PDSTR). O rompimento com o modelo anterior se dá pela ideia de desenvolvimento rural pautado na abordagem territorial, em que se estabelece a coordenação e a articulação de um grupo de municípios em torno de uma estratégia comum representando os interesses sociais e econômicos desse grupo de municípios.

Em 2008, o Governo Federal criou um novo programa: o Territórios da Cidadania, que englobaria as ações do PDSTR. Seu objetivo principal é promover o desenvolvimento econômico, através da superação da pobreza, geração de trabalho e renda, além de universalizar programas básicos de cidadania, por meio de uma estratégia de desenvolvimento territorial sustentável. Sua inovação está em não se limitar a enfrentar problemas específicos relativos à infraestrutura e serviços apenas,

patrimônio anual inferior a R\$ $30 \mathrm{mil}$ ); e 3) Nossa Primeira Terra (para agricultores com renda familiar anual de até $\mathrm{R} \$ 15$ mil e patrimônio anual inferior a $\mathrm{R} \$ 30 \mathrm{mil}$ ). Todo o procedimento para a contratação se dá inteiramente nos estados. (BRASIL, 2012c). 
mas combinar diferentes ações de diversos ministérios com o objetivo de reduzir as desigualdades sociais nos territórios rurais.

O governo federal tem criado ou incentivado programas já existentes de crédito, incentivos e assistência técnica para a Agricultura Familiar, como o PRONAF e o PROGER RURAL26 (ambos de 1995), e mais recentemente, via PRONAF Jovem²7, PNCF28, Programa de Aquisição de Alimentos (PAA) ${ }^{29}$, o Programa Nacional de Alimentação Escolar (PNAE) ${ }^{30}$, a criação do Selo da Agricultura Familiar ${ }^{31}$, e com o recente lançamento do Plano Nacional de Agroecologia e Produção Orgânica $\left(\right.$ Planapo $\left.^{32}\right)$. E ainda devemos lembrar os investimentos em políticas sociais, através

26 PROGER: Programa de Geração de Emprego e Renda do FAT (Fundo de Amparo ao Trabalhador). É uma linha de investimento destinada a financiar a implantação, ampliação e modernização da infraestrutura de produção e serviços nos estabelecimentos rurais, ou financiar despesas agrícolas e pecuárias, via linha de custeio. Destinada à agricultores familiares, pode ser contratada individual ou coletivamente. (BRASIL, 2012d).

27 Linha de crédito especial para incentivar a permanência de jovens no meio rural, filhos de agricultores entre 16 e 25 anos que tenham concluído ou estejam cursando o último ano de escolas técnicas.

28 Cf. nota de rodapé $n^{\circ} 25$.

29 Instituído pelo artigo 19 da Lei no 10.696/2003, o PAA utiliza mecanismos de comercialização que favorecem a aquisição direta de produtos de agricultores familiares ou de suas organizações. Parte dos alimentos é adquirida pelo governo diretamente dos agricultores familiares, assentados da Reforma Agrária, comunidades indígenas e demais povos e comunidades tradicionais, para a formação de estoques estratégicos e distribuição à população em maior vulnerabilidade social. Outra parte dos alimentos é adquirida pelas próprias organizações da Agricultura Familiar, para formação de estoques próprios. Para participar do Programa, o agricultor deve ser identificado como agricultor familiar, enquadrando-se no PRONAF. (BRASIL, 2012c).

30 O PNAE, também conhecido como Merenda Escolar, implantado em 1955, garante, por meio da transferência de recursos financeiros, a alimentação escolar dos alunos de toda a educação básica (educação infantil, ensino fundamental, ensino médio e educação de jovens e adultos) matriculados em escolas públicas e filantrópicas. O repasse é feito diretamente aos estados e municípios, com base no censo escolar realizado no ano anterior ao do atendimento. A Lei $n^{\circ} 11.947$, de 16/06/2009, define que 30\% do orçamento do programa devem ser investidos na compra direta de produtos da agricultura familiar. (BRASIL, 2012a).

31 O MDA, por meio da SAF, criou em 2009 o Programa Selo da Agricultura Familiar. Seu uso é de caráter voluntário e representa um sinal identificador de produtos, cujo objetivo é fortalecer a identidade social da agricultura familiar perante os consumidores, informar e divulgar a presença significativa da agricultura familiar nos produtos. A validade do Selo é de 5 anos, podendo ser renovado. É concedido a empresas e cooperativas e a agricultores familiares para identificar produtos como verduras, legumes, polpas de frutas e laticínios, entre outros. (BRASIL, 2012c).

32 O Planapo foi lançado em outubro/2013 com o objetivo de ampliar e efetivar ações para orientar o desenvolvimento rural sustentável, sendo o principal instrumento de 
de Programas como o Luz para Todos, que atingiu, sobretudo, as famílias rurais mais pobres, além de investimentos em infraestrutura, com destaque para a construção de cisternas no semiárido do Nordeste.

A respeito dos Programas de Habitação Rural, de que trataremos mais adiante (Capítulo 3), vale mencionar o Programa Nacional de Habitação Rural (PNHR) lançado em 2003, e mais recentemente, 2009, o Programa Minha Casa Minha Vida Rural.

Também sob responsabilidade do MDA está a Reforma Agrária, que pode ser definida como um conjunto de ações governamentais realizadas visando modificar a estrutura fundiária desigual de uma região ou de um país todo. Seu objetivo, enquanto reforma, é a transformação de uma estrutura agrária existente. É executada através de mudanças na distribuição da propriedade e/ou posse da terra.

Reforma agrária é o processo amplo, imediato e drástico de redistribuição de direitos sobre a propriedade privada da terra agrícola, promovida pelo Governo, com a ativa participação dos próprios camponeses e objetivando sua promoção humana, social, econômica e política. (GOMES DA SILVA, 1971, p. 37-38).

Além da política fundiária ou agrária, esta que trata do ordenamento do território, legislando sobre posse e/ou uso da propriedade privada da terra, bem como das terras da União, a política agrícola também é um dos pilares fundamentais da Reforma Agrária.

A política agrícola trata e regula a produção agrícola - o que, quanto e a qualidade do que se produz; o processamento, armazenamento, transporte e comercialização dos produtos e subprodutos; serviços e insumos agrícolas,

execução da Política Nacional de Agroecologia e Produção Orgânica. O Planapo visa articular e implementar programas e ações indutoras da transição agroecológica, da produção orgânica e de base agroecológica, como contribuição para o desenvolvimento sustentável, possibilitando à população a melhoria de qualidade de vida por meio da oferta e consumo de alimentos saudáveis e do uso sustentável dos recursos naturais. Seu público alvo são agricultores, assentados da Reforma Agrária, povos e comunidades tradicionais, incluindo a juventude rural, e suas organizações econômicas, que queiram fortalecer ou modificar suas práticas produtivas para sistemas agroecológicos ou orgânicos de produção. (BRASIL, 2012c). 
pecuários, pesqueiros e florestais; incentivo à pesquisa e à tecnologia; instrumentos creditícios, fiscais, de seguros e de regulação de preços; infraestrutura, como luz, água, moradia; e ainda assistência técnica e extensão rural.

Importante destacar que nos anos 90, a Lei $n^{\circ} 8.213$, de 24 de julho de 1991, que dispõe sobre os Planos de Benefícios da Previdência Social, passa a tratar como "segurados especiais" os trabalhadores rurais, seja "proprietário, usufrutuário, possuidor, assentado, parceiro ou meeiro outorgados, comodatário ou arrendatário rurais", "seringueiro ou extrativista vegetal", "pescador artesanal", bem como seus “cônjuges ou companheiros, além do filho maior de dezesseis anos de idade". Essa lei ampliou a cobertura da Previdência Social para o mundo rural, garantindo através das pensões e aposentadorias uma renda mínima para suporte da agricultura familiar, principalmente nas regiões mais pobres do País.

\subsection{Rápida contextualização da Reforma Agrária no Brasil}

No Brasil, a história da Reforma Agrária surge como uma luta com o nascimento dos movimentos sociais do campo, particularmente das Ligas Camponesas, formadas a partir dos anos 1940, as quais denunciavam o estado de tensão e injustiças a que estavam submetidos os sujeitos sociais rurais.

O movimento das Ligas se iniciou no Engenho Galiléia, no Estado de Pernambuco, em 1955, contra a alta dos preços dos arrendamentos. Até esse episódio, as Ligas ainda não tinham ganhado força ou repercussão social e política, mas a partir daí tomam corpo por todo o País e se tornam o primeiro movimento social de defesa dos direitos do homem rural e da Reforma Agrária.

Depois do fim da Segunda Guerra Mundial, o Brasil redemocratizado intensifica ainda mais seu processo de industrialização e urbanização, e a questão agrária começa a ser discutida como um obstáculo ao desenvolvimento do País. As chamadas reformas de base (agrária, urbana, bancária e universitária) eram 
consideradas essenciais para o desenvolvimento econômico e social do País pelos governos que se instauraram até 1964.

As primeiras propostas de lei sobre a Reforma Agrária no Brasil surgiram após a Constituição Federal de 1946 e baseavam-se principalmente nos princípios de desapropriação por interesse social e justa distribuição da propriedade. Porém, até o início dos anos 60, nenhum projeto de lei que articulasse esses princípios e que pudesse se constituir numa efetiva proposta de Reforma Agrária tornou-se lei.

Em 1962, no governo de João Goulart (1961 - 1964), foi criada a Superintendência de Política Agrária (SUPRA), o primeiro órgão federal de execução de programas de colonização e Reforma Agrária no País. Em 1963, foi aprovado o Estatuto do Trabalhador Rural, regulando as relações de trabalho no mundo rural e permitindo a implantação do sindicalismo rural. Em 1964, João Goulart assina um decreto prevendo a desapropriação, para fins de Reforma Agrária, das terras localizadas numa faixa de dez quilômetros ao longo das rodovias, ferrovias e açudes construídos pela União.

Não houve tempo para se executar a Reforma Agrária que João Goulart propunha, já que no mesmo ano o golpe militar pôs fim ao seu governo. É instaurada no País a ditadura militar, que pratica a perseguição e a "matança" das lideranças do movimento das Ligas Camponesas, o que tornou sua desarticulação inevitável. Porém, por mais contraditório que possa parecer, foi nesse mesmo governo militar que a primeira lei brasileira de Reforma Agrária foi promulgada.

Logo após assumir o poder em 1964, os militares incluíram a Reforma Agrária entre suas prioridades, com a garantia aos congressistas latifundiários de que a lei não sairia do papel. Apesar de o movimento social rural ter sido fortemente reprimido, havia um quadro de pressão social interna e, sobretudo externa ${ }^{33}$, que obrigou os militares a incluírem a Reforma Agrária em suas prioridades.

33 As pressões internas deviam-se ao crescimento dos movimentos sociais de luta pela terra, e as externas por conta da "onda socialista" que crescia mundo afora. 
No dia 30 de novembro de 1964, é sancionada a Lei $\mathrm{n}^{\circ} 4.504$, que trata do Estatuto da Terra. Seus princípios são a execução da Reforma Agrária e a promoção da política agrícola, e seu conceito fundante é a função social da propriedade de terra, definida em seu artigo segundo:

Art. $2^{\circ}$ É assegurada a todos a oportunidade de acesso à propriedade da terra, condicionada pela sua função social, na forma prevista nesta Lei.

$\S 1^{\circ}$ A propriedade da terra desempenha integralmente a sua função social quando, simultaneamente:

a) favorece o bem-estar dos proprietários e dos trabalhadores que nela labutam, assim como de suas famílias;

b) mantém níveis satisfatórios de produtividade;

c) assegura a conservação dos recursos naturais;

d) observa as disposições legais que regulam as justas relações de trabalho entre os que a possuem e a cultivem. (BRASIL, Lei $\mathrm{n}^{\circ} 4.504$, de 30 de novembro de 1964. Estatuto da Terra).

Em seu artigo $4^{\circ}$, o Estatuto define a propriedade familiar, mais um conceito importante para a compreensão da história da Reforma Agrária no Brasil:

Art. $4^{\circ}$ Para os efeitos desta Lei, definem-se:

I - Imóvel Rural [...];

II - Propriedade Familiar, o imóvel rural que, direta e pessoalmente explorado pelo agricultor e sua família, lhes absorva toda a força de trabalho, garantindo-lhes a subsistência e o progresso social e econômico, com área máxima fixada para cada região e tipo de exploração, e eventualmente trabalho com a ajuda de terceiros; [...]. (BRASIL, Lei n ${ }^{\circ} 4.504$, de 30 de novembro de 1964. Estatuto da Terra).

O Estatuto criou institutos ${ }^{34}$ encarregados do cadastro de todas as propriedades de terra do País, dos processos de colonização de terras públicas e de desapropriação de terras; criou uma classificação geral para as propriedades ${ }^{35}$; estipulou critérios para o pagamento das áreas desapropriadas ${ }^{36}$; instituiu a obrigatoriedade do

${ }^{34}$ Em substituição à SUPRA, foram criados o IBRA (Instituto Brasileiro de Reforma Agrária) responsável pela reforma da estrutura fundiária e o INDA (Instituto Nacional de Desenvolvimento Agrário), responsável pelo processo de colonização.

35 Baseada em tamanho, utilização e capacidade de produção.

36 Os critérios para o pagamento das áreas desapropriadas estavam baseados na Constituição de 1946. Art. 141 § 16 - É garantido o direito de propriedade, salvo o caso de desapropriação por necessidade ou utilidade pública, ou por interesse social, mediante prévia e justa indenização em dinheiro. Em caso de perigo iminente, como guerra ou 
pagamento do Imposto Territorial Rural (ITR) ${ }^{37}$; previa o zoneamento das áreas sujeitas à Reforma Agrária; previa a elaboração dos Planos Regionais e do Plano Nacional de Reforma Agrária; e ainda estabelecia a gradual extinção do minifúndio e do latifúndio.

O governo militar priorizou a execução da política agrícola, promovendo a modernização do latifúndio, por meio de crédito rural fortemente subsidiado e abundante, o que propiciou o desenvolvimento capitalista da agricultura nos grandes latifúndios - o agronegócio.

O resultado da política agrária do regime militar acabou reforçando o poder do latifúndio tradicional, das grandes empresas nacionais e multinacionais. Projetos agrícolas, agroindustriais, agropecuários, financiados pelo Governo, transformaramse em latifúndios enormes que produziam principalmente soja para exportação, e apoderavam-se de terras de posseiros e índios.

O projeto de Reforma Agrária foi substituído, a partir dos anos 70, especialmente na Amazônia, por programas de colonização, que o governo chamava de "programas especiais de desenvolvimento regional". A ideia era fazer a Reforma Agrária necessária para o Nordeste nas terras da Amazônia, ou “como preferia dizer o General Médici, vamos levar os homens sem terra do Nordeste para as terras sem homens da Amazônia" (OLIVEIRA, 2007).

Com o fim do governo militar, começaram a surgir greves e inquietações no mundo rural. A Igreja Católica e outras instituições religiosas passaram a apoiar os trabalhadores rurais. Em 1985, é eleito Tancredo Neves, que não chega a assumir a presidência por causa de sua morte, mas que antes prometera a Reforma Agrária aos trabalhadores rurais e ao Papa.

comoção intestina, as autoridades competentes poderão usar da propriedade particular, se assim o exigir o bem público, ficando, todavia, assegurado o direito a indenização ulterior. (BRASIL, 1946).

37 O ITR teria seus recursos destinados ao programa de Reforma Agrária. Vale lembrar que seu valor é autodeclaratório. 
Em março de 1985, José Sarney assume a "Nova República" e também a promessa do presidente morto feita ao Papa de realizar a Reforma Agrária. Em outubro do mesmo ano é aprovado o Primeiro Plano Nacional de Reforma Agrária (I PNRA), previsto no Estatuto da Terra de 1964.

\begin{abstract}
A primeira previsão para assentamento entre 1985 e 1989 apresentava em termos totais para o Brasil 1.400 .000 famílias em uma área de 43.090.000 hectares. [...] Em 1985 com a implantação do plano, passou a ocorrer forte luta entre a UDR (União Democrática Ruralista) ${ }^{38}$, o governo Sarney e os camponeses sem-terra, posseiros, etc. O objetivo da UDR foi a inviabilização da implantação do I PNRA. [...] Os números referentes ao primeiro ano do Plano (85/86) traziam já, o fracasso da reforma agrária da "Nova República" de José Sarney. Havia sido atingido apenas $5 \%$ das metas das famílias assentadas e da área desapropriada. Depois, no segundo ano (86/87) o ritmo continuou lento. (OLIVEIRA, 2007, p. 126).
\end{abstract}

Com os baixos resultados da Reforma Agrária promovida pelo governo Sarney, a década de 80 registrou um grande avanço nos movimentos sociais organizados de luta pela terra.

No final da década de 80, a promulgação da Constituição veio dar novo fôlego aos que lutavam por terra e por melhores condições de vida no mundo rural. A Constituição, em seu artigo $5^{\circ}$, inciso XXVII, estabelece como “direito e garantia fundamentais" individuais e coletivos que a propriedade atenderá a sua função social. Também no artigo $170^{\circ}$, a propósito dos Princípios Gerais da Atividade Econômica, a função social da propriedade é assegurada. No artigo 186 (Da Política Agrícola e Fundiária e da Reforma Agrária), a Carta Magna define o que é a função social da propriedade, com o mesmo teor do texto apresentado no Estatuto da Terra. Já em seu artigo 185, define os imóveis suscetíveis de “desapropriação para fins de reforma agrária" (BRASIL, 1988a).

Mas o poder da "bancada ruralista" não permitiu grandes avanços na Constituinte, e a Constituição de 1988 significou uma derrota para a Reforma

38 “A UDR foi fundada em agosto de 1985, em Goiânia, durante um leilão de gado para arrecadar dinheiro entre os latifundiários, para lutarem contra a reforma agrária do I PNRA e contra o avanço do movimento dos camponeses sem-terra." (OLIVEIRA, 2007, p. 127). 
Agrária, e, principalmente, para o I PNRA, pois derrubava o limite de propriedade (mesmo que alto, o Estatuto da Terra ainda estipulava limites) e permitia que a propriedade produtiva deixasse de ser passível de desapropriação para fins de Reforma Agrária.

Com a reforma da Constituição brasileira em 1988 é referendado o poder dos ruralistas, em maioria agroexportadores, e lançado por terra qualquer intenção ou objetivo de reforma agrária. A nova Constituição Federal no seu Capítulo III - Da Política Agrícola e Fundiária e da Reforma Agrária redefini a função social da terra, compatibiliza política agrícola com reforma agrária e estabelece tratamento especial à propriedade produtiva. (MEDEIROS, 2010, p. 256).

Em relação ao "tratamento especial à propriedade produtiva", cabe um duplo entendimento, ambos equivocados: se produtiva for interpretado como fértil, significa que a destinação para a Reforma Agrária somente pode ocorrer com terras inférteis, sem possibilidade de exploração agrícola. Outro entendimento é que, mesmo que descumpra sua função social (por exemplo, explorando trabalho escravo ou devastando áreas de preservação permanente), uma vez que seja produtiva (ou explorada economicamente), a terra não poderá ser desapropriada. É o predomínio do critério econômico em detrimento do social e ambiental.

Durante os anos 90, no campo normativo, a Lei dos Planos de Benefícios da Previdência Social, aprovada em 1991, ampliou a cobertura da Previdência Social para o mundo rural, mas em termos de Reforma Agrária, nenhum dos governos elaborou um novo plano, e o cumprimento tanto das metas de desapropriação, quanto de assentamento de fato de novas famílias, ainda do I PNRA, foi sempre muito baixo. O movimento social de luta pela terra respondeu a essa morosidade com ocupações de terra, e o governo, por sua vez, com violência.

Enquanto a política do MST [Movimento dos Trabalhadores sem Terra] era de colocar a nu a terra improdutiva e a grilagem de terra pelos latifundiários, a resposta foi a violência policial ou a criminalização das lideranças. Foram os casos do Pontal do Paranapanema no estado de São Paulo, do massacre de Corumbiara em Rondônia e Eldorado do Carajás no Pará. (OLIVEIRA, 2007, p. 143). 
Em 2003, a eleição de Luiz Inácio Lula da Silva para a Presidência da República trouxe novas esperanças aos movimentos de luta pela terra e pela Reforma Agrária de que finalmente a estrutura agrária brasileira seria transformada através da realização de uma verdadeira Reforma Agrária. Apesar de não apresentar um plano de Reforma Agrária, Lula havia prometido aos movimentos sociais que faria a tão esperada Reforma.

Depois de uma grande marcha de Goiânia a Brasília mobilizada pelo MST e outros movimentos sociais de luta pela terra, em 2003, um projeto para o Segundo Plano Nacional de Reforma Agrária (II PNRA) é encomendado a uma equipe técnica coordenada pelo professor Plínio de Arruda Sampaio. Os estudos dessa equipe concluíram que havia terra disponível no País, tanto improdutiva como devoluta ${ }^{39}$, que existia público para a Reforma Agrária e que seu custo seria perfeitamente viável. Foi estabelecida a meta de assentamento de um milhão de famílias a serem beneficiadas no período 2004 a 2007.

Porém, o plano adotado pelo governo Lula não foi o produzido pela equipe do professor Plínio, e suas metas eram bem menos pretensiosas:

METAS II PNRA - 2003/2006

META 1 - 400.000 novas famílias assentadas;

META 2 - 500.000 famílias com posses regularizadas;

META 3 - 150.000 famílias beneficiadas pelo Crédito Fundiário;

META 4 - Recuperar a capacidade produtiva e a viabilidade econômica dos atuais assentamentos;

META 5 - Criar 2.075.000 novos postos permanentes de trabalho no setor reformado;

META 6 - Implementar cadastramento georreferenciado do território nacional e regularização de 2,2 milhões de imóveis rurais;

META 7 - Reconhecer, demarcar e titular áreas de comunidades quilombolas;

META 8 - Garantir o reassentamento dos ocupantes não índios de áreas indígenas;

39 Terras devolutas são terras públicas (pertencentes ao Estado) que nunca pertenceram a um particular, mesmo estando ocupadas, e que não estão aplicadas a algum uso público federal, estadual ou municipal comum (bens de uso comum do povo, como: praças, jardins, praias, etc.) ou especial (local onde se realiza uma atividade pública ou onde se encontra um serviço público, como: teatros, universidades, etc.). O termo "devolutas" relaciona-se com a devolução destas terras ao domínio público. 
META 9 - Promover a igualdade de gênero na Reforma Agrária;

META 10 - Garantir assistência técnica e extensão rural, capacitação, crédito e políticas de comercialização a todas as famílias das áreas reformadas;

META 11 - Universalizar o direito à educação, à cultura e à seguridade social nas áreas reformadas.

(BRASIL. II Plano Nacional de Reforma Agrária. Paz, Produção e Qualidade de Vida no Meio Rural. MDA/INCRA, 2003, p. 38).

Infelizmente, as metas do II PNRA não vêm sendo cumpridas. As restrições orçamentárias, a insuficiência de quadro técnico, principalmente no INCRA, além da legislação desatualizada, contribuem para a não execução da Reforma Agrária, além, é claro, da falta de vontade política de se implementar de fato tal projeto.

Em relação a essa mesma vontade política, o governo manipula os dados do INCRA ${ }^{40}$, inflando-os, somando o que é projeto de colonização em terras públicas, regularização fundiária (para o caso de posseiros), reconhecimento/ demarcação de comunidades tradicionais (quilombolas, índios), reassentamento de atingidos por barragens, reconhecimento de assentamentos antigos (para acesso a créditos) e Reforma Agrária de fato (desapropriação).

Nos documentos originais aprovados pelo governo Lula em 2003, estava também, a distribuição das metas pelos diferentes anos de governo. Isto quer dizer que o MDA/INCRA sempre soube muito bem a distinção entre a Meta 1 dos assentamentos novos e as demais metas, tais como a da regularização fundiária (Meta 2), a reordenação fundiária, reassentamento de atingidos por barragens e $\mathrm{o}$ reconhecimento de assentamentos antigos para recuperar suas capacidades produtivas. Obviamente, sempre foram metas distintas, porque não são as mesmas coisas, pois as formas de obtenção das terras são diferentes. [...] Isto quer dizer que desde 2003, o MDA/INCRA vem faltando com a verdade para com a sociedade brasileira, e mais ainda, para com os movimentos sociais e sindicais que lutam pela reforma agrária. Quando se divulga um dado total que é produto da soma de metas desiguais, tenta-se passar para todos que estes dados referem-se ao cumprimento da Meta 1, os assentamentos novos reivindicados pelos movimentos sociais. (OLIVEIRA, 2007, p. 163- 164).

40 Importante enfatizar que esta prática de manipulação dos dados do INCRA não é exclusiva do Governo Lula. 
Apesar de toda a manipulação dos dados do INCRA, o governo Lula tratou a Reforma Agrária ampliando os investimentos nos Projetos de Assentamentos, criando e incrementando programas já existentes de crédito, incentivos e assistência técnica para a os assentados dos Programas de Reforma Agrária, tais como o PRONAF, e Programa de Assessoria Técnica, Social e Ambiental à Reforma Agrária (ATES) ${ }^{41}$. Paralelamente, o governo Lula também tratou de expandir ao mundo rural as políticas sociais, como o Luz para Todos, e a construção de cisternas.

Mas, desde os anos finais do governo Lula, as desapropriações para fins de Reforma Agrária praticamente desapareceram da agenda governamental, e a gestão do governo Dilma Rousseff (2011 até a atualidade) vem registrando os piores números desde 1995 em assentamentos novos (Gráfico 2), segundo dados divulgados pelo INCRA no início de 2013.

Uma leitura para a morosidade do governo Dilma em executar a Reforma Agrária é dada por analistas alinhados aos movimentos sociais de luta pela terra, que veem o foco desse governo na economia, emprego e desenvolvimento, sendo o mundo rural apenas uma base exportadora para equilibrar a balança comercial. $\mathrm{O}$ governo Dilma fez a "opção estratégica" pelo modelo do agronegócio, a partir de grandes propriedades, monocultura e provisão de commodities. Assim, esse governo não acredita na Reforma Agrária como um mecanismo efetivo de desenvolvimento nacional e promoção da igualdade, no máximo vincula o Programa de Reforma Agrária ao Programa de erradicação da miséria.

${ }^{41}$ O Programa de Assessoria Técnica, Social e Ambiental à Reforma Agrária - ATES, foi criado em 2003 com o objetivo de assessorar técnica, social e ambientalmente as famílias assentadas nos projetos de assentamento da Reforma Agrária, criados ou reconhecidos pelo INCRA. É executado em parceria com instituições públicas, privadas, entidades de representação dos trabalhadores rurais e organizações não governamentais ligadas à Reforma Agrária. 


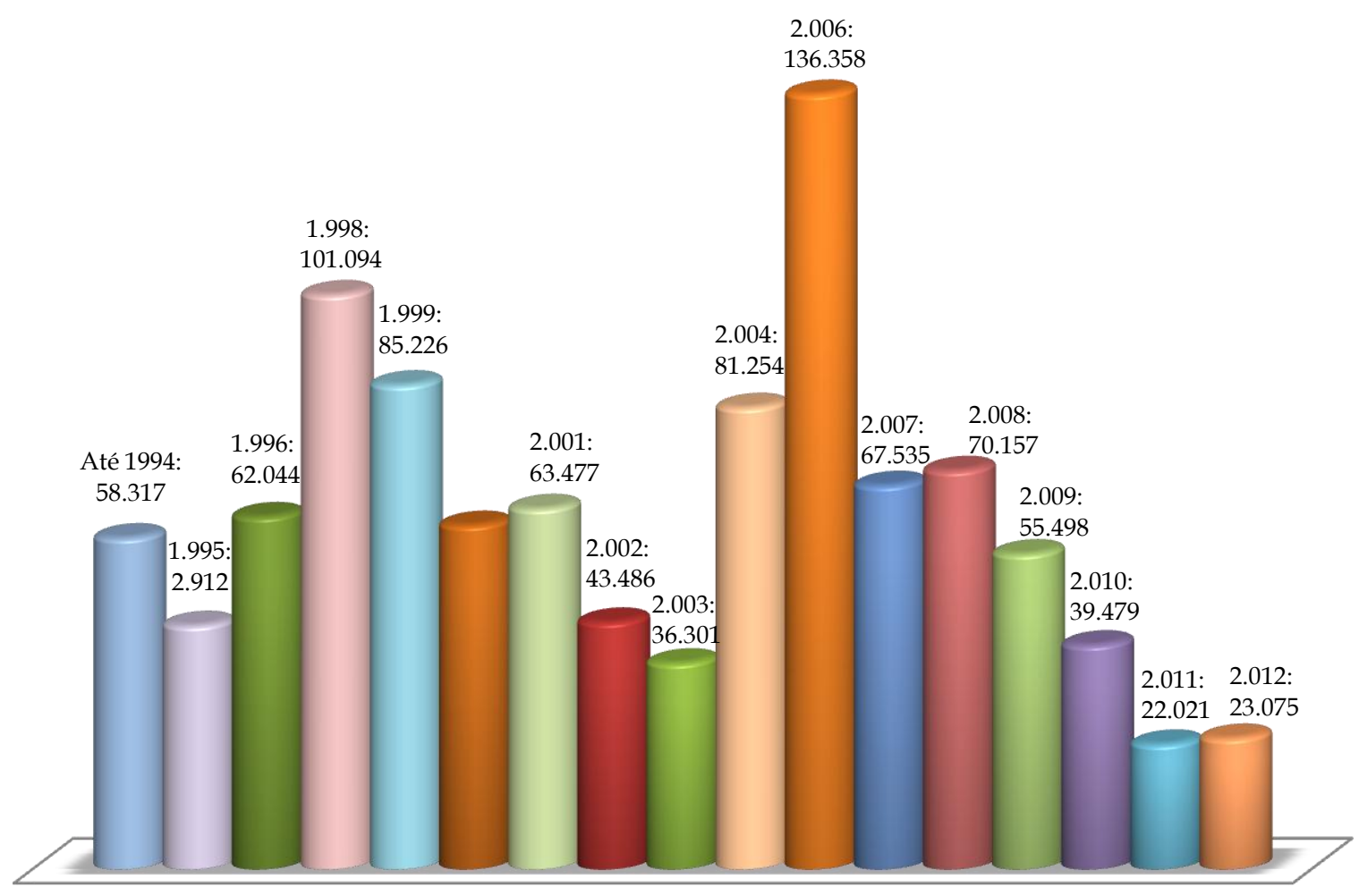

Gráfico 2 - Execução anual de famílias assentadas - INCRA - Brasil, até 2012.

\section{Fonte: INCRA. Famílias assentadas - Adaptado para o presente trabalho.}

A Reforma Agrária, nessa perspectiva, é dada como obsoleta, pois nos últimos quarenta anos o País passou por um processo de modernização da agricultura, o que tornou a tecnologia o grande fator de redução da desigualdade. Portanto, o acesso à tecnologia é a questão chave do problema agrário brasileiro, e não a democratização do acesso à terra. Assim, a solução do problema agrário brasileiro se assenta na modernização tecnológica, sem necessariamente passar pela democratização do acesso às terras.

O Brasil é o país de maior concentração da propriedade fundiária em todo o mundo. São 360 milhões de hectares, sob a forma de propriedade privada, sendo que apenas 60 milhões são utilizados pela agricultura. O que resta é pecuária extensiva, área inutilizada, ou mesmo área para especulação. Ou seja, os latifundiários e as grandes empresas querem terra apenas como reserva de valor.

Mesmo com esta conjuntura, o modelo atual da agricultura tem beneficiado as políticas estruturantes do agronegócio. Essa escolha causa impactos diretos em qualquer processo de democratização do acesso à terra. A realidade, hoje, mostra que a política de criação de assentamentos está parada, mesmo existindo 69.233 grandes propriedades improdutivas no país, que controlam 228 milhões de 
hectares de terra (IBGE/Censo de 2010), que deveriam ser destinadas à Reforma Agrária pela Constituição. (MST, 2013, n.p.).

O governo Dilma se defende justificando que muitos Projetos de Assentamentos se transformaram "quase que em favelas rurais", com abandono ou transferência ilegal de lotes, descumprimento de cláusulas contratuais e grande endividamento e inadimplência das famílias assentadas. Por isso mesmo, o governo essa "repensando" a questão da Reforma Agrária e o tipo de assentamento que o governo promove e promoverá. O foco deste governo, tal qual do governo Lula, é o fortalecimento dos PA já implantados através de políticas públicas voltadas à qualidade de vida dos assentados e assistência técnica para a produção. Bom exemplo é o recente lançamento do Programa Terra Forte (fevereiro de 2013), que tem por objetivo promover e apoiar a agroindustrialização em PA.

Porém, alguns intelectuais defendem que a política de créditos governamental pode ser a responsável pela realidade de abandono dos Projetos de Assentamentos de Reforma Agrária brasileiros. Isto porque os assentados, por sua origem de vulnerabilidade social, não possuem capacidade para pagar os créditos, em sua maioria com a finalidade de suprir necessidades básicas para sua reprodução social.

Parte da paralisia da Reforma Agrária também pode ser atribuída ao seu órgão promotor, o INCRA, pois disputas internas, greves, cortes no orçamento e burocratização o tornaram inoperante. Vale mencionar o caso da nomeação tardia do superintendente do INCRA, três meses após o início da gestão Dilma, bem como a nomeação dos superintendentes regionais, que, em alguns casos, levou mais de sete meses.

Apesar de toda a paralisia da Reforma Agrária brasileira, a demanda por terras permanece na sociedade brasileira, e segundo o Instituto de Pesquisa Econômica Aplicada, IPEA, (2010), passava de 4 milhões de famílias em 2010 (Tabela 4), podendo alcançar 5,5 milhões de famílias em 2022. 
Tabela 4 - Demanda por terra no Brasil.

\begin{tabular}{lcccc}
\hline \multicolumn{1}{c}{ Categoria } & $\begin{array}{c}\text { Total de } \\
\text { imóveis }\end{array}$ & $\begin{array}{c}\text { Área própria } \\
\text { (ha) }\end{array}$ & $\begin{array}{c}\text { Área mínima } \\
\text { necessária (ha) }\end{array}$ & Déficit \\
\hline Minifundiários & 3.366 .897 & $48.334 .053,31$ & $124.458 .074,00$ & $-76.124 .020,69$ \\
Acampados & 238.223 & 0,00 & $10.832 .082,24$ & $-10.832 .082,24$ \\
Precários & 564.972 & 0,00 & $26.638 .606,00$ & $-26.638 .606,00$ \\
$\quad$ Total & $\mathbf{4 . 1 7 0 . 0 9 2}$ & $\mathbf{4 8 . 3 3 4 . 0 5 3 , 3 1}$ & $\mathbf{1 6 1 . 9 2 8 . 7 6 2 , 2 4}$ & $\mathbf{- 1 1 3 . 5 9 4 . 7 0 8 , 9 3}$ \\
\hline
\end{tabular}

Fonte: IPEA, 2010, p. 244.

Como grupo prioritário da demanda por terra, podemos destacar as famílias acampadas, que em 2009 somavam cerca de 238 mil cadastradas pelo INCRA. Os agricultores "precários" também se somam à demanda. E por fim, os minifundiários, o que nos leva a:

Mas acabar com a demanda por terras não é o suficiente. A política de distribuição de terras deve considerar a formação de um estoque fundiário para evitar novas fragmentações das propriedades familiares, o que pode reconduzir à minifundização do mundo rural. Afinal, uma "estrutura fundiária mais equitativa é aquela que permite a reprodução de novos estabelecimentos familiares em condições de sustentar e desenvolver as famílias de agricultores" (IPEA, 2010, p. 244).

\subsection{INCRA}

Até 1970, os órgãos responsáveis por promover a Reforma Agrária, o IBRA (Instituto Brasileiro de Reforma Agrária - responsável pela reforma da estrutura fundiária) e o INDA (Instituto Nacional de Desenvolvimento Agrário - responsável pelo processo de colonização), foram marcados por intensos processos de corrupção. Em 1970, a partir da fusão desses órgãos, o INCRA é criado ${ }^{42}$. O INCRA é uma

42 O INCRA foi criado através do Decreto-Lei no 1.110 de 09/07/1970. Em 1985 foi criado o MIRAD (Ministério da Reforma e do Desenvolvimento Agrário) absorvendo algumas responsabilidades antes do INCRA. O INCRA foi extinto em 
autarquia federal da administração pública brasileira, hoje ligada ao MDA, responsável por implementar a política de Reforma Agrária, realizar o ordenamento fundiário nacional, manter o cadastro nacional de imóveis rurais e administrar as terras públicas da União.

O INCRA está implementado em todo o território nacional por meio de suas 30 Superintendências Regionais (SR $)^{43}$. Cada uma das superintendências é um órgão descentralizado, responsável pelas ações do INCRA em seu estado ou região. Cabe a cada SR coordenar e executar atividades relacionadas a planejamento, programação, orçamento e administração. Também devem garantir a manutenção, fidedignidade, atualização e disseminação de dados do cadastro de imóveis rurais e sistemas de informações do INCRA.

Cada SR conta com um Superintendente Regional, um Superintendente Regional Substituto, que compõe o Gabinete, e uma Procuradoria Federal Especializada, para assuntos jurídicos. As demais divisões são todas subordinadas ao Gabinete. São elas:

A - administração: administração em geral, orçamento, finanças, contabilidade e recursos humanos;

F - ordenamento da estrutura fundiária: cadastro rural (cadastro nacional de imóveis rurais, de proprietários e detentores de imóveis rurais, de terras públicas, de arrendatários e parceiros), cartografia (georreferenciamento de imóveis), regularização fundiária (discriminação, arrecadação e destinação de terras devolutas federais) e de territórios quilombolas (identificação, reconhecimento, delimitação, demarcação e titulação);

1987. Em 1989 o MIRAD é extinto e o Congresso Nacional recria o INCRA, vinculando-o ao Ministério da Agricultura. Em 1996 é criado o Ministério Extraordinário de Política Fundiária, ao qual o INCRA se incorpora. Em 14 de janeiro de 2000, o Decreto no 3.338 criou o Ministério do Desenvolvimento Agrário (MDA), órgão ao qual o INCRA está vinculado hoje. (INCRA, [2010]).

${ }^{43}$ Esse número se deve ao fato de existirem duas unidades federativas com mais de uma SR, são elas: Pará (SR Belém, SR Marabá e SR Santarém) e Pernambuco (SR Médio São Francisco e SR Recife). Estas, somadas às outras 25 unidades federativas (24 estados e o DF), resultam nas 30 SR. 
T - obtenção de terras: obtenção de terras (por meio de compra, desapropriação ou incorporação de terras públicas federais ao patrimônio do INCRA), implantação de assentamentos (criação ou reconhecimento), meio ambiente e recursos naturais;

$D$ - desenvolvimento: desenvolvimento de assentamentos através do Programa de Assessoria Técnica, Social e Ambiental à Reforma Agrária - ATES, concessão e acompanhamento de créditos, infraestrutura (estradas, água, saneamento), educação e cidadania.

Merece destaque o Programa ATES, que foi criado em 2003 com o objetivo de assessorar técnica, social e ambientalmente as famílias assentadas nos Projetos de Assentamento da Reforma Agrária, criados ou reconhecidos ${ }^{44}$ pelo INCRA.

A ATES é executada em parceria com instituições públicas, privadas, entidades de representação dos trabalhadores rurais e organizações não governamentais ligadas à Reforma Agrária. O programa atua com equipes técnicas constituídas por profissionais das ciências agrárias, sociais, ambientais e econômicas. Essas equipes trabalham nos PA executando atividades como: elaboração de Planos de Desenvolvimento ou Recuperação de PA; acompanhamento e orientação técnica para as atividades produtivas e econômicas dos assentamentos; capacitação para assentados em diversos temas relacionados ao desenvolvimento rural; estímulo à organização social, apoiando o fortalecimento e qualificação das associações e outras formas organizativas dos assentados; promoção de ações afirmativas visando à equidade de gênero, geração, raça e etnia nos PA (INCRA, 2011).

O INCRA é responsável pela concessão de créditos aos assentados da Reforma Agrária, feita a partir do momento que um Projeto de Assentamento é criado ou reconhecido por essa autarquia. O primeiro crédito concedido aos assentados é o Crédito Instalação, que é concedido desde 1985 e seus valores e modalidades vêm sendo adequados ao longo dos anos.

${ }_{44}$ Assentamentos reconhecidos pelo INCRA são aqueles criados por outros órgãos ou autarquias, como os Institutos de Terras Estaduais, por exemplo, e são reconhecidos pelo INCRA para acesso aos créditos disponibilizados por esta autarquia. 
Com o objetivo de suprir as necessidades básicas, fortalecer as atividades produtivas, desenvolver os projetos, auxiliar na construção de suas unidades habitacionais e atender necessidades hídricas das famílias dos projetos de assentamento, o Crédito Instalação é concedido nas seguintes modalidades: Apoio Inicial, Aquisição de Material de Construção, Fomento, Adicional Semiárido, Recuperação de Materiais de Construção, Reabilitação de Crédito Produção. (INCRA, [2010], n.p.).

As modalidades, de acordo com o cronograma de concessão, valores e finalidades do Crédito Instalação são ${ }^{45}$ :

- Apoio Inicial (R\$ 3,2 mil por família), destinado à compra de alimentos, ferramentas, insumos, animais, etc., para o início do ciclo produtivo;

- Aquisição de Material de Construção (R\$ 15 mil por família), destinado à aquisição de materiais de construção, incluindo o pagamento de mão de obra e serviço técnico específico para a qualificação das habitações;

- Fomento (R\$ 3,2 mil por família), destinado à aquisição de insumos e ferramentas relativos à atividade produtiva;

- Adicional Semiárido (até R\$ 2 mil por família), destinado à implantação de obras que visem proporcionar segurança hídrica às famílias, soluções em captação, armazenamento e distribuição de água;

- Recuperação de Materiais de Construção (até R\$ 8 mil por família), destinado à melhoria das habitações, dado por laudo técnico individual e planilha orçamentária, com indicação da necessidade e dos valores para a reforma e/ou ampliação. A ampliação pode ser permitida nos casos de habitações com área construída igual ou inferior a $36 \mathrm{~m}^{2}$, ou quando o tamanho da família for incompatível com o tamanho da habitação. É permitido ainda na construção de banheiro, quando este for inexistente e em casos de desastres como ventanias, fogo ou enchentes;

45 Valores e condições dadas pelas normas de execução (NE) e instruções normativas (IN): NE ${ }^{\circ}$ 23/02 de 21 mar. 2002, NE n 79/08 de 26 dez. 2008, NE n 54/09 de 22 jul. 2009, NE $n^{\circ} 84 / 09$ de 03 set. 2009, NE $n^{\circ} 85 / 09$ de 21 set. 2009, NE n 86/09 de 04 nov. 2009, IN n 58/10 de 05 mar. 2010 e IN n ${ }^{\circ} 64 / 10$ de 21 out. 2010. (INCRA, [2010]). 
- Reabilitação de Crédito Produção (até R\$ 6 mil por família), destinada a recuperar a capacidade de acesso a novos créditos às famílias que contrataram financiamentos, exclusivamente, no âmbito do Programa Especial de Crédito para a Reforma Agrária (PROCERA), possibilitando quitação das dívidas contraídas.

Em 2008, foram criadas mais duas modalidades: Apoio Mulher ${ }^{46}$ (R $\$ 2,4$ mil por família) e o Adicional Fomento ${ }^{47}$ (R\$ 3,2 mil por família). Em 2009 foi criada a modalidade Crédito Ambiental ${ }^{48}$ (R\$ 2,4 mil por família).

Para o pagamento dos créditos, as normas de execução ${ }^{49}$ do INCRA definem prazo de financiamento de vinte anos, sendo o prazo de carência de três anos, seguido de dezessete prestações anuais e sucessivas. O prazo de carência é computado a partir da comprovação da aplicação dos recursos disponibilizados às famílias, e os pagamentos devem ser efetuados a partir do mês e do ano de vencimento do prazo de carência ${ }^{50}$.

A aplicação dos recursos é realizada com a participação de associações ou representantes dos assentados, orientados pelos técnicos de campo ou ATES na escolha e no recebimento dos produtos. O pagamento das aquisições é feito diretamente ao fornecedor (mercados locais e/ou lojas de material de construção) através da emissão de notas fiscais pagas pelo Banco do Brasil (BB).

Cada PA elege, através de ata em assembléia geral, três procuradores responsáveis pela abertura das contas no $\mathrm{BB}$, onde os valores de cada modalidade de crédito são depositados. Esses mesmos procuradores são responsáveis pela

46 O Apoio Mulher é concedido para utilização exclusiva da mulher titular do lote, aplicado em grupo, visando ao desenvolvimento de atividades agrícolas e/ou comerciais para promover a inserção e a participação das mulheres na dinâmica produtiva e econômica, bem como contribuir para a igualdade de gênero no meio rural.

${ }^{47} \mathrm{O}$ Adicional Fomento se destina a consolidar a segurança alimentar das famílias e o fortalecimento do processo de geração de excedente produtivo.

48 O Crédito Ambiental é destinado a financiar, durante dois anos, a implantação e o desenvolvimento de sistemas agroflorestais, para a recuperação de área de reserva legal.

49 Regulação dada pela NE n 79/08 de 26 dez. 2008 e NE n 86/09 de 04 nov. 2009. (INCRA, [2010]).

50 Incide sobre o valor dos créditos concedidos uma taxa de correção anual, desde que o pagamento ocorra dentro do prazo de vencimento. Para pagamento realizado fora dos prazos, incidirão outras taxas ainda. 
elaboração de três orçamentos para definição de onde se fará a compra. São também responsáveis pelo ateste das notas fiscais de cada família para pagamento.

A aplicação do Crédito é feita sob a supervisão dos técnicos de campo ou de ATES, que orienta o assentado na produção de uma lista de materiais ou insumos a ser orçada e adquirida. A aplicação do material adquirido, em tese, também é orientada pelos técnicos de campo ou ATES. Se uma família não aplicar os materiais adquiridos, está sujeita às sanções da lei, como sua exclusão do Programa de Reforma Agrária.

Além do Crédito Instalação, que beneficia as famílias individualmente, há o crédito Infraestrutura, destinado aos Projetos de Assentamento. As prioridades da concessão desse crédito são a construção e/ou a recuperação de estradas, implantação de sistemas de abastecimento de água e a construção de redes de eletrificação rural. Essas ações são executadas através de licitações públicas, ou por meio de convênios ou acordos celebrados com poderes executivos municipais e estaduais e com outras instituições governamentais da esfera federal, como o Ministério de Minas e Energia (no caso do Programa Luz para Todos), Fundação Nacional de Saúde (Funasa), entre outros. 


\section{Capítulo 03 - HABITAÇÃO RURAL - dos primeiros programas ao Minha Casa Minha Vida Rural}

\subsection{Habitação Rural - direito ou mercadoria?}

O modelo de desenvolvimento urbano brasileiro privou as faixas da população de menor renda de condições básicas de urbanidade, de cidadania e de inserção efetiva na cidade formal. Isto ocorreu porque o modelo de desenvolvimento urbano brasileiro foi impulsionado pela migração de um vasto contingente de pobres, associado à grande desigualdade de renda característica da sociedade brasileira, e à dominação de uma elite conservadora. Assim, cidades segregadas foram produzidas, marcadas de um lado por cidades formais, com espaços urbanos modernos, dotados de serviços e infraestrutura, e, por outro, por espaços suburbanos, negligenciados pelo Estado, sem serviços, sem infraestrutura, sem cidadania - a cidade informal -, ou ainda, a não-cidade.

Dessa forma, o planejamento territorial e os investimentos públicos de nossas cidades, centrados na cidade formal, aprofundaram a concentração de renda e a desigualdade social. O resultado é o tratamento da moradia, dos serviços e da infraestrutura urbana como mercadoria e não como bens e serviços indispensáveis ao direito humano à vida e à cidade. Trata-se de privilégios, e não de cidadania.

Da mesma forma, essas perversidades também se reproduzem no mundo rural. Basta recordarmos a dominação política do agronegócio em detrimento da agricultura familiar, e com maior gravidade ainda, em relação aos pobres rurais.

Mas cidadania nos remete ao conceito de "desenvolvimento como o processo de ampliação das capacidades dos indivíduos de fazerem escolhas", como definido por Amartya Sen. Então, a privação ou a restrição da liberdade individual afeta a capacidade humana de desenvolvimento. Assim, pobreza, fome, precariedade dos serviços de saúde, de saneamento básico, de habitação, falta de água tratada, 
subempregos ou desemprego, falta de educação, insegurança econômica e social afetam a capacidade de desenvolvimento do individuo. Nesse sentido, o acesso à moradia é visto como condição para a promoção das liberdades individuais, da ampliação do horizonte social da vida das pessoas, e, consequentemente, de desenvolvimento do país. Lembramos que o desenvolvimento aqui não se restringe a crescimento econômico.

A habitação é um direito fundamental desde 1948, segundo a Declaração Universal dos Direitos Humanos da Organização das Nações Unidas (ONU), artigo 25, ratificada pelo Brasil em 1992. Isso significa que a habitação é um direito humano universal, aceito e aplicável em todas as partes do mundo como um dos direitos essenciais para a vida das pessoas. Como tal, deve ser reconhecido, protegido e efetivado através de políticas públicas específicas. O seu não cumprimento significa uma violação da vida.

Vários tratados e convenções internacionais também protegem o direito à moradia, como o Pacto Internacional de Direitos Sociais, Econômicos e Culturais de 1966 (art. 11), a Declaração sobre Raça e Preconceito Racial de 1978 (art. 9), a Convenção sobre Eliminação de todas as Formas de Discriminação contra a Mulher de 1979 (art.14), a Convenção sobre os Direitos da Criança de 1989 (art. 27), entre outros. Instrumentos internacionais também tratam da moradia como um direito humano, tais como a Agenda 21 sobre Meio Ambiente e Desenvolvimento de 1992 e a Agenda Habitat de 1996.

No Brasil, a emenda constitucional $n^{\circ} 26$, de 14 de fevereiro de 2000, torna a moradia um direito social concebido e garantido pela Constituição Federal de 1988, em seu artigo $6^{\circ}$, caput (BRASIL, 1988b). Assim, o direito à moradia, ao lado da alimentação, figura no rol das necessidades mais básicas do ser humano, sendo dever do Estado assegurá-la a todos.

Contudo, é necessário a moradia ser digna. E por moradia digna, entende-se:

Respeitada a diversidade regional, cultural e física do país MORADIA DIGNA

tanto urbana como rural - deve necessariamente: 
Estar ligada às redes de infraestrutura (transporte coletivo, água, esgoto, luz, coleta de lixo, telefone, pavimentação);

Localizar-se em áreas servidas ou acessíveis por meio de transporte público - por equipamentos sociais básicos de educação, saúde, segurança, cultura e lazer;

Dispor de instalações sanitárias adequadas, e ter garantidas as condições mínimas de conforto ambiental e habitabilidade, de acordo com padrões técnicos.

Ser ocupada por uma única família (a menos de outra opção voluntária),

Contar com pelo menos um dormitório permanente para cada dois moradores adultos. (INSTITUTO CIDADANIA, 2000, p. 3).

É possível afirmar que os programas habitacionais no País, tanto urbanos como rurais, representam, quantitativamente, muito pouco diante das necessidades sociais, e qualitativamente redundaram em constantes fracassos, apenas favorecendo as camadas de renda média e alta, como veremos ao longo deste capítulo. Consequentemente, um grande número de pessoas de baixa renda não tem acesso a condições dignas de moradia nem pela via do mercado, e por essa razão passa a ser obrigação do poder público garantir políticas para que o direito à moradia digna seja implementado para todos.

Por conta de o déficit habitacional brasileiro ser majoritariamente urbano (85\% do total), restando à área rural aproximadamente 742 mil famílias que vivem em domicílios em condição de déficit em 2012 (Tabela 5), a habitação rural ganha pouco relevo na implementação de políticas públicas, e as alternativas para resolver sua problemática são quase inexistentes.

É relevante observar, a partir dos dados da Tabela 5, que nos últimos cinco anos o déficit urbano praticamente manteve-se estável, enquanto o rural diminuiu cerca de $25 \%$. Mas as habitações precárias, que representam menos de 10\% do déficit urbano total em 2012, no rural representam aproximadamente 70\% do déficit total no mesmo ano. Assim, mesmo com redução da precariedade habitacional, em valores absolutos, a precariedade rural segue maior (31\%) que a urbana. É importante também destacar que o déficit brasileiro continua a se concentrar nas faixas de renda mais baixas, calculado em 73,6\% na faixa de até 3 SM em 2012 (NETO; FURTADO; KRAUSE, 2013). 
Tabela 5 - Déficit habitacional geral e por componentes para áreas urbanas e rurais, 2007 a $2012^{51}$.

\begin{tabular}{lrrrrr}
\hline URBANO & $\mathbf{2 0 0 7}$ & $\mathbf{2 0 0 8}$ & $\mathbf{2 0 0 9}$ & $\mathbf{2 0 1 1}$ & $\mathbf{2 0 1 2}$ \\
\hline Numero de domicílios & $\mathbf{4 7 . 5 3 6 . 3 4 9}$ & 49.097 .569 & 50.044 .074 & 53.219 .429 & 54.446 .869 \\
Déficit Habitacional & 4.607 .176 & 4.278 .033 & 4.791 .825 & 4.548 .545 & 4.502 .572 \\
Precárias & 552.174 & 503.391 & 447.226 & 502.611 & 367.063 \\
Rústicos & 471.902 & 427.099 & 393.419 & 391.878 & 293.503 \\
Improvisados & 80.272 & 76.292 & 53.807 & 110.733 & 73.560 \\
Coabitação & 2.012 .094 & 1.743 .518 & 2.029 .079 & 1.599 .112 & 1.519 .713 \\
Cômodos & 195.860 & 162.943 & 204.685 & 225.384 & 159.891 \\
Conviventes com intenção de & & & & & \\
mudar & 1.817 .741 & 1.580 .575 & 1.827 .407 & 1.374 .909 & 1.360 .375 \\
Excedente aluguel & 1.756 .369 & 1.735 .474 & 2.020 .899 & 2.110 .409 & 2.293 .517 \\
Adensamento aluguel & 511.324 & 487.073 & 524.929 & 503.697 & 501.012 \\
\hline RURAL & $\mathbf{2 0 0 7}$ & $\mathbf{2 0 0 8}$ & $\mathbf{2 0 0 9}$ & $\mathbf{2 0 1 1}$ & $\mathbf{2 . 0 1 2}$ \\
\hline Numero de domicílios & 8.381 .689 & 8.605 .592 & 8.640 .529 & 8.250 .625 & 8.549 .663 \\
Déficit Habitacional & 986.015 & 913.532 & 911.178 & 860.665 & 741.953 \\
Precárias & 691.854 & 636.338 & 627.411 & 661.020 & 503.500 \\
Rústicos & 663.742 & 612.346 & 612.456 & 642.847 & 492.384 \\
Improvisados & 28.112 & 23.992 & 14.955 & 18.173 & 11.116 \\
Coabitação & 295.285 & 288.816 & 286.622 & 209.202 & 237.430 \\
Cômodos & 18.616 & 27.270 & 19.435 & 12.530 & 18.542 \\
Conviventes com intenção de & & & & & \\
mudar & 276.669 & 262.095 & 267.546 & 196.672 & 218.888 \\
Excedente aluguel & & & & & \\
Adensamento aluguel & 15.576 & 13.852 & 14.653 & 9.228 & 9.185 \\
\hline
\end{tabular}

Observação: o item "excedente de aluguel" não é calculado para as áreas rurais.

Fonte: NETO; FURTADO; KRAUSE, 2013, p.6.

Diante de tal quadro, torna-se fundamental a adoção de políticas que procurem melhorar as condições habitacionais e, consequentemente, a qualidade de vida no mundo rural, lembrando que devemos sim estender os serviços e direitos relativos à cidadania aos territórios rurais, ampliando a capacidade de escolha de seus sujeitos sociais, sem que para isso, esses territórios sejam transformados em áreas suburbanas ou em não-cidades.

51 Este estudo foi realizado mediante dados das Pesquisa Nacional por Amostra de Domicílios (PNAD) 2007, 2008, 2009, 2011 e 2012, reponderados a partir do Censo 2010, baseados na metodologia da Fundação João Pinheiro. 
Partimos do entendimento de que uma política de habitação rural não pode ser elaborada isoladamente, mas sim associada a uma política de desenvolvimento territorial. Por tanto, para alavancar o desenvolvimento rural brasileiro e eliminar a pobreza rural, são prioridades de políticas públicas para o Brasil rural atual, sendo essenciais seu incentivo e implementação: investimentos em infraestrutura, programas de garantia de renda e incentivos à habitação rural (DEL GROSSI; SILVA, 2002).

Os investimentos em infraestrutura e em programas de garantia de renda vêm sendo, aos poucos, tratados pelos governos com maior vigor nos últimos anos. Vale recordar o Programa Territórios da Cidadania, o PAA, PRONAF, e tantos outros programas já abordados anteriormente. Mas e a habitação rural?

O arcabouço legal da habitação rural no Brasil se inicia com a Constituição de 193452, que trazia, em seu Título IV, Da Ordem Econômica e Social, a criação de uma lei especial prevista para regulamentar o trabalho agrícola e as relações no mundo rural, em que "procurar-se-á fixar o homem no campo" (Art. 121, § 4º). Essa lei especial não chegou a se efetivar, mas este artigo da Constituição $\left(\S 5^{\circ}\right)$ referendou a política de colonização dos governos militares - as colônias agrícolas - que se seguiram até meados dos anos 1980.

Somente 30 anos depois, logo após o golpe militar de 1964, é sancionada a Lei da Habitação (Lei n $\left.{ }^{\circ} 4.380 / 1964\right)$, que “Institui a correção monetária nos contratos imobiliários de interesse social, o sistema financeiro para a aquisição da casa própria, cria o Banco Nacional da Habitação - BNH, e sociedades de crédito imobiliário, as letras imobiliárias, o Serviço Federal de Habitação e Urbanismo e dá outras providências". Em seu Capítulo I - Da Coordenação dos Órgãos Públicos e da Iniciativa Privada, a Lei traz:

52 Importante destacar que nesta mesma Constituição (Art. 125) aparece pela primeira vez um artigo relativo a usucapião, que garantia direito aos posseiros (BRASIL, 1934). Este artigo só se altera na Constituição de 1946, (Título V, Da Ordem Econômica e Social, Art. 156), que além de garantir direitos aos posseiros, passa a limitar o tamanho da área de usucapião, mas garante a propriedade, não mais apenas "o domínio do solo". 
Art. $1^{\circ}$ O Governo Federal, através do Ministro de Planejamento, formulará a política nacional de habitação e de planejamento territorial, coordenando a ação dos órgãos públicos e orientando a iniciativa privada no sentido de estimular a construção de habitações de interesse social e o financiamento da aquisição da casa própria, especialmente pelas classes da população de menor renda.

[...]

Art. $4^{\circ}$ Terão prioridade na aplicação dos recursos:

$[\ldots]$

$\mathrm{V}$ - a construção de moradia a população rural. (BRASIL, Lei $\mathrm{n}^{\circ} 4.380$, de 21 de agosto de 1964).

Essa Lei surge como o marco da institucionalização da política habitacional no nível federal e é a primeira lei a incluir de fato alguma referência à habitação rural. $\mathrm{O}$ que vinha sendo tratado até este momento pelas Constituições brasileiras - em termos de habitação rural - referia-se apenas a posse, domínio ou propriedade da terra. Isso porque o acesso à moradia rural se confunde com o acesso à propriedade, e como a casa se assenta sobre o solo, confunde-se, ainda, com acesso à terra.

Muitas críticas são feitas à produção habitacional de pouco mais de 20 anos do BNH como, por exemplo, a padronização dos conjuntos implantados, desprezando a qualidade do projeto arquitetônico, a não inserção urbana, além da sua atuação exclusivamente urbana. Mas do ponto de vista quantitativo, os resultados das ações urbanas desenvolvidas pelo BNH foram positivas, porém, ainda assim insuficientes para suprir o déficit habitacional urbano do País.

A estratégia da política habitacional da era BNH favoreceu a construção civil, mas pouco fez para "estimular a construção de habitações de interesse social e o financiamento da aquisição da casa própria, especialmente pelas classes da população de menor renda", como previa a Lei. Isto ocorreu porque não era possível incorporar práticas alternativas, de baixo custo, já que o sistema se baseava única e exclusivamente na produção da casa própria. A não utilização de subsídios e a adoção do sistema de financiamento bancário também contribuíram para a exclusão da população de renda mais baixa dessa política habitacional.

Depois do fim do governo militar, o BNH é extinto, e a Caixa Econômica Federal passa a absorver algumas de suas atribuições, pessoal e acervo. Assim, iniciase uma fase da "política" habitacional brasileira, pós-BNH, que deixa de ter uma 
estratégia nacional, e Municípios, Estados e a União passam a lançar programas habitacionais com fontes alternativas de recursos (recursos orçamentários), utilizando práticas tradicionais da população mais pobre, como o mutirão, o que promove melhor inserção urbana, e elaborando projetos de maior interesse urbanístico.

Com o fim do BNH, perdeu-se uma estrutura de caráter nacional que,
mal ou bem, tinha acumulado enorme experiência na área, formado
técnicos e financiado a maior produção habitacional da história do
país. A política habitacional do regime militar podia ser equivocada,
como já ressaltamos, mas era articulada e coerente. Na
redemocratização, ao invés de uma transformação, ocorreu um
esvaziamento e pode-se dizer que deixou propriamente de existir
uma política nacional de habitação. Entre a extinção do BNH (1986) e
a criação do Ministério das Cidades (2003), o setor do governo federal
responsável pela gestão da política habitacional esteve subordinado a
sete ministérios ou estruturas administrativas diferentes,
caracterizando descontinuidade e ausência de estratégia para
enfrentar o problema. (BONDUKI, 2008, p. 75- 76).

Em 1988, a Carta Magna tornou competência comum da União, dos Estados, do DF e dos Municípios "promover programas de construção de moradias e a melhoria das condições habitacionais e de saneamento básico", nos termos de seu artigo 23, inciso IX. O poder local se consolida como o maior interlocutor das organizações populares e o responsável pelo equacionamento das demandas sociais, acentuando a tendência de descentralização dos programas habitacionais. Observa-se, a partir de então, diversas experiências: desde intervenções tradicionais, processos participativos e autogestionários, até parcerias com a sociedade organizada (BONDUKI, 2008).

Também na Constituição Federal de 1988, o Capítulo III - Da Política Agrícola e Fundiária e da Reforma Agrária, em seu Artigo 187, traz em seu enunciado que a política agrícola será planejada e executada levando em conta, especialmente, dentre outros fatores, a habitação para o trabalhador rural. No entanto, como vimos, a habitação rural continua figurando apenas (quando são figuradas) no enunciado das leis. 
No início dos anos 90, a Lei no 8.171/1991, que dispõe sobre a Política Agrícola, traz um capítulo exclusivo para a habitação rural (Capítulo XX), com dois artigos importantes, mas que, novamente, figuram apenas no enunciado da Lei.

Art. 87. É criada a política de habitação rural, cabendo à União destinar recursos financeiros para a construção e/ ou recuperação da habitação rural.

$\S 1^{\circ}$ Parcela dos depósitos da Caderneta de Poupança Rural será destinada ao financiamento da habitação rural.

[...]

Art. 89. O Poder Público estabelecerá incentivos fiscais para a empresa rural ou para o produtor rural, nos casos em que sejam aplicados recursos próprios na habitação para o produtor rural. (BRASIL, Lei no 8.171, de 17 de janeiro de 1991).

Em 1995, o governo de Fernando Henrique Cardoso "retoma" a política habitacional (urbana) criando programas de financiamento voltados ao beneficiário final - Carta de Crédito FGTS (Fundo de Garantia do Tempo de Serviço) Individual e Associativa, com destaque para o financiamento de material de construção e a aquisição de imóveis usados.

Contudo, o programa de aquisição de imóveis usados não gera empregos nem atividade econômica, e a modalidade material de construção, com seu baixo valor de financiamento, tende a estimular a produção informal da moradia, sem assessoria técnica e com dificuldades em alcançar condições adequadas de habitabilidade. Assim, não foi possível alavancar uma nova política habitacional e o resultado foi um conjunto de efeitos perversos, do ponto de vista social, econômico e urbano (BONDUKI, 2008).

Com a predominância dessas duas modalidades de crédito, uma visão bancária do financiamento habitacional foi consolidada no País, sendo a Caixa o único agente financeiro a operar os recursos destinados à habitação, priorizando a concessão de créditos em condições de maior garantia e de mais fácil acompanhamento. Logo constata-se o favorecimento às camadas de renda média e alta. As camadas de baixa 
renda, incluindo aí as famílias rurais pobres, mais uma vez foram pouco, ou quase nada, beneficiadas ${ }^{53}$.

É possível observar que desde a Constituição de 1934, em que se afirma que “procurar-se-á fixar o homem no campo", passando pela lei de 1964, na qual "o governo formulará a política nacional de habitação, dando prioridade", entre outros itens, “à habitação rural”, somente em 1991 uma lei específica para a habitação rural é criada. Mesmo com esse aparato legal, a habitação rural para famílias de baixa renda no Brasil vinha sendo executada, até 2003, apenas no âmbito da Política Nacional de Reforma Agrária, via concessão de créditos do INCRA, mais especificamente através do Crédito Instalação, nas modalidades: Aquisição de Material de Construção e Recuperação de Materiais de Construção (PRA).

A modalidade Aquisição é acessada quando o Apoio Inicial ${ }^{54}$ estiver aplicado por, pelo menos, 75\% dos beneficiários do Programa Nacional de Reforma Agrária de determinado assentamento e não houver pendências nas prestações de contas totais ou parciais do PA, segundo normativa do INCRA. Esse crédito destina-se à aquisição exclusiva de material de construção e é acessada quando do ingresso da família na Reforma Agrária via assentamento ou reconhecimento de assentamento.

A modalidade Recuperação também é para compra exclusiva de materiais de construção e é acessada somente após a finalização da aplicação da modalidade Aquisição. A não ser por força de tragédias (enchentes, fogo, ventanias, etc.), a modalidade Recuperação é acessada apenas uma vez por família. Vale lembrar aqui que os créditos de habitação concedidos pelo INCRA se resumem a listas de material de construção formuladas por agrônomos ou técnicos agrícolas.

53 Segundo BONDUKI (2008) o Programa Carta de Crédito Individual, entre 1995 e 2002, destinou 28,6\% dos recursos para a faixa de mais de 10 salários mínimos (SM), 50,15\% dos recursos para a faixa entre 5 a $10 \mathrm{SM}, 15,1 \%$ para a faixa entre 3 a $5 \mathrm{SM}$, e apenas $6,2 \%$ dos recursos foram destinados para famílias na faixa de até $3 \mathrm{SM}$.

54 Cf. Capítulo 2. Apoio Inicial: primeira modalidade de crédito instalação concedida aos assentados da Reforma Agrária (R \$ 3,2 mil por família) destinado à compra de alimentos, ferramentas, insumos, animais, etc., para o início do ciclo produtivo. 


\subsection{Programas de Habitação Rural}

Os programas de habitação rural no Brasil têm suas origens em dezembro de 2000 (Tabela 6), quando foi assinado um convênio entre a Caixa Econômica Federal e o INCRA, para construção de habitações nos Assentamentos de Reforma Agrária, que beneficiou 30 mil famílias do Centro Oeste e Nordeste do País. Os recursos eram oriundos do Programa Carta de Crédito - FGTS (CC-FGTS), Operações Coletivas aquisição de material de construção - garantia caução. Nas operações comuns dessa modalidade, é disponibilizado um financiamento ao beneficiário, que deve aportar uma caução à Caixa, em dinheiro, para garantir o investimento. A diferença nas operações com o INCRA é que a caução era aportada pelo INCRA, com recursos do OGU (Orçamento Geral da União). Em 2001, esse benefício foi estendido às famílias rurais das regiões Sul e Sudeste, englobando um total de 411 municípios do País atendidos.

Esse convênio com o INCRA representa um marco importante, pois, pela primeira vez, desde a inclusão do trabalhador rural no FGTS em 1988, os recursos desse fundo são destinados às famílias rurais. É também a primeira vez que a Caixa opera programas habitacionais no mundo rural.

Em 2002, um projeto piloto de habitação rural no Rio Grande do Sul, com recursos do PSH (Programa de Subsídio à Habitação de Interesse Social) e do FGTS, deu início ao PSH Rural, que foi implantado em todo o País em 2003.

O PSH foi criado em 2002, com o objetivo de subsidiar o financiamento de casas populares, complementando a capacidade de pagamento dos beneficiários. É operado com recursos provenientes do OGU e conta, ainda, com o aporte de contrapartida proveniente dos estados, DF e municípios, sob a forma de complementação aos subsídios oferecidos pelo programa, o que possibilita reduzir o custo médio de cada unidade. 
Tabela 6 - Programas de Habitação Rural no Brasil a partir do ano 2000.

\begin{tabular}{|c|c|c|c|c|c|c|c|c|c|}
\hline Ano & Programa & Local & $\begin{array}{l}\text { Valor } \\
\text { disponi- } \\
\text { bilizado }\end{array}$ & Parceiros & Recursos & $\begin{array}{c}\text { Contrapartida/ } \\
\text { Caução } \\
\text { (Parceiros) }\end{array}$ & Pagamento & $\begin{array}{c}\text { Beneficiá- } \\
\text { rios }\end{array}$ & $\begin{array}{l}\text { Unids. } \\
\text { execu- } \\
\text { tadas }\end{array}$ \\
\hline 2001 & $\begin{array}{l}\text { CC-FGTS - } \\
\text { Op. } \\
\text { Coletivas }\end{array}$ & $\begin{array}{l}\text { Centro- } \\
\text { Oeste e } \\
\text { Nordeste } \\
\text { Sul e } \\
\text { Sudeste }\end{array}$ & $\begin{array}{l}\text { Até R\$ } \\
2.500,00\end{array}$ & INCRA & $\begin{array}{c}\mathrm{R} \$ 2.500,00 \\
\text { (FGTS) }\end{array}$ & INCRA & INCRA & Assentados & $62.310155 .775 .000,00$ \\
\hline 2002 & $\begin{array}{c}\text { PSH } \\
\text { Rural } \\
\text { (Programa } \\
\text { Piloto) }\end{array}$ & $\begin{array}{l}\text { Rio } \\
\text { Grande do } \\
\text { Sul }\end{array}$ & $\mathrm{R} \$ 7.500,00$ & $\begin{array}{c}\text { CRENHOR*, } \\
\text { MPA*, Gov. }^{*} \text { do Estado } \\
\left(\mathrm{AGF}^{*}\right)\end{array}$ & $\begin{array}{c}\mathrm{R} \$ 4.500,00 \\
(\mathrm{OGU})+\end{array}$ & $\begin{array}{c}\text { doação de } \\
\text { terreno, } \\
\text { infraestrutura }\end{array}$ & $\begin{array}{l}\text { Beneficiários: } \\
\text { até } 20 \text { anos, } \\
\text { taxas anuais }\end{array}$ & $\begin{array}{l}\mathrm{AFs}^{*} \text { com } \\
\text { renda até } \\
\mathrm{R} \$ 240,00\end{array}$ & $4.506 .545,86$ \\
\hline $\begin{array}{l}2002 \\
\text { até } \\
2005\end{array}$ & PSH Rural & $\begin{array}{l}\text { Todo o } \\
\text { País }\end{array}$ & & $\begin{array}{l}\text { govs. } \\
\text { estaduais e } \\
\text { municipais }\end{array}$ & (FGTS) & $\begin{array}{c}\text { assistência } \\
\text { técnica }\end{array}$ & anos de & $\begin{array}{l}\text { AFs com } \\
\text { renda até } \\
\mathrm{R} \$ 740,00\end{array}$ & $7.422 \quad 16.824 .740,14$ \\
\hline 2004 & $\begin{array}{l}\text { CC-FGTS - } \\
\text { Op. } \\
\text { Parcerias }\end{array}$ & $\begin{array}{l}\text { Todo o } \\
\text { País }\end{array}$ & $\begin{array}{l}\text { Até R\$ } \\
7.000,00\end{array}$ & $\begin{array}{c}\text { govs. } \\
\text { estaduais, } \\
\text { municipais e } \\
\text { assossiações } \\
\text { ou } \\
\text { coooperativas }\end{array}$ & $\begin{array}{c}\mathrm{R} \$ 4.500,00 \\
(\mathrm{OGU})+ \\
\mathrm{R} \$ 2.500,00 \\
\quad(\mathrm{FGTS})\end{array}$ & $\begin{array}{c}\text { doação de } \\
\text { terreno, } \\
\text { infraestrutura } \\
\text { ou prestação de } \\
\text { assistência } \\
\text { técnica }\end{array}$ & $\begin{array}{l}\text { Beneficiários: } \\
\text { até } 8 \text { anos, } \\
\text { taxas anuais } \\
\text { de } 6 \text { a } 8,16 \%, \\
1 \text { ano de } \\
\text { carência. }\end{array}$ & $\begin{array}{l}\text { AFs com } \\
\text { renda até } \\
\mathrm{R} \$ 1.200,00\end{array}$ & $43.715399 .499 .907,00$ \\
\hline
\end{tabular}

\section{Observações:}

\section{*CRENHOR: Cooperativa de Crédito Novos Horizontes de Novo Sarandi}

*MPA: Movimento dos Pequenos Agricultores

\section{*AGF: Agência Gaúcha de Fomento}

\section{*AF: Agricultores Familiares}

\section{Fonte: elaboração própria.}

A novidade do PSH Rural refere-se a organização dos beneficiários por uma entidade privada sem fins lucrativos ${ }^{55}$, consolidada através do Termo de Cooperação e Parceria, firmado entre a Caixa e a associação de beneficiários, em que se define o grau de participação dos envolvidos, a obrigatoriedade de assistência técnica e no qual se permite apresentar novos projetos arquitetônicos, sem padronizações.

Esse programa foi executado até 2005, e foram atendidas 9.410 famílias rurais em todo o Brasil, num valor total de obra de R\$ 21.331.286,00. Eram disponibilizados $\mathrm{R} \$ 7,5$ mil, e desse valor, $\mathrm{R} \$ 4,5$ mil eram de natureza não onerosa. O restante deveria ser pago pelo beneficiário dentro de $20 \operatorname{anos}^{56}$.

55 As contratações urbanas do PSH são organizadas pelos governos dos estados, DF ou municípios.

56 Com taxas anuais de 1,15\% e 3 anos de carência. (BRASIL, [2011a]). 
Em 2003, o Governo Federal iniciou o Programa Nacional de Habitação Rural (PNHR) reunindo estas duas iniciativas de programas de habitação rural, o PSH Rural e a CC-FGTS - Operações Coletivas. Em 2004, o Crédito Solidário - FDS (Fundo de Desenvolvimento Social) é somado às modalidades de contratação do PNHR (Tabela 7).

Tabela 7 - Modalidades de contratos PNHR 2003 a 200957.

\begin{tabular}{|c|c|c|c|c|}
\hline & Programa PSH & $\begin{array}{c}\text { Programa CC- } \\
\text { FGTS } \\
\text { Operações } \\
\text { Coletivas } \\
\end{array}$ & $\begin{array}{c}\text { Programa CC- } \\
\text { FGTS } \\
\text { Operações } \\
\text { Coletivas } \\
\end{array}$ & $\begin{array}{c}\text { Programa } \\
\text { Crédito Solidário }\end{array}$ \\
\hline Modalidade & $\begin{array}{c}\text { Leilão } \\
\text { Subsidiado }\end{array}$ & $\begin{array}{l}\text { Caução (fundo } \\
\text { perdido) }\end{array}$ & Financiamento & Financiamento \\
\hline Recursos & $\begin{array}{c}\text { Variam entre } R \$ \\
2.000 \text { e } R \$ 4.500 \\
\text { por família }\end{array}$ & $\begin{array}{c}\mathrm{R} \$ 5.907 \\
\text { (subsidiado) }\end{array}$ & $\begin{array}{c}\mathrm{R} \$ 3.000 \\
\text { (subsidiado) }\end{array}$ & $\begin{array}{l}\mathrm{R} \$ 10.000 \text { para } \\
\text { construção e } \\
\mathrm{R} \$ 7.500 \text { para } \\
\text { reforma }\end{array}$ \\
\hline Contrapartida & $\begin{array}{l}\text { Oferecida por } \\
\text { municípios ou } \\
\text { estados, que } \\
\text { poderá ser } \\
\text { cobrada dos } \\
\text { beneficiários }\end{array}$ & $\mathrm{R} \$ 2.093$ & $\begin{array}{c}\mathrm{R} \$ 6.000 \\
\text { (financiado) }\end{array}$ & $\begin{array}{l}\text { Não há, portanto } \\
\text { o recurso é todo } \\
\text { financiado }\end{array}$ \\
\hline $\begin{array}{c}\text { Público } \\
\text { Alvo }\end{array}$ & $\begin{array}{l}\text { Agricultores com } \\
\text { renda até } \mathrm{R} \$ 465 \\
\text { mensais }\end{array}$ & $\begin{array}{l}\text { Agricultores } \\
\text { com renda de } \\
\text { até } 1 \text { salário } \\
\text { mínimo }\end{array}$ & $\begin{array}{c}\text { Agricultores } \\
\text { com renda de } \\
\text { R\$ } 930 \text { a R\$ } \\
1.500\end{array}$ & $\begin{array}{l}\text { Agricultores com } \\
\text { renda de até } 3 \\
\text { salários mínimos }\end{array}$ \\
\hline $\begin{array}{l}\text { Prazo de } \\
\text { devolução }\end{array}$ & $\begin{array}{l}\text { Varia conforme } \\
\text { proposta da } \\
\text { entidade } \\
\text { promotora, até } \\
72 \text { meses }\end{array}$ & $\begin{array}{l}\text { Não há prazo } \\
\text { de devolução }\end{array}$ & Até 96 meses & 240 meses \\
\hline $\begin{array}{l}\text { Fonte de } \\
\text { Recursos }\end{array}$ & $\begin{array}{c}\text { Banco Central do } \\
\text { Brasil }\end{array}$ & FGTS & FGTS & FDS \\
\hline
\end{tabular}

Fonte: ROVER; MUNARINI, 2010, p. 263, adaptado para este trabalho.

O PNHR visava atender famílias com renda entre um e três SM via programas que exigiam contrapartida financeira dos beneficiários. A ideia inicial era beneficiar

57 Os dados desta tabela se baseiam no Decreto Federal n 6.819 de 13 de abril de 2009, a última alteração deste formato do PNHR. 
6.300 famílias assentadas em programas de Reforma Agrária e pequenos agricultores. O investimento foi estimado em R\$ 54,575 milhões, com recursos do OGU, FGTS, estados, DF, municípios e cooperativas habitacionais (BRASIL, 2003a).

Segundo ROVER e MUNARINI (2010) “entre 2003 e 2006 foram assinados mais de 17 mil contratos beneficiando as famílias agricultoras do meio rural no Brasil, com mais de R\$ 140 milhões" investidos, mas "mais de 63\% das famílias inscritas no PNHR não foram contempladas", o que nos mostra a magnitude da demanda e a importância desse programa de habitação para famílias rurais de baixa renda.

O Programa CC-FGTS foi reformulado em 2004, através da Resolução $n^{\circ} 460$ (BRASIL, 2004a) do Conselho Curador do FGTS, que definiu novas condições para o Programa, o que possibilitou a formalização de novas operações em parcerias no mundo rural.

Esse novo modelo da Carta de Crédito considerou a diversidade dos custos de produção e aquisição de imóveis de acordo com o porte e localização dos municípios, e definiu que quanto menor fosse a renda da família beneficiária, maior seria seu subsídio contratado.

A resolução permite financiamentos ou concessão de subsídios para as áreas de habitação $\operatorname{popular}^{58}$ no Programa Operações Coletivas ${ }^{59}$, que visa atender às necessidades habitacionais das famílias de baixa renda, com atendimento direto às pessoas físicas, organizadas de forma coletiva, em parceria com uma Entidade Organizadora (EO). O sistema de obras definido por esse programa é o mutirão ou a autoconstrução assistida ${ }^{60}$.

58 A resolução também permite financiamentos ou empréstimos nas áreas de habitação ou operações especiais, saneamento básico e infraestrutura urbana. (BRASIL, [2009a]).

59 O Programa Operações Coletivas apresenta as seguintes modalidades de financiamento: 1. Aquisição de terreno e construção de imóvel residencial urbano; 2. Construção de imóvel residencial urbano em terreno próprio; 3. Aquisição de Imóvel Novo ou Usado; 4. Aquisição de Lote Urbanizado; e 5. Aquisição de Material de Construção (construção, reforma e/ou ampliação).

60 Tanto no sistema de mutirão quanto no de autoconstrução assistida é necessário supervisionamento do canteiro de obras. A diferença é que no mutirão várias famílias 
Para imóvel rural, é possível contratação na modalidade Aquisição de Material de Construção - garantia caução, o que significa que a EO deve aportar um valor como contrapartida ao financiamento. Também é possível a contratação via modalidade Operações Parcerias, que se diferencia da Coletiva, pois a contrapartida da EO pode ser dada em bens ou serviços, como doação de terrenos, infraestrutura ou prestação de assistência técnica.

A EO tem como responsabilidade organizar o grupo de beneficiários e promover e/ou produzir as unidades habitacionais, urbanas ou rurais em intervenções sob a forma concentrada ou pulverizada. São consideradas EO: cooperativas, associações, condomínios, sindicatos, entidades privadas sem fins lucrativos, Poder Público Estadual e Municipal, companhias de habitação, pessoas jurídicas voltadas à produção de unidades habitacionais e também o INCRA ou Institutos de Terras Estaduais.

Por fim, a terceira e última modalidade de contratação nessa formatação do PNHR era o Crédito Solidário61, que foi criado em 2004, e foi o primeiro programa federal voltado exclusivamente à autogestão habitacional, por meio de cooperativas e associações como EO, operando recursos do FDS. O Programa visa atender famílias com renda bruta mensal até $\mathrm{R} \$ 1.125^{62}$, em que a produção habitacional (rural ou urbana) se dá por autoconstrução ou autogestão (a cargo das EO decidirem). Suas modalidades são: aquisição de imóvel novo; aquisição de terreno e construção; construção; e conclusão, reforma e/ou ampliação63.

constroem várias habitações e na autoconstrução é a própria família quem constrói a sua habitação.

61 A Resolução $n^{\circ}$ 93, de 28 de abril de 2004, do Conselho Curador do FDS, Cria o Programa Crédito Solidário voltado para o atendimento de necessidades habitacionais de famílias de baixa renda, organizados em cooperativas ou associações com fins habitacionais. (BRASIL, 2004b).

62 O Programa admite, excepcionalmente, contratações de famílias com renda até R\$ 1.900 .

63 Os financiamentos não têm incidência de juros, a contrapartida mínima é de $5 \%$ do valor de investimento e o limite de avaliação do imóvel é de até $\mathrm{R} \$ 72.000,00$. Para a aquisição de imóvel novo, aquisição de terreno e construção, construção e aquisição de material de construção, os valores são: até R \$ 30.000,00 (região metropolitana RJ/SP); até R\$ 24.000,00 (demais regiões metropolitanas); até $\mathrm{R} \$$ 18.000,00 (municípios com mais de 50 mil 
Por ser um programa de financiamento, os beneficiários devem retornar integralmente o valor do investimento em até 20 anos ao fundo. Os recursos do FDS são privados e onerosos, mas é um fundo em processo de extinção, devido à inexistência de alternativas para sua realimentação financeira (IPEA, 2011). O fundo continua operando ainda hoje no Programa Minha Casa Minha Vida, e sua alimentação financeira é dada por aportes da União. Convém lembrar que o processo seletivo regular para contratações do Crédito Solidário está suspenso atualmente, e seleções de propostas pelo Ministério das Cidades (MCidades) só ocorrem em âmbito "excepcional".

Às restrições financeiras enfrentadas pelo FDS juntam-se as dificuldades das entidades organizadoras para elaborar projetos e atender os requisitos do programa, além dos desafios enfrentados pelo agente financeiro, a CAIXA, na operação de um programa que exige inovação em sua prática herdada do $\mathrm{BNH}$, de relação exclusiva com empresários, poder público e companhias habitacionais. Soma-se a isto também um sistema normativo pouco adaptado à execução direta por entidades da sociedade civil de recursos orçamentários habitacionais.

A execução das obras, por sua vez, também se mostra penosa e em prazos mais longos que os inicialmente previstos, em razão do pouco conhecimento sobre gestão de empreendimentos habitacionais demonstrado por associações e cooperativas habitacionais populares - ao passo que os valores de financiamento são bastante limitados, não se admitindo equívocos ou desperdícios em sua aplicação. Em consequência, do total de empreendimentos contratados até 4 de julho de 2008, apenas $60 \%$ encontravam-se finalizados ou com mais de $90 \%$ das obras executadas até 30 de abril de 2009. (IPEA, 2011, p. 21- 22).

Apesar de todas as dificuldades enfrentadas pelo Crédito Solidário, é importante ressaltar seu pioneirismo ao propor as contratações direta e exclusivamente com entidades habitacionais privadas, sem fins lucrativos. Diferente da CC-FGTS Operações Coletivas em que a EO deve promover e/ou produzir as unidades habitacionais (UH), no Crédito Solidário é a EO quem deve promover e produzir as UH. Essa iniciativa deu origem ao Programa Habitacional Popular Entidades (PHPE), no âmbito do Programa Minha Casa, Minha Vida.

habitantes); e até $\mathrm{R} \$ 12.000,00$ (demais municípios e área rural). Na conclusão, ampliação e/ou reforma: $\mathrm{R} \$ 7.500,00$ para municípios com até 50 mil habitantes e área rural; e R\$ 10.000,00 para os demais municípios. (BRASIL, [2009a]). 
Essa formatação do PNHR via PSH Rural, CC-FGTS Operações Coletivas e Crédito Solidário - FDS durou até 2009, quando através de diversos decretos e portarias, novas regras foram instituídas, que apresentavam mudanças significativas: além de ampliar a faixa de subsídio, exigiam menos contrapartida das famílias mais vulneráveis socioeconomicamente, mas excluía os beneficiários da Reforma Agrária. Era o início do Programa Minha Casa Minha Vida (PMCMV), do qual o PNHR se tornou um subprograma, também conhecido como Minha Casa Minha Vida Rural64. Nesse mesmo ano de 2009, os valores dos créditos para habitação do INCRA foram aumentados: a modalidade Aquisição de Material de Construção saltou de R\$ 5 mil para R\$ 15 mil, e o PRA foi de R\$ 3 mil para R\$ 8 mil por família.

O PMCMV compreende os seguintes subprogramas:

- Programa Nacional de Habitação Urbana (PNHU): específico para o atendimento de famílias com renda familiar bruta mensal de até R\$ 5.000,00;

- PNHR (ou PMCMV Rural): específico para o atendimento de famílias rurais com renda familiar bruta anual de até $\mathrm{R} \$$ 60.000,00; e

- PHPE: atende a beneficiários de baixa renda nas áreas urbanas, organizados de forma associativa por uma EO.

Na primeira fase do PMCMV (2009 a 2011), a meta era a construção ou reforma de um milhão de habitações, com investimentos de $\mathrm{R} \$ 34$ bilhões para famílias com renda de zero a dez SM. Na sua segunda fase, a meta passa a ser a construção de dois milhões de residências no País até o final de 2014, sendo 60\% delas direcionadas a famílias da faixa de renda mais baixa, com um investimento de $\mathrm{R} \$ 71,7$ bilhões.

A Caixa era o principal agente financeiro e gestor operacional dos recursos do PMCMV, sendo que na primeira fase do programa o BB atuava exclusivamente nas faixas de renda entre 3 e 10 SM do PNHU. A partir de janeiro de 2012, o BB teve a sua participação ampliada no programa, passando a atuar no PNHU na faixa de renda de

${ }^{64} \mathrm{O}$ nome PMCMV Rural não é oficial, mas o adotaremos aqui para diferenciar as fases do PNHR antes e depois de 2009, quando foi instituído o Programa Minha Casa Minha Vida. 
até R\$1.600,00, atual Faixa 1 (denominada até 3 SM na primeira fase do Programa), e também no PMCMV Rural.

A partir da segunda fase do programa, valores nominais para as faixas de renda foram adotados, abandonando as faixas dadas pelos salários mínimos. Isso porque, nos últimos anos, a atuação do governo promoveu uma forte recuperação do salário mínimo, o que distorce fortemente a utilização desse indicador para fixar as faixas de atendimento (BONDUKI, 2009).

O PNHR se tornou um subprograma do PMCMV através Medida Provisória $\mathrm{n}^{\circ}$ 459, de 25 de março de 2009, convertida na Lei $n^{\circ} 11.977$, de 07 de julho de 2009, modificado mais tarde pela MP $n^{\circ} 510 / 2010$, convertida na Lei $n^{\circ} 12.424$, de 16 de junho de 201165. A Lei do PMCMV designa que o PNHR tem por finalidade “criar mecanismos de incentivo à produção ou reforma de habitações rurais", para os agricultores familiares e trabalhadores rurais, por intermédio de operações de repasse de recursos do OGU (subsídio) ou de financiamento habitacional com recursos do FGTS.

Os beneficiários do Programa são Agricultores Familiares (definidos pela Lei $\mathrm{n}^{\mathrm{o}}$ 11.326, de 24 de julho de 2006), trabalhadores rurais e ainda assentados do Programa Nacional de Reforma Agrária ${ }^{66}$ com renda mensal bruta anual de até R $\$ 60.000,00$, segundo três grupos de renda (Tabela 8). Os beneficiários devem ser organizados de forma coletiva por EO de caráter público ou privado, em grupos de no mínimo 4 e no máximo $50 \mathrm{UH}^{67}$.

65 Desde sua instituição em 2009, o PMCMV passou por várias regulamentações via Decretos e Portarias Interministeriais, sendo a Portaria do MCidades n ${ }^{\circ}$ 194, de 30 de abril de 2013, a última publicada. (BRASIL, [2013b]).

66 Incluídos pela Portaria Interministerial n 78 de 8 de fevereiro 2013 (Ministério das Cidades/ Ministério do Planejamento, Orçamento e Gestão/ Ministério do Desenvolvimento Agrário).

67 Com exceção dos beneficiários do Grupo 3, cujo acesso poderá se dar de forma individual e ainda dos assentados de Reforma Agrária que poderão formar grupos com mais de $50 \mathrm{UH}$. 
Tabela 8 - PNHR ou PMCMV Rural: Grupos de contratações, valores, prazos.

\begin{tabular}{|c|c|c|c|c|}
\hline & & Grupo G1 & Grupo G2 & Grupo G3 \\
\hline & $\begin{array}{l}\text { Renda Familiar } \\
\text { Anual }\end{array}$ & Até $\mathrm{R} \$ 15.000,00$ & $\begin{array}{c}\text { Entre } R \$ 15.000,01 \\
\text { a } R \$ 30.000,00\end{array}$ & $\begin{array}{c}\text { Entre } \mathrm{R} \$ 30.000,01 \\
\text { a } \mathrm{R} \$ 60.000,00\end{array}$ \\
\hline & Prazo pagamento & 4 anos & $\begin{array}{l}\text { Entre } 5 \text { e } \\
10 \text { anos }\end{array}$ & $\begin{array}{l}\text { Entre } 5 \text { e } \\
10 \text { anos }\end{array}$ \\
\hline & Prestação & $\begin{array}{l}\text { 4\% do subsídio } \\
\text { em } 4 \text { parcelas } \\
\text { anuais, sem } \\
\text { juros e sem } \\
\text { atualização } \\
\text { monetária, } \\
\text { carência } 1 \text { ano }\end{array}$ & $\begin{array}{l}\text { Anual ou } \\
\text { Semestral }\end{array}$ & $\begin{array}{l}\text { Anual ou } \\
\text { Semestral }\end{array}$ \\
\hline \multirow{4}{*}{ 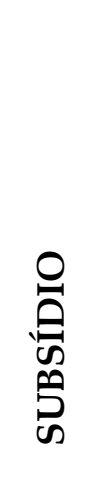 } & Taxa & Não se aplica & $\begin{array}{c}5 \% \text { a } 5,11 \% \\
\text { ao ano }\end{array}$ & $\begin{array}{c}6 \% \text { a } 7,39 \% \\
\text { ao ano }\end{array}$ \\
\hline & Propostas & Via EO & Via EO & $\begin{array}{l}\text { Via EO ou } \\
\text { individual }\end{array}$ \\
\hline & Construção & Até $\mathrm{R} \$ 25.000$ & \multirow{2}{*}{$\begin{array}{c}\mathrm{R} \$ 7.610,00 \\
\text { (complemento } \\
\text { recursos FGTS) }\end{array}$} & \multirow[b]{2}{*}{ Não há } \\
\hline & $\begin{array}{l}\text { Conclusão/ } \\
\text { Reforma/ } \\
\text { Ampliação }\end{array}$ & Até $\mathrm{R} \$ 15.000$ & & \\
\hline \multirow{6}{*}{ 至 } & & Até $\mathrm{R} \$ 28.500,00$ & \multirow{4}{*}{$\begin{array}{c}\text { Mínimo } \\
\text { R\$ 6.000,00 } \\
\text { e Máximo } \\
\text { R\$30.000,00 }\end{array}$} & \multirow{4}{*}{$\begin{array}{c}\text { Mínimo } \\
\text { R\$ 20.000,00 } \\
\text { e Máximo } \\
\text { R\$ 60.000,00 }\end{array}$} \\
\hline & Construção & $\begin{array}{c}\text { Região Norte até } \\
\mathrm{R} \$ 30.500,00\end{array}$ & & \\
\hline & & Até R\$ 17.200,00 & & \\
\hline & Reforma & $\begin{array}{l}\text { Região Norte até } \\
\text { R\$18.400,00 }\end{array}$ & & \\
\hline & $\begin{array}{l}\text { Recursos } \\
\text { destinados } \\
\text { à EO }\end{array}$ & $\begin{array}{c}\mathrm{R} \$ 400,00 \\
\mathrm{ATEC}^{*}+ \\
\mathrm{R} \$ 200,00 \mathrm{TS}^{*}\end{array}$ & $\begin{array}{c}\mathrm{R} \$ 600,00 \text { ATEC }+ \\
\mathrm{R} \$ 400,00 \text { TS (OGU) }\end{array}$ & Não há \\
\hline & $\begin{array}{l}\text { Fonte de } \\
\text { Recursos }\end{array}$ & OGU & FGTS e OGU & FGTS \\
\hline
\end{tabular}

Observação:

*ATEC (Assistência Técnica);

*TS (Trabalho Social).

Nos casos de reforma, o valor limite de avaliação do imóvel após a intervenção proposta não pode ultrapassar a $R \$ \mathbf{6 5 . 0 0 0 , 0 0}$ para operações do $G 1$, e $R \$ \mathbf{9 0 . 0 0 0 , 0 0}$ para operações dos Grupos 2 e 3, conforme manual do FGTS.

Fonte: Elaboração própria. 
O PMCMV Rural estabelece as categorias de agricultores beneficiários conforme as regras do PRONAF. Isso agiliza processos e aproveita uma sistemática consolidada há anos para distribuição das categorias de agricultores entre os grupos de contratação do programa. Para as contratações dos assentados de Reforma Agrária, o INCRA é o responsável pela seleção e hierarquização da demanda a ser repassada, por intermédio da Relação de Beneficiários (RB), à Entidade Organizadora. É o INCRA que atesta a comprovação da renda dos beneficiários que se enquadram no grupo 1 do PMCMV Rural.

Estão excluídos do programa: quem já foi beneficiado anteriormente em programas de habitação social do Governo Federal68; proprietários, cessionários, ou promitentes compradores de imóvel residencial ou detentores de financiamento habitacional ativo em qualquer localidade do território nacional; quem possui débitos não regularizados junto à Receita Federal; quem estiver inserido no Cadastro Informativo de Créditos não Quitados do Setor Público Federal (CADIN); e o proprietário de área superior a quatro módulos fiscais.

O regime construtivo das moradias rurais pode ser: mutirão assistido, autoconstrução assistida, administração direta ou empreitada global ${ }^{69}$. Mas deverá ser adotado um único regime construtivo para o grupo contratado.

A novidade desse novo formato do PNHR é a obrigatoriedade de acompanhamento da execução das obras por representantes dos beneficiários nas contratações dos grupos 1 e 2. Assim, o programa estabelece a criação de uma Comissão de Representantes (CRE) formada por no mínimo três integrantes, que

68 Salvo os assentados da Reforma Agrária que já obtiveram Crédito Instalação nas modalidades Aquisição de Materiais de Construção ou Recuperação de Materiais de Construção, que nestes casos só poderão ter acesso à modalidade Reforma.

69 Mutirão assistido: regime de construção em que os beneficiários produzem conjuntamente as unidades habitacionais com o auxílio de assistência técnica especializada (engenheiro, mestre de obras, pedreiro, eletricista e outros profissionais afins); autoconstrução assistida: o beneficiário, titular do contrato, produz sua unidade habitacional com o auxílio de assistência técnica especializada; administração direta: a EO é diretamente responsável pela execução das obras, além de utilizar mão-de-obra do seu quadro de funcionários ou a ela vinculado; empreitada global: uma construtora é contratada para a execução da obra ou do serviço por preço certo e total. A empresa gerencia a execução do empreendimento e a CRE fiscaliza a sua atuação. 
devem ser eleitos em assembleia, registrada em ata, sendo dois eleitos dentre os beneficiários participantes do projeto e um representante indicado pela EO. Cabe à CRE a gestão dos recursos financeiros, a prestação de contas aos demais beneficiários, e a coordenação do conjunto da obra.

Outra inovação importante do PMCMV Rural trata do trabalho social (TS), que é de responsabilidade da EO e deve ser executado em três etapas: até 3 meses na etapa pré-obras; até 12 meses na etapa execução de obras e até 3 meses na etapa pósocupação. Para tanto são destinados às EO R\$ 400,00 por contrato dos grupos 1 e 2 (recursos OGU). Para os beneficiários do Grupo 3 é dispensada a execução dessas atividades de trabalho social. A grande inovação aqui é o trabalho social executado nas etapas pré e pós-ocupação.

O TS é um conjunto de ações inclusivas, de caráter socioeducativo, que tem como objetivo promover o exercício da participação cidadã, favorecendo a organização da população e a gestão comunitária dos espaços comuns, na perspectiva de contribuir para fortalecer a melhoria da qualidade de vida das famílias e a sustentabilidade dos empreendimentos. Deve ser desenvolvida junto aos beneficiários, por profissionais com formação compatível ${ }^{70}$, a partir do estudo e diagnóstico das características familiares de cada grupo contratado 71 e deverá contemplar, no mínimo, ações e cronograma financeiro e de execução em relação a: fomento à organização comunitária visando à autonomia e a gestão democrática dos processos implantados; ações voltadas à organização comunitária; educação ambiental; planejamento e gestão do orçamento familiar; apoio à geração de trabalho e renda; e apoio à gestão condominial.

70 Profissionais com formação compatível são aqueles com formação superior na área de Ciências Humanas e experiência comprovada em trabalhos com comunidades ou grupos sociais.

${ }^{71} \mathrm{O}$ escopo do TS deverá contemplar a orientação para a regularização fundiária em parceria com a Defensoria Pública nos casos de beneficiários que se enquadrem em: agricultores familiares e trabalhadores rurais na condição de posseiros de terras públicas, ocupantes de terras particulares com direitos sucessórios pendentes de partilha ou posseiros de boa fé, ocupantes de terras particulares há mais de 5 anos, guardadas as devidas precauções legais. 
Nessa mesma linha, o PMCMV Rural estabelece como atribuições das EO: gerenciar as obras e serviços necessários à consecução do objeto dos contratos firmados no âmbito do PNHR, responsabilizando-se pela sua conclusão e adequada apropriação das obras e serviços pelos beneficiários finais.

Outra grande novidade é que constitui diretriz do PMCMV Rural o atendimento às famílias do Grupo 1 sem acesso a solução de abastecimento de água, em conjunto com o Programa Cisternas, do Ministério de Desenvolvimento Social e Combate à Fome (MDS). Isto significa que as famílias enquadradas no Grupo 1, localizadas em regiões afetadas por estiagens prolongadas ou onde o abastecimento de água seja irregular não garantindo a segurança alimentar, serão atendidas com a construção de cisternas pelas EO para o armazenamento da água da chuva, com recursos provenientes do $\mathrm{MDS}^{72}$. As cisternas poderão ser construídas concomitantemente às modalidades de construção e de reforma do PMCMV Rural, ou como complementação dessas operações já finalizadas.

Outra parceria relevante que o PMCMV Rural estabelece, nesse mesmo sentido de promover a aderência entre diversos programas sociais, é com o MDA, através de contratações prioritárias para municípios inseridos nos Programas Territórios da Cidadania e Brasil Sem Miséria (MDS).

Importante também é destacar o atendimento prioritário do PMCMV Rural às famílias com mulheres responsáveis pela unidade familiar, a idosos e pessoas com deficiência, a posseiros, comunidades tradicionais e às famílias em situação de emergência ou calamidade pública, além do programa não estabelecer idade máxima para os beneficiários do G173.

Assim como no Programa CC-FGTS, o PMCMV Rural considera a diversidade dos custos de produção e aquisição de imóveis de acordo com o porte e localização

72 As cisternas podem ser construídas em ferrocimento (malha de aço revestida por tela metálica e cimento) ao custo de $\mathrm{R} \$ 2.860$, solução mais adequada às regiões sul, ou em placas de argamassa armada ao custo de $\mathrm{R} \$ 2.020$, solução mais adequada às regiões do semiárido ou nordeste. (BRASIL, [2013a]).

73 Para os Grupos 2 e 3, por se tratar de financiamento, a idade do beneficiário mais velho, somada ao prazo de financiamento não deve ultrapassar 80 anos, 5 meses e 29 dias. 
dos municípios, e assim estabelece um valor adicional às contratações em função do custo logístico para a região Norte.

Por fim, mais uma novidade do PMCMV Rural é a distribuição das metas e recursos do programa de acordo com a participação de cada região no déficit habitacional rural do país, segundo dados da Pesquisa Nacional por Amostra de Domicílios - PNAD, e IBGE, referentes ao ano de 2007 e suas atualizações ${ }^{74}$.

As metas para o período de 2011 a 2014 do PMCMV Rural estão distribuídas conforme a Tabela 9, sendo que no mínimo $25 \%$ da meta física global deverá contemplar contratações na modalidade conclusão/ reforma ou ampliação.

Tabela 9 - Distribuição de metas físicas PNHR 2011 a 2014.

\begin{tabular}{cc}
\hline Região & UH \\
\hline Centro-Oeste & 5.470 \\
Norte & 15.606 \\
Nordeste & 78.804 \\
Sudeste & 11.018 \\
Sul & 9.102 \\
Brasil & $\mathbf{1 2 0 . 0 0 0}$ \\
\hline
\end{tabular}

Fonte: BRASIL, 2013b.

Para as contratações de assentados de Reforma Agrária, as metas físicas de contratação para o período de 2013 a 2014 são de 70.000 UH, que serão distribuídas regionalmente pelo INCRA, de acordo com sua prioridade de atendimento. Segundo MDA, foram identificados 909 assentamentos prioritários no País com demanda por moradias, inseridos na área de abrangência do Plano Brasil Sem Miséria e que já possuam estradas de acesso e sistemas de abastecimento de água, ou projetos para a sua implantação.

Como resultados (parciais é claro) do PMCMV Rural, podemos apresentar: até fevereiro de 2013, foram entregues 17,5 mil moradias, e ainda já foram contratadas outras 46,3 mil moradias em áreas rurais de todo o País. (Brasil, 2013c).

${ }^{74}$ Cf. Portaria Interministerial Ministério das Cidades/ Ministério da Fazenda ${ }^{\circ} 326$, de 31 de agosto de 2009, Art. $4^{\circ}$ (BRASIL, 2009c). 


\section{Capítulo 04 - EXPERIÊNCIAS DE HABITAÇÃO RURAL.}

\subsection{A contribuição de universidades e movimentos sociais.}

A partir do ano 2000, alguns programas de habitação rural surgiram no Brasil, em função de bem sucedidas parcerias entre a Caixa Econômica Federal, o INCRA, movimentos sociais e cooperativas de agricultores familiares. Mas até 2003, com o lançamento do PNHR em sua primeira versão, esses programas se constituíam de iniciativas isoladas, baseadas sempre em adaptações à realidade rural de programas habitacionais urbanos já existentes operacionalizados pela Caixa.

Além dessas iniciativas, que se transformaram nos primeiros programas de habitação rural, outras ainda podem ser constatadas a partir do ano 2000. Trata-se de parcerias entre INCRA, movimentos sociais e universidades que se constituíram em importantes experiências. Muitas não tiveram abrangência nacional, mas se configuram como um importante aprendizado no processo de construção, se não de uma Política Pública de Habitação Rural no Brasil, ao menos do Programa Minha Casa Minha Vida Rural em operação nos dias de hoje.

A primeira experiência a ser destacada vem do Rio Grande do Sul e é uma parceria entre INCRA e UFRGS (Universidade Federal do Rio Grande do Sul). O INCRA e o Governo do Estado do Rio Grande do Sul passaram a construir uma política de assentamento compartilhado, em que o INCRA passou a reconhecer a titularidade dos assentamentos de Reforma Agrária criados pelo Governo do Estado para terem acesso aos seus créditos, em especial aos referentes à habitação. Dessa forma, passaram a executar o Programa de Habitação Rural nos assentamentos federais e estaduais de Reforma Agrária, a partir do ano 2000, somando os recursos do INCRA aos recursos e assistência técnica do Governo do estado.

O convênio com a universidade surge a partir das dificuldades que o Programa de Habitação enfrentava, o que levou o INCRA a procurar a Universidade com a 
intenção de formar uma parceria para acompanhar e avaliar os projetos que estavam em andamento e os que ainda seriam implantados até 2003. O objetivo era criar uma proposta para aperfeiçoar o Programa, diminuindo alterações dos projetos arquitetônicos ${ }^{75}$, identificar possíveis causas de abandono de lotes, e introduzir técnicas e materiais alternativos de construção. A parceria durou até 2005, atuando em 72 municípios do Estado do Rio Grande do Sul, e beneficiou aproximadamente 9.100 famílias de 230 PA.

A novidade dessa experiência vem do acompanhamento na execução das obras feito pela Universidade, a fim de aperfeiçoar o Programa de Habitação. Na verdade, a Universidade funcionou como uma assessoria técnica, o que garantiu a qualidade das intervenções. Outra novidade importante é a inserção de equipamentos, técnicas e materiais alternativos de construção ${ }^{76}$, o que barateia o custo da unidade além de conferir maior pertencimento aos beneficiários no processo de construção de suas habitações.

Também vindo do sul, outra iniciativa importante a se destacar é da Cooperhaf (Cooperativa de Habitação dos Agricultores Familiares dos Três Estados do Sul), que desde 2001 atua no Rio Grande do Sul, a partir de 2004 em Santa Catarina, de 2006 no Paraná e depois por todo o País, e ainda está em atuação nos dias de hoje.

A Cooperhaf promove a habitação rural para cooperados do sistema SINTRAF (Sindicatos dos Trabalhadores na Agricultura Familiar) / CUT (Central Única dos Trabalhadores), via PSH Rural e Programa Carta de Crédito FGTS, modalidade Operações Coletivas - Parcerias. Na modalidade Parceria, a contrapartida da cooperativa é feita através de prestação de assistência técnica. Já os beneficiários arcam com o pagamento dos valores do financiamento do FGTS, além de taxas da

75 As alterações se davam, pois os beneficiários modificavam seus projetos originais executando outros serviços ou ampliações que não estavam previstos projeto original, o que causava aumento do custo da execução e dificultava o término da obra.

76 Técnicas e materiais alternativos de construção, específicos para essa experiência: paredes em terra crua executadas em superadobe, tijolos de adobe, sanitário seco, cobertura em telhado vivo, estufa e cisterna em ferrocimento. 
cooperativa. Segundo dados da Cooperhaf, até abril de $2011^{77}$ já haviam sido contratados 31.687 UH em todo o País, dentre os programas PSH Rural e Programa Carta de Crédito FGTS.

Essa experiência tem destaque, pois a prestação de assistência técnica feita pela cooperativa não se limita a questões técnicas de obra, mas abrange acompanhamento e discussão antes das contratações, e até um mês após a obra concluída, de assuntos como: autoconstrução, saneamento básico e utilização racional dos resíduos das obras; cooperativismo, sindicalismo e organização comunitária local; ambiente saudável e sustentável, produção orgânica, cuidados com fontes de água limpa e lixo doméstico; relações sociais e gestão financeira do lote/ propriedade. Ou seja, trata-se da execução de um trabalho social.

Outra experiência relevante aconteceu em Goiás, em 2003. Após debater por três anos a organização territorial do Assentamento Canudos, em fase de implantação, com 329 famílias, o MST procura o INCRA e a UFG (Universidade Federal de Goiás) para firmar uma parceria para a elaboração do Plano de Desenvolvimento do Assentamento (PDA).

O plano foi realizado em 2003 numa parceria entre UFG, INCRA e MMA (Ministério do Meio Ambiente). A habitação nesse assentamento contou apenas com recursos do INCRA, mas o projeto tanto das casas, quanto da construção foi discutido junto com o PDA, o que trouxe bastante qualidade ao assentamento implantado, criando um "zoneamento ambiental”, e também às casas produzidas, que incorporaram práticas tradicionais como, por exemplo, o fogão à lenha.

Apesar de não se configurar como um programa de habitação, essa iniciativa revela a importância da inter-relação e aderência entre organização territorial, infraestrutura e equipamentos sociais, meio ambiente, produção, cooperação, organização política e social, cultura e memória, educação e saúde na construção de um território. Ou seja, mostra a importância da compreensão de que a habitação

77 Informações obtidas em palestra no evento II Colóquio Habitat e Cidadania Habitação Social no Campo. Realização: HABIS - IAU/USP; UFSCar; GERAH - UFRN e USINA. São Carlos - SP. Maio/2011. 
rural não pode ser elaborada isoladamente, mas sim associada ao desenvolvimento territorial.

Outra parceria importante a se destacar vem do Nordeste. Desde 2002, o GERAH (Grupo de Estudos em Reforma Agrária e Habitat da Universidade Federal do Rio Grande do Norte) atua nos assentamentos de Reforma Agrária do estado do Rio Grande do Norte, em parceria com o INCRA, prestando assistência técnica em $4.416 \mathrm{UH}^{78}$, com acompanhamento político frequente do MST. O GERAH é um grupo interdisciplinar, formado por professores e alunos de arquitetura, ciências sociais, educação, antropologia, geografia, engenharia civil, tecnologia e educação do campo. Aqui mais uma vez, a Universidade funciona como uma equipe técnica de monitoramento não só de obra, mas também de execução de trabalho social.

Por fim, a última experiência a ser destacada ocorreu no estado de São Paulo, em 2005, onde as lideranças de um assentamento procuram o INCRA para viabilizar um Acordo de Cooperação e Parceria com a Caixa, o que originou o Programa de Moradia Rural INCRA/SP. Esse programa será melhor detalhado mais adiante, mas agora nos interessa saber que foram contratadas 3.068 intervenções entre construção e reforma no estado de São Paulo, com recursos do FGTS.

É importante observar que o INCRA está quase sempre envolvido nas iniciativas relatas. Isso se deve, principalmente, ao fato dos beneficiários de Reforma Agrária contarem apenas com recursos do INCRA para habitação, e por isso mesmo concentram suas pressões nesta Instituição, forçando-a a criar soluções.

Mas o mais relevante dessas iniciativas deve-se às atuações das universidades, no caso do GERAH, onde a universidade procura o INCRA, e dos movimentos sociais, casos de Goiás e São Paulo, onde o movimento procura o INCRA. Dessa forma, constata-se que a questão da habitação rural vem passando por um incremento em termos de qualidade, e é cada vez mais frequente a busca por assessoria técnica, mesmo com poucos recursos. E ainda há o caso da Cooperhaf, em

${ }^{78}$ Cf. nota 77. 
que, independente do INCRA, o movimento social procura diretamente o agente financiador.

Todas essas experiências nos mostram a consolidação de algumas práticas e o abandono de outras na construção do PMCMV Rural executado desde 2009. Para melhor compreender este processo, analisaremos mais de perto a experiência destacada em São Paulo.

\subsection{O Programa Moradia Rural INCRA/SP.}

Em 2005, um Grupo de Extensão Universitária da FAU - USP (Faculdade de Arquitetura e Urbanismo da Universidade de São Paulo) ${ }^{79}$ inicia a discussão sobre o “sonho da casa" no Assentamento Estadual (PE) 80 Dom Tomás Balduíno, no município de Franco da Rocha - SP. Paralelamente às discussões acerca da moradia, o movimento social desse assentamento inicia uma busca por recursos para a construção desses sonhos. No final de 2005, o superintendente do INCRA/SP é procurado pelas lideranças daquele PE, que solicitam documentos que viabilizariam uma possível contratação de financiamento para habitação que a Caixa disponibilizaria ao mundo rural.

O Superintendente, então, se interessou pela contratação e iniciou os trâmites com a Caixa no sentido de viabilizar aquele financiamento a outros assentamentos do estado de São Paulo. Após meses de negociações, e várias versões de um Acordo entre as autarquias, em 2006, o INCRA/SP e a Caixa assinam um Acordo de Cooperação e Parceria, no âmbito da resolução 460/2004 do Conselho Curador do

${ }^{79}$ Grupo coordenado pelo professor Dr. Reginaldo Ronconi.

80 Os assentamentos estaduais são criados pelo ITESP - Fundação Instituto de Terras do Estado de São Paulo "José Gomes da Silva". O ITESP é a entidade responsável pelo planejamento e execução das políticas agrária e fundiária do Estado de São Paulo, destinando terras públicas estaduais para o assentamento de trabalhadores rurais sem terra, assim como o reconhecimento das Comunidades de Quilombos. É vinculada à Secretaria de Estado da Justiça e da Defesa da Cidadania. (SÃO PAULO, [2012]). 
FGTS, para viabilizar moradias dignas aos beneficiários da Reforma Agrária no estado de São Paulo.

Iniciava-se assim o Programa de Moradia Rural INCRA/SP, que veio fortalecer a divisão de Desenvolvimento de Assentamentos e passou a atuar como uma modalidade de Crédito Instalação.

A versão final do Acordo, assinada em 02 de agosto de 2006, estabelece que as contratações se deem no âmbito do Programa Carta de Crédito Individual - FGTS, na forma coletiva, modalidade Aquisição de Material de Construção, garantia caução, destinado à construção ou reforma/melhoria de unidades habitacionais rurais.

Esse Acordo trata exclusivamente das contratações em que o INCRA/SP é a EO dos empreendimentos contratados, e assim estabelece que as condições para a contratação sejam: existência mínima de infraestrutura nos assentamentos (ou de previsão orçamentária e de planejamento para sua realização), o recebimento de Crédito Instalação pelos beneficiários e a aprovação pela Caixa do cadastro dos beneficiários apresentados pelo INCRA/SP81.

O Crédito Instalação seria a contrapartida da contratação, ou seja, a garantia caução da EO. Mas essa caução, no caso específico do Acordo Caixa X INCRA/SP, não foi utilizada de fato como contrapartida, e sim disponibilizada integralmente para a compra de materiais de construção, fruto de uma adaptação no sistema da Caixa em uma modalidade de contratação já existente. Dessa forma, as contratações se deram a "fundo perdido", ou seja, sem o pagamento de contrapartida pela EO tão pouco pelos beneficiários. Mas, no sistema da Caixa esses valores eram entendidos como contrapartida da EO.

${ }^{81}$ Após este trâmite é celebrado um Termo de Cooperação e Parceria próprio para cada PA, e ainda, cada assentado deve assinar um contrato individual com a Caixa. 
No caso do Crédito Instalação já aplicado pelo beneficiário, seria adotado um ateste de material aplicado pelo INCRA/SP. Para os casos dos créditos ainda não aplicados, esses recursos deveriam ser transferidos para as contas abertas na Caixa ${ }^{82}$.

O Acordo também define que não é possível a transferência de recursos entre os beneficiários contratados, e que novas contratações poderão ser suspensas, porém, as que estiverem em andamento deverão ser liquidadas.

Sobre as responsabilidades da EO, o Acordo define que o INCRA/SP deveria contratar e manter durante a vigência do Acordo $^{83}$ uma equipe qualificada de engenheiros e arquitetos, com experiência comprovada na execução de obras pelo sistema de mutirão e autoconstrução assistida, denominada Equipe Técnica de Monitoramento. Definia, ainda, que o INCRA/SP deveria elaborar relatórios técnicos periódicos e fotográficos por empreendimento contratado, informando o andamento das obras à Caixa.

Das obrigações da Caixa, o Acordo prevê que esta efetue vistorias por amostragem em cada assentamento, correspondendo a no mínimo 5\% das unidades contratadas por visita, para a constatação do andamento das obras - e se não for constatada evolução da obra, a Caixa pode bloquear o repasse do recurso até a normalização da situação.

A estrutura organizacional do programa se deu com a participação dos seguintes atores: o INCRA/SP no papel de EO; a Caixa como fiscalizadora das obras e gestora do recurso; três procuradores de cada assentamento, devidamente eleitos em assembleia, representando os assentados; uma Equipe Técnica de Monitoramento, denominada Equipe de Moradia Rural (EMR), subordinada à EO; e por fim, os assentados como beneficiários e mutirantes.

82 Para o caso de outras EO, o pagamento da garantia caução é obrigatório, assim como era no caso do primeiro acordo de cooperação entre Caixa e INCRA, via Carta de Crédito, modalidade aquisição de material de construção, firmado em 2000 e depois 2001 . No caso da contratação com o INCRA/SP, não havia esta obrigatoriedade - por conta da adaptação feita no sistema da Caixa.

${ }^{83}$ Data de vigência do Acordo: 36 meses de sua publicação - a vigência terminaria em agosto de 2009. 
A implantação do Programa exigiu grande mobilização de diversos atores, justificada pelo grande número de contratações, além, é claro, das grandes distâncias entre os PA e mesmo entre os lotes dentro dos assentamentos. Assim, os técnicos de campo do INCRA/SP (ATES), os escritórios regionais ${ }^{84}$ e a Unidade Avançada $(\mathrm{UA})^{85}$, os assentados, as lideranças e principalmente a EMR precisavam se organizar e atuar como uma grande equipe para a execução do programa.

A EMR foi composta por arquitetos e engenheiros que seriam responsáveis pela supervisão, coordenação técnica das obras e elaboração das peças técnicas necessárias à contratação e a execução das obras. Ou seja, a Equipe era responsável pela elaboração dos projetos e orçamentos ${ }^{86}$ das $U H$ novas e das reformas ou ampliações; pelo acompanhamento e elaboração dos documentos necessários à contratação; pelo planejamento, implementação e viabilização das obras, e ainda pela organização dos grupos contratados e treinamento da mão de obra mutirante (Imagem 1).

Inicialmente, a EMR ficou subordinada ao Gabinete, tratando diretamente com o Superintendente Substituto (responsável pelo Acordo com a Caixa). Mais tarde, foi subordinada à Divisão de Desenvolvimento de Assentamentos.

No início do programa a Equipe contava com três arquitetos, um engenheiro e um administrativo. Depois das contratações, em 2007, somaram-se à equipe um arquiteto e dois administrativos lotados nos escritórios de Promissão e de Andradina. Em 2008, a equipe contou com seu maior número: eram seis arquitetos e

${ }^{84}$ Os escritórios Regionais do INCRA/SP ou Núcleos de Apoio estão localizados em: Araraquara, Bauru, Iaras, Itapeva, Mirante do Paranapanema, Presidente Epitácio, Promissão, Rancharia, Ribeirão Preto, Teodoro Sampaio, Vale do Paraíba (Taubaté), Vale do Ribeira (Apiaí), Eixo Anhanguera e Itapetininga.

85 As Unidades Avançadas são órgãos descentralizados, porém não independentes, de caráter transitório, subordinado às SR. Em todo o País há cerca de 70 UA. A UA de São Paulo se localiza em Andradina (a 630 km da Capital) e foi inaugurada em 2008, com o propósito de prestar melhor assistência à grande área de assentamentos que aquela região concentra.

${ }^{86} \mathrm{O}$ Acordo determinava que os orçamentos fossem baseados nos custos dados pelo SINAPI (Sistema Nacional de Pesquisa de Custos e Índices da Construção Civil). As informações do SINAPI resultam de trabalhos técnicos da Caixa e do IBGE, que pesquisa mensalmente preços de materiais, de equipamentos de construção e de salários, em todas as capitais dos estados. O SINAPI calcula custos para projetos residenciais, comerciais, equipamentos comunitários, saneamento básico, emprego e renda urbana e rural. 
quatro administrativos. Já em 2009, a antiga Equipe foi totalmente substituída por uma nova que contava com um engenheiro, quatro técnicos em edificações ${ }^{87}$ e os dois administrativos de Promissão e Andradina.

Infelizmente, a Equipe foi reestruturada por diversas vezes, o que dificultava a continuidade das ações. Em particular, a substituição da antiga Equipe por uma totalmente nova em 2009 prejudicou muito o andamento do programa.

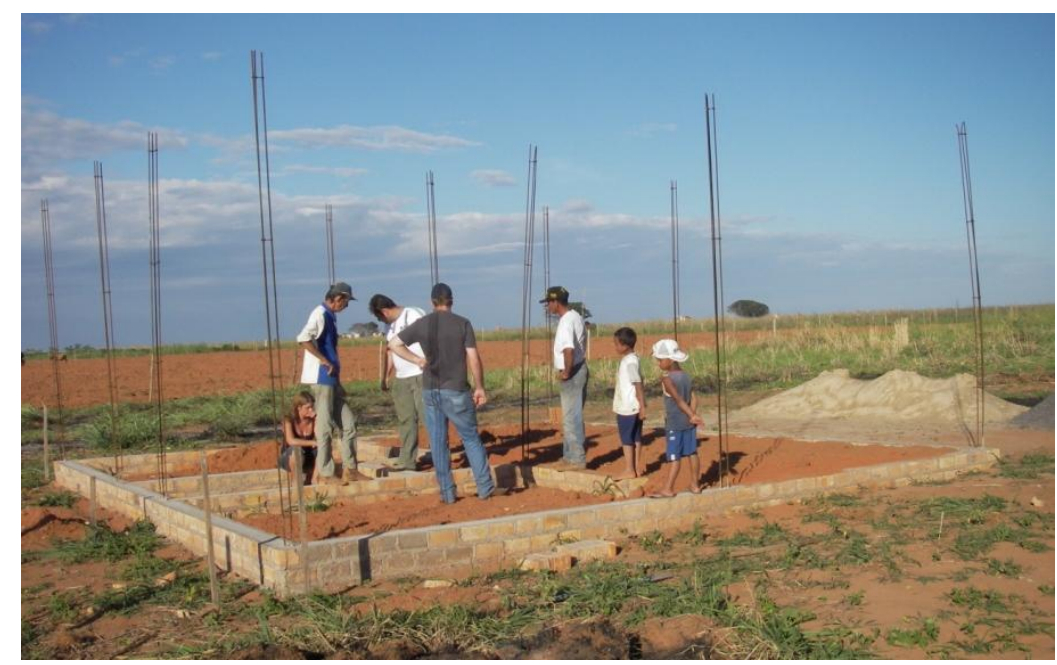

Figura 1 - EMR orientando assentados.

Arquiteto da Equipe de Moradia Rural (em pé, segundo da esquerda para a direita) orientando assentados do PA Dandara, Promissão - SP, na aplicação do Crédito Instalação, modalidade Aquisição de materiais (R\$ 5 mil).

Fonte: Acervo Moradia Rural, dez. 2007.

Para as contratações, era necessário realizar os orçamentos de acordo com os recursos disponíveis - subsídio e contrapartida ou caução da EO. De acordo com as normativas sobre o Programa CC-FGTS Operações Coletivas, o valor de subsídio a ser contratado para cada beneficiário varia conforme o tamanho do município onde o

87 É importante salientar que os técnicos em edificações, segundo o CREA, não podem se responsabilizar pelas obras da Moradia Rural devido ao seu porte - número de unidades contratadas. Assim, é necessário que haja, pelo menos, um arquiteto ou engenheiro civil na Equipe. 
empreendimento se encontra ${ }^{88}$. Também a renda familiar de cada beneficiário altera o valor de subsídio. Assim, para as contratações com o INCRA/SP, foi estabelecido que a renda familiar de todos os assentados a pleitearem o crédito seria de duzentos até trezentos e cinquenta reais, atestada pelo INCRA/SP, o que geraria maior valor de subsídio.

Para complementar os recursos, entra a contrapartida ou caução da EO, dada em muitos casos em ateste de material aplicado. Alguns assentamentos tiveram seus valores do Crédito Instalação transferidos para a Caixa. Mas, ao longo do processo, o INCRA/SP, numa decisão política, resolve aplicar os recursos disponíveis no BB, e interrompe as transferências para a Caixa.

Segundo as normativas do INCRA, o Crédito Instalação Modalidade Aquisição dispunha, em 2006, do valor de R 5.000,00, e a Modalidade PRA R \$3.000,00. Assim, a tabela 10 mostra os valores máximos para contratação.

Tabela 10 - Valores máximos das contratações Programa Moradia Rural INCRA/SP.

\begin{tabular}{cccc}
\hline $\begin{array}{c}\text { TAMANHO DO } \\
\text { MUNICÍPIO }\end{array}$ & $\begin{array}{c}\text { RECURSOS } \\
\text { FGTS } \\
\text { (subsídio) }\end{array}$ & $\begin{array}{c}\text { RECURSOS INCRA } \\
\text { (Crédito Instalação ou PRA) }\end{array}$ & $\begin{array}{c}\text { VALOR } \\
\text { TOTAL DA } \\
\text { OBRA }\end{array}$ \\
\hline $\begin{array}{c}\text { RMSP } \\
\text { Mais de 100 Mil } \\
\text { habitantes } \\
\begin{array}{c}\text { Menos de } 100 \text { mil } \\
\text { habitantes } \\
\text { RMSP }\end{array}\end{array}$ & $\mathrm{R} \$ 11.990,00$ & $\mathrm{R} \$ 3.000,00$ & $\mathrm{R} \$ 14.990,00$ \\
$\begin{array}{c}\text { Mais de 100 mil } \\
\text { habitantes }\end{array}$ & $\mathrm{R} \$ 5.990,00$ & $\mathrm{R} \$ 3.000,00$ & $\mathrm{R} \$ 11.990,00$ \\
$\begin{array}{c}\text { Menos de } 100 \text { mil } \\
\text { habitantes }\end{array}$ & $\mathrm{R} \$ 11.990,00$ & $\mathrm{R} \$ 3.000,00$ & $\mathrm{R} \$ 8.990,00$ \\
\hline
\end{tabular}

Fonte: Equipe de Moradia Rural, fev. 2006.

Como em muitos casos os recursos do INCRA/SP já estavam aplicados nas moradias, tínhamos, de fato, muitas contratações que contavam apenas com os

${ }^{88}$ Essa variação de valores de subsídio por tamanho de município é dada pela lógica adotada pela Caixa de que quanto maior é o município, mais altos são os preços de material de construção e mão de obra praticados ali. 
valores do FGTS. Assim, a variedade de valores contratados no estado foi grande, mas a maior parte das obras foi contratada apenas com o valor do subsídio, ou seja, $\mathrm{R} \$ 5.990,00$.

O orçamento para as contratações foi desenvolvido baseado no SINAPI (Sistema Nacional de Pesquisa de Custos e Índices da Construção Civil) de dezembro de 2005 e na TCPO (Tabela de Composição de Preços e Orçamentos) ${ }^{89}$. Alguns serviços tiveram seus valores dados por levantamentos feitos pela EMR, segundo a normativa do INCRA que estabelece três orçamentos, e outros, ainda, por composição de valores dessas diversas fontes.

A planilha orçamentária prevê uma porcentagem de mão de obra mutirante, de acordo com o serviço a ser contratado, seguindo a premissa da modalidade Operações Coletiva. Se o serviço é muito especializado, por exemplo, assentamento de piso ou execução de madeiramento para telhado, a porcentagem de mão de obra mutirante é baixa, o que resulta em maior verba para contratação de mão de obra especializada. Caso este valor não fosse utilizado pelo beneficiário, ou seja, se o trabalho mutirante fosse total, o valor poderia ser revertido em material de construção na última etapa de obra. Para a Assistência Técnica, foi garantido um valor de até $4,5 \%$ referente ao custo total da obra por contrato individual.

Os orçamentos de reforma resultam em contratações de valores específicos para cada moradia, de acordo com os serviços previstos a serem executados. Assim, há uma enorme variação nos valores de mão de obra, de assistência técnica e de materiais de construção, ou seja, no valor total das obras de reforma contratadas. Para as casas novas, a variação nos valores se dá por conta das cinco diferentes tipologias desenvolvidas pela EMR que as famílias tinham a possibilidade de escolher para construir.

${ }^{89}$ A TCPO é publicada pela Editora PINI anualmente, desde 1955, e é muito utilizada como referência orçamentária no Brasil. 
Dentro do orçamento, a fossa séptica era obrigatória, e havia um projeto específico desenvolvido pela EMR para tal. A fossa séptica também era uma questão crucial na visão do então Superintendente do INCRA.

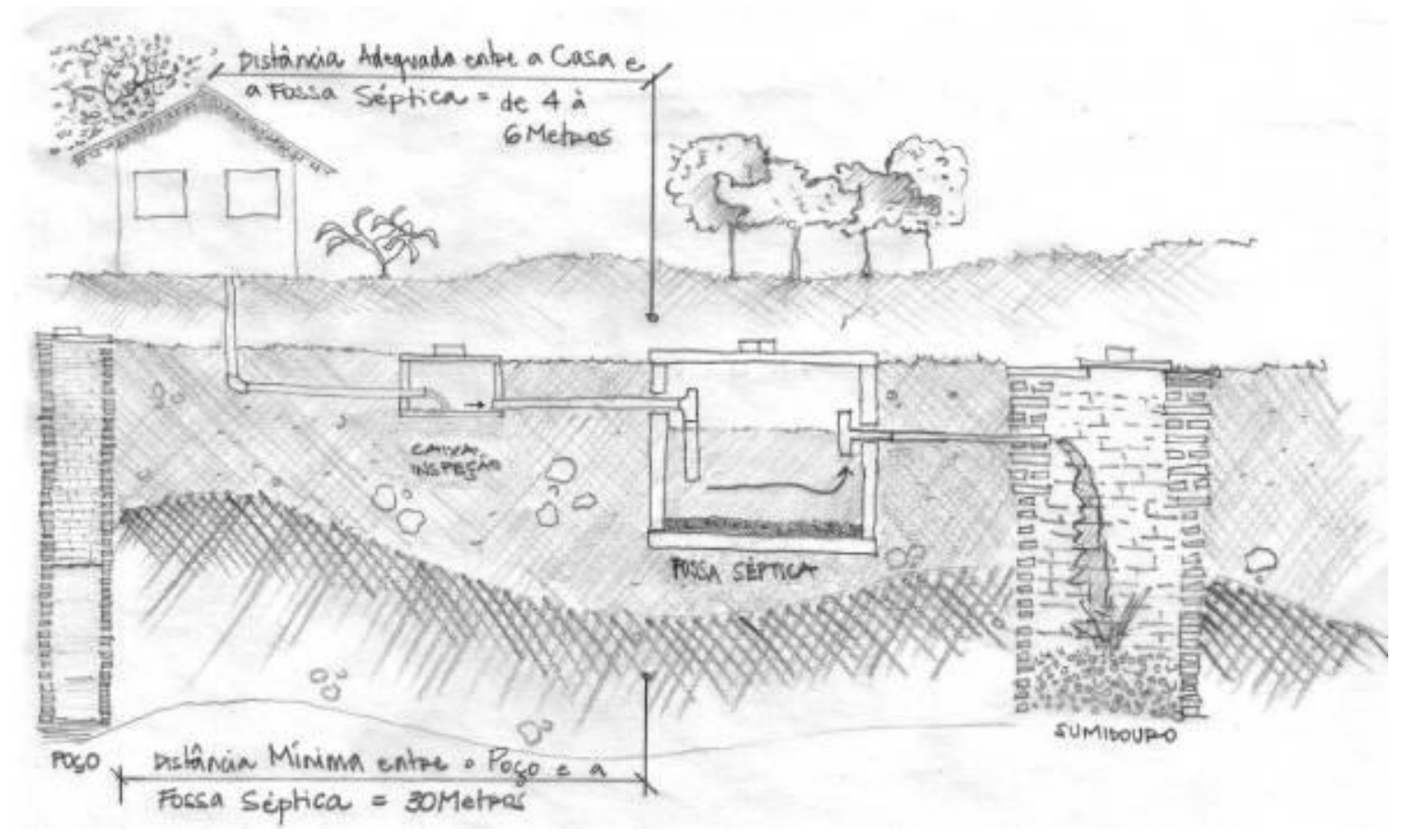

Figura 2 - Fossa Séptica padrão INCRA/SP.

Fonte: Equipe de Moradia Rural, jul. 2008.

Para as casas novas, a EMR formulou cinco tipologias padrão com média de 50 $\mathrm{m}^{2}$, com: dois quartos, sala, cozinha, banheiro e área de serviço, num orçamento de $\mathrm{R} \$ 10.990,00$ (Imagem 3).

As tipologias previam o que foi chamado de habitabilidade mínima pela Caixa: pé direito $\mathrm{h}=2,10 \mathrm{~m}$, acabamento mínimo nas áreas molhadas (azulejo no Box do banheiro $\mathrm{h}=1,80 \mathrm{~m}$, duas fiadas de azulejo sobre o lavatório, pia da cozinha e tanque), instalações elétricas e hidráulicas completas (com aparelhos), reboco externo em toda a moradia, piso cerâmico no banheiro, telhado de madeira com telhas cerâmicas, contrapiso desempenado no restante da moradia, esquadrias de madeira (portas) e metálicas (janelas) com vidros e a fossa séptica. 
Cada uma das tipologias priorizava um ambiente da residência, por exemplo, a tipo 1 apresenta quartos maiores, na tipo 2 a cozinha é maior, na tipo 3 há uma varanda contemplada, a tipo 4 tem a sala de maior dimensão, e na tipo 5 o banheiro é maior.

As tipologias 1 e 5 foram adaptadas para os casos que contavam com o valor do recurso do INCRA a aplicar, e ainda contavam com o maior valor de subsídio. Assim, o valor total da obra era de R\$16.990,00 (R\$ 5 mil do INCRA + R\$ 11.990,00 de subsídio para municípios da RMSP $=\mathrm{R} \$ 16.990,00)$. O projeto dessas tipologias especiais apresentava três quartos e varanda frontal.

Para os casos de valor de subsídio de $\mathrm{R} \$$ 8.990,00 (municípios com mais de 100 mil habitantes) e ainda o recurso do INCRA a aplicar, ou seja, com o valor total da obra: $\mathrm{R} \$ 13.990,00$, as mesmas tipologias foram adaptadas para três quartos sem a varanda.

Para os casos de beneficiários que já tinham aplicado o PRA (R\$3.000,00), mas cujas casas não tinham condição de habitação, como casas de madeira, as tipologias 1 e 4 foram adaptadas, com os acabamentos já descritos, porém com apenas um quarto.

Assim, os orçamentos de casas novas contavam com as cinco tipologias padrão, e ainda três adaptações. Todos os projetos previam grande participação mutirante, principalmente para redução dos custos com mão de obra, além de terem sido desenvolvidas para facilitar futuras ampliações com recursos próprios dos beneficiários. 


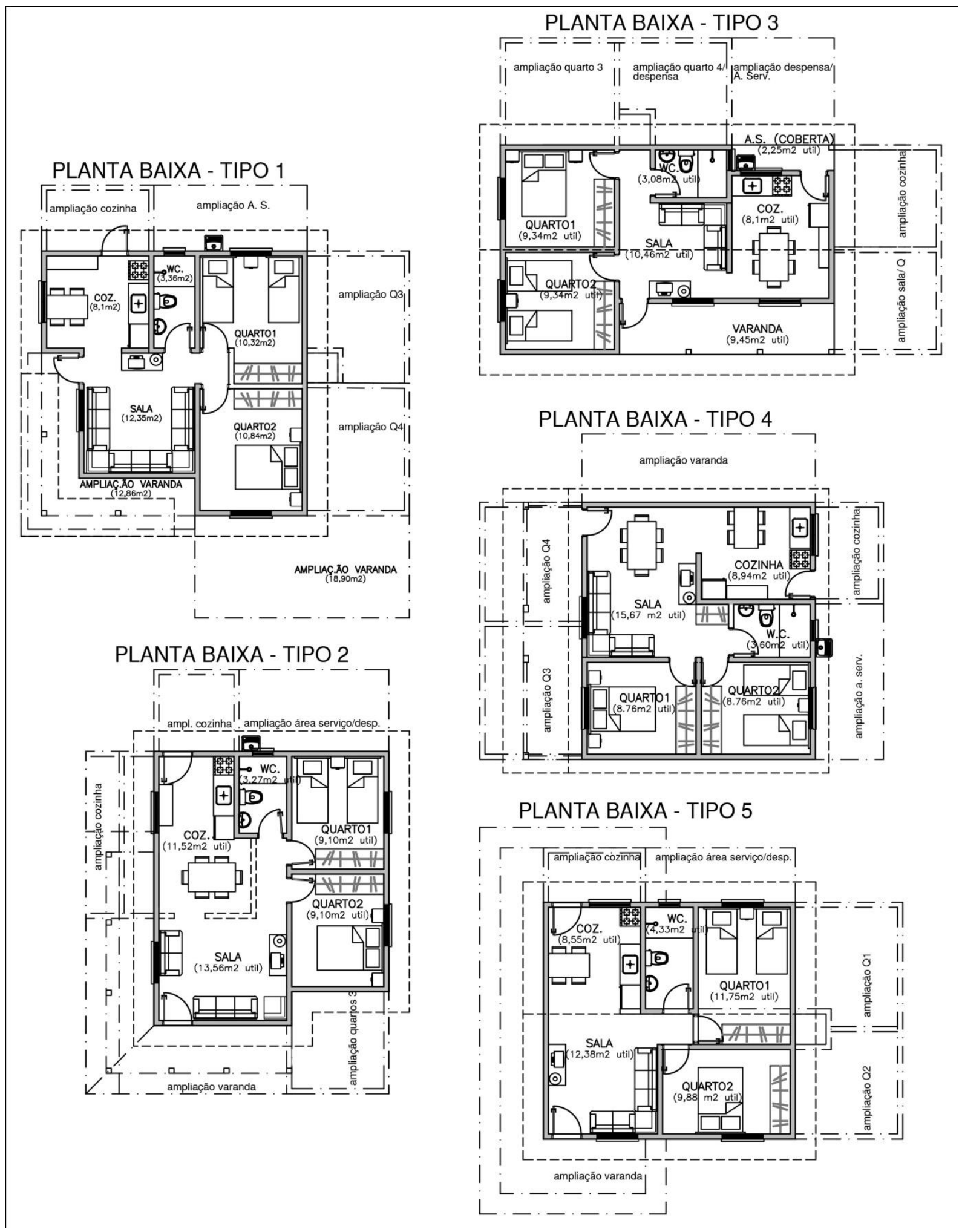

Figura 3 - TIPOLOGIAS PADRÃO: 2 quartos, valor da obra R\$ 10.990,00.

Fonte: Equipe de Moradia Rural, sem escala, dez. 2006, adaptado para o presente trabalho. 
No início das contratações, o panorama do estado de São Paulo, em 2006, era de aproximadamente 4.375 famílias distribuídas em 60 PA a pleitearem o financiamento junto à Caixa. Ao final, 1.021 casas novas e 2.047 reformas foram contratadas num total de 3.068 intervenções (Mapa 2, Tabela 11), o que representa aproximadamente $70 \%$ da demanda inicial, e distribuídas em 57 assentamentos (95\% dos demandantes) no estado de São Paulo. O período de contratação foi estipulado pela Caixa para que terminasse em abril de 2007, e o INCRA/SP priorizou a contratação dos assentamentos federais criados até $2005^{90}$.

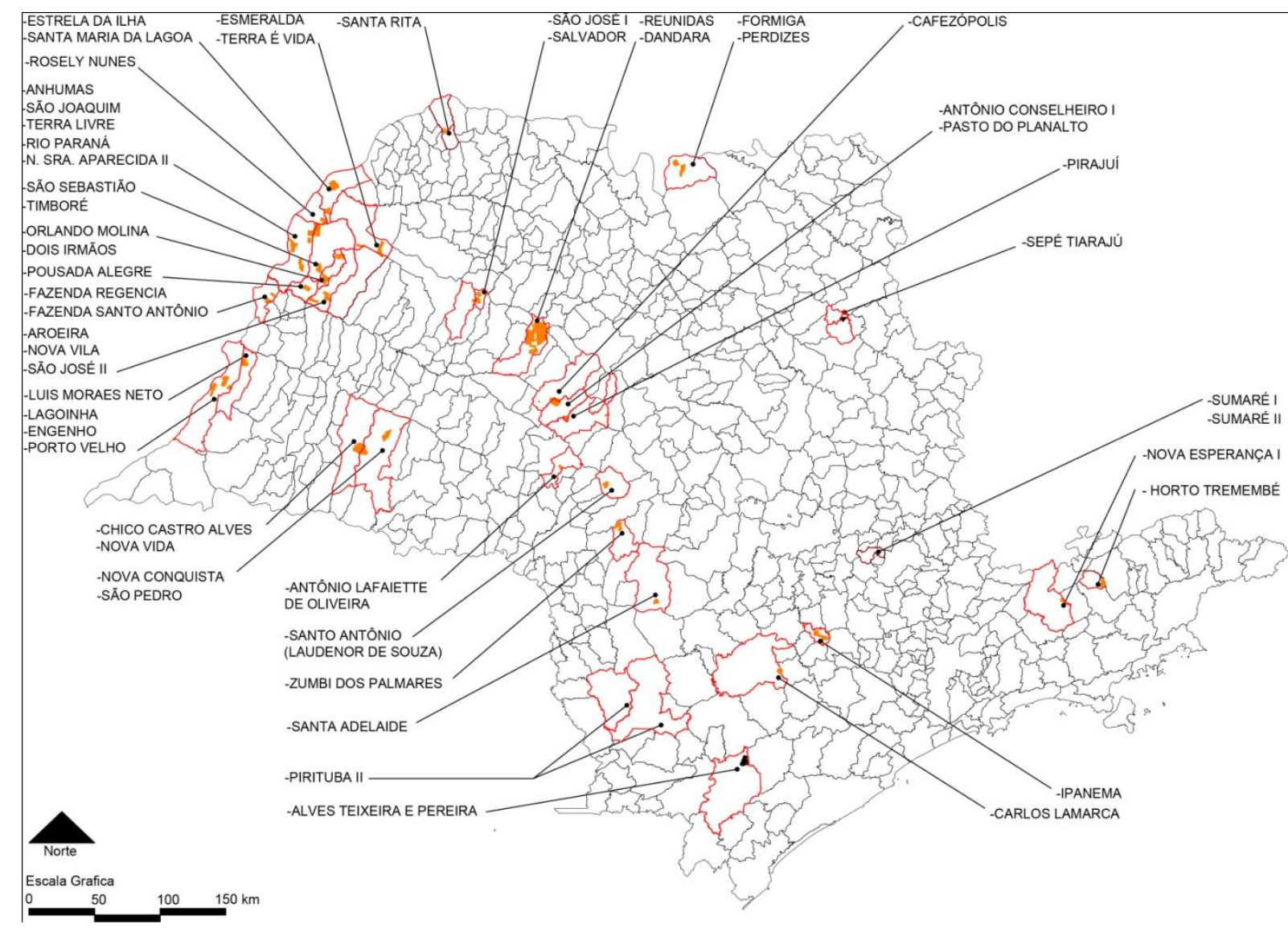

Mapa 2 - Contratações Moradia Rural INCRA/SP. trabalho.

Fonte: Equipe de Moradia Rural, 2007, sem escala, adaptado para o presente

${ }^{90}$ As contratações incluíram os assentamentos estaduais: PE Pirituba - áreas I a VI, no município de Itapeva/ Itaberá - SP e PE Sumaré I e II, no município de Sumaré - SP, num total de 427 famílias. Esses PE entraram para as contratações por razões políticas: o grupo de Sumaré é um dos fundadores do MST no estado de SP, e o grupo da Pirituba tinha relações pessoais com o Superintendente do INCRA/SP da época. 
Tabela 11 - Contratações e valores Programa Moradia Rural INCRA/SP91 ( (continua).

\begin{tabular}{|c|c|c|c|c|c|c|c|}
\hline \multicolumn{8}{|c|}{ Regional Bauru } \\
\hline Nome do PA & Município & Ass. & $\mathrm{C}$ & $\mathbf{R}$ & $\begin{array}{l}\text { RECURSOS } \\
\text { FGTS }\end{array}$ & $\begin{array}{l}\text { RECURSOS } \\
\text { INCRA/SP }\end{array}$ & $\begin{array}{c}\text { VALOR } \\
\text { TOTAL DE } \\
\text { OBRA }\end{array}$ \\
\hline $\begin{array}{l}\text { Antônio } \\
\text { Conselheiro }\end{array}$ & Guarantã & 87 & 0 & 87 & $\mathrm{R} \$ 520.799,91$ & $\mathrm{R} \$ 3$ mil A. & $\mathrm{R} \$ 781.799,91$ \\
\hline $\begin{array}{l}\text { Antônio } \\
\text { Lafaiete de } \\
\text { Oliveira }\end{array}$ & Gália & 13 & 13 & 0 & $\mathrm{R} \$ 77.835,21$ & $\mathrm{R} \$ 65.000$ & $\mathrm{R} \$ 142.835,21$ \\
\hline Cafezópolis & Cafelândia & 3 & 3 & 0 & $\mathrm{R} \$ 17.969,82$ & $\mathrm{R} \$ 3$ mil A. & $\mathrm{R} \$ 26.969,82$ \\
\hline Dandara & Promissão & 179 & 179 & 0 & $\mathrm{R} \$ 1.072 .023,77$ & $\mathrm{R} \$ 5 \mathrm{mil} \mathrm{A}$. & $\mathrm{R} \$ 1.967 .023,77$ \\
\hline $\begin{array}{l}\text { Pasto do } \\
\text { Planalto }\end{array}$ & Guarantã & 23 & 0 & 23 & $\mathrm{R} \$ 137.736,61$ & R\$ 3 mil A. & $\mathrm{R} \$ 206.736,61$ \\
\hline Pirajuí & Piraju & 4 & 0 & 4 & $\mathrm{R} \$ 23.961,52$ & $\mathrm{R} \$ 3$ mil A. & $\mathrm{R} \$ 35.961,52$ \\
\hline Reunidas & Promissão & 360 & 14 & 346 & $\mathrm{R} \$ 2.035 .396,65$ & $\mathrm{R} \$ 3$ mil A. & $\mathrm{R} \$ 3.115 .396,65$ \\
\hline Sta. Adelaide & Avaré & 19 & 3 & 16 & $\mathrm{R} \$ 108.729,87$ & $\mathrm{R} \$ 15.000$ & $\mathrm{R} \$ 171.729,87$ \\
\hline $\begin{array}{l}\text { Sto. Antônio } \\
\text { (Laudenor } \\
\text { de Souza) }\end{array}$ & Piratininga & 20 & 2 & 18 & $\mathrm{R} \$ 119.118,39$ & $\begin{array}{l}\text { R\$ } 3 \text { mil A. R; } \\
\text { R\$ } 5 \text { mil C. }\end{array}$ & $\mathrm{R} \$ 183.118,39$ \\
\hline $\begin{array}{l}\text { Zumbi dos } \\
\text { Palmares }\end{array}$ & Iaras & 192 & 152 & 40 & $\mathrm{R} \$ 1.240 .385,00$ & $\mathrm{R} \$ 760.000$ & $\mathrm{R} \$ 2.120 .385,00$ \\
\hline $10 \mathrm{PA}$ & TOTAL & 900 & 366 & 534 & $\mathrm{R} \$ 5.353 .956,75$ & $\mathrm{R} \$ \mathbf{8 4 0 . 0 0 0 , 0 0}$ & $\mathrm{R} \$ 8.751 .956,75$ \\
\hline \multicolumn{8}{|c|}{ Regional Campinas } \\
\hline Sumaré I & Sumaré & 22 & 0 & 22 & $\mathrm{R} \$ 197.672,21$ & $\mathrm{R} \$ 3$ mil A. & $\mathrm{R} \$ 263.672,21$ \\
\hline Sumaré II & Sumaré & 29 & 0 & 29 & $\mathrm{R} \$ 250.016,23$ & $\mathrm{R} \$ 3$ mil A. & $\mathrm{R} \$ 363.016,23$ \\
\hline $2 \mathrm{PA}$ & TOTAL & 51 & 0 & 51 & $\mathrm{R} \$ 447.688,44$ & $\mathrm{R} \$ 0,00$ & $\mathrm{R} \$ 626.688,44$ \\
\hline \multicolumn{8}{|c|}{ Regional Ribeirão Preto } \\
\hline Sepé Tiaraju & Serrana & 77 & 77 & 0 & $\mathrm{R} \$ 682.165,00$ & $\mathrm{R} \$ 385.000$ & $\mathrm{R} \$ 1.067 .165,00$ \\
\hline $1 \mathrm{PA}$ & TOTAL & 77 & 77 & 0 & $\mathrm{R} \$ \mathbf{6 8 2 . 1 6 5 , 0 0}$ & $\mathrm{R} \$ 385.000,00$ & $\mathrm{R} \$ 1.067 .165,00$ \\
\hline \multicolumn{8}{|c|}{ Regional Santos } \\
\hline $\begin{array}{c}\text { Alves, } \\
\text { Teixeira e } \\
\text { Pereira }\end{array}$ & Eldorado & 67 & 67 & 0 & $\mathrm{R} \$ 401.199,72$ & $\mathrm{R} \$ 335.000$ & $\mathrm{R} \$ 736.199,72$ \\
\hline $1 \mathrm{PA}$ & TOTAL & 67 & 67 & 0 & $\mathrm{R} \$ 401.199,72$ & $\mathrm{R} \$ 335.000,00$ & $\mathrm{R} \$ \mathbf{7 3 6 . 1 9 9 , 7 2}$ \\
\hline \multicolumn{8}{|c|}{ Regional São José dos Campos } \\
\hline $\begin{array}{l}\text { Horto } \\
\text { Tremembé }\end{array}$ & Tremembé & 85 & 6 & 79 & $\mathrm{R} \$ 758.719,95$ & $\mathrm{R} \$ 8.000$ & $\mathrm{R} \$ 1.025 .719,95$ \\
\hline $\begin{array}{c}\text { Nova } \\
\text { Esperança I }\end{array}$ & $\begin{array}{c}\text { São José dos } \\
\text { Campos }\end{array}$ & 24 & 0 & 24 & $\mathrm{R} \$ 213.480,00$ & $\mathrm{R} \$ 3$ mil A. & $\mathrm{R} \$ 285.480,00$ \\
\hline $2 \mathrm{PA}$ & TOTAL & 109 & 6 & 103 & R\$ 972.199,95 & $\mathrm{R} \$ 8.000,00$ & R\$ 1.311.199,95 \\
\hline
\end{tabular}

91 As regionais relacionadas na Tabela são de acordo com suas Superintendências Regionais da Caixa no estado de São Paulo, referência ano 2007. 
Tabela 11 - Contratações e valores Programa Moradia Rural INCRA/SP (continuação).

\begin{tabular}{|c|c|c|c|c|c|c|c|}
\hline Nome do PA & Município & Ass. & $\mathrm{C}$ & $\mathbf{R}$ & $\begin{array}{l}\text { RECURSOS } \\
\text { FGTS }\end{array}$ & $\begin{array}{l}\text { RECURSOS } \\
\text { INCRA/SP }\end{array}$ & $\begin{array}{c}\text { VALOR } \\
\text { TOTAL DE } \\
\text { OBRA } \\
\end{array}$ \\
\hline \multicolumn{8}{|c|}{ Regional Presidente Prudente } \\
\hline Anhumas & Castilho & 33 & 0 & 33 & $\mathrm{R} \$ 197.491,43$ & $\mathrm{R} \$ 3$ mil A. & $\mathrm{R} \$ 296.491,43$ \\
\hline Aroeira & Guaraçaí & 9 & 0 & 9 & $\mathrm{R} \$ 53.885,31$ & $\mathrm{R} \$ 3$ mil A. & $\mathrm{R} \$ 80.885,31$ \\
\hline Dois Irmãos & $\begin{array}{l}\text { Murutinga do } \\
\text { Sul }\end{array}$ & 61 & 61 & 0 & $\mathrm{R} \$ 359.223,00$ & $\mathrm{R} \$ 5 \mathrm{mil}$ A. & $\mathrm{R} \$ 664.223,00$ \\
\hline $\begin{array}{c}\text { Nossa } \\
\text { Senhora } \\
\text { Aparecida II }\end{array}$ & Castilho & 47 & 24 & 23 & $\mathrm{R} \$ 280.460,70$ & $\begin{array}{l}\mathrm{R} \$ 3 \text { mil A. } \\
\quad \mathrm{Re} \mathrm{C}\end{array}$ & $\mathrm{R} \$ 421.460,70$ \\
\hline Nova Vila & Guaraçaí & 34 & 0 & 34 & $\mathrm{R} \$ 203.560,67$ & $\mathrm{R} \$ 3$ mil A. & $\mathrm{R} \$ 305.560,67$ \\
\hline $\begin{array}{l}\text { Orlando } \\
\text { Molina }\end{array}$ & $\begin{array}{l}\text { Murutinga do } \\
\text { Sul }\end{array}$ & 39 & 0 & 39 & $\mathrm{R} \$ 233.252,20$ & $\mathrm{R} \$ 3$ mil A. & $\mathrm{R} \$ 350.252,20$ \\
\hline $\begin{array}{l}\text { Pousada } \\
\text { Alegre }\end{array}$ & N.Independência & 39 & 39 & 0 & $\mathrm{R} \$ 233.517,00$ & $\mathrm{R} \$ 5 \mathrm{mil}$ A. & $\mathrm{R} \$ 428.517,00$ \\
\hline Rio Paraná & Castilho & 28 & 0 & 28 & $\mathrm{R} \$ 167.462,62$ & $\mathrm{R} \$ 3$ mil A. & $\mathrm{R} \$ 251.462,62$ \\
\hline Salvador & Brejo Alegre & 10 & 0 & 10 & $\mathrm{R} \$ 59.791,95$ & $\mathrm{R} \$ 3$ mil A. & $\mathrm{R} \$ 89.791,95$ \\
\hline São Joaquim & Castilho & 27 & 0 & 27 & $\mathrm{R} \$ 161.571,00$ & R\$ 3 mil A. & $\mathrm{R} \$ 242.571,00$ \\
\hline São Jose I & $\begin{array}{l}\text { Birigui/ Brejo } \\
\text { Alegre }\end{array}$ & 29 & 0 & 29 & $\mathrm{R} \$ 173.486,85$ & R\$ 3 mil A. & $\mathrm{R} \$ 260.486,85$ \\
\hline São José II & Guaraçaí & 18 & 0 & 18 & $\mathrm{R} \$ 107.507,17$ & $\mathrm{R} \$ 3$ mil A. & $\mathrm{R} \$ 161.507,17$ \\
\hline $\begin{array}{c}\text { São } \\
\text { Sebastião }\end{array}$ & Andradina & 51 & 0 & 51 & $\mathrm{R} \$ 305.367,39$ & $\mathrm{R} \$ 3$ mil A. & $\mathrm{R} \$ 458.367,39$ \\
\hline $\begin{array}{l}\text { Rosely } \\
\text { Nunes }\end{array}$ & Itapura & 52 & 49 & 3 & $\mathrm{R} \$ 311.342,04$ & $\mathrm{R} \$ 5 \mathrm{mil} \mathrm{A}$. & $\mathrm{R} \$ 571.342,04$ \\
\hline Terra Livre & Castilho & 27 & 0 & 27 & $\mathrm{R} \$ 161.450,00$ & $\mathrm{R} \$ 3$ mil A. & $\mathrm{R} \$ 242.450,00$ \\
\hline Timboré & Andradina & 92 & 15 & 77 & $\mathrm{R} \$ 542.004,85$ & $\mathrm{R} \$ 3$ mil A. & $\mathrm{R} \$ 818.004,85$ \\
\hline $\begin{array}{c}\text { Chico Castro } \\
\text { Alves }\end{array}$ & Martinópolis & 65 & 0 & 65 & $\mathrm{R} \$ 388.574,89$ & $\mathrm{R} \$ 3$ mil A. & $\mathrm{R} \$ 583.574,89$ \\
\hline $\begin{array}{l}\text { Nova } \\
\text { Conquista }\end{array}$ & Rancharia & 74 & 0 & 74 & $\mathrm{R} \$ 443.547,16$ & $\mathrm{R} \$ 3$ mil A. & $\mathrm{R} \$ 665.547,16$ \\
\hline Nova Vida & Martinópolis & 27 & 0 & 27 & $\mathrm{R} \$ 161.444,77$ & $\mathrm{R} \$ 3$ mil A. & $\mathrm{R} \$ 242.444,77$ \\
\hline São Pedro & Rancharia & 15 & 0 & 15 & $\mathrm{R} \$ 89.227,71$ & $\mathrm{R} \$ 3$ mil A. & $\mathrm{R} \$ 134.227,71$ \\
\hline Engenho & $\begin{array}{l}\text { Caiuá/Presid. } \\
\text { Epitácio }\end{array}$ & 6 & 0 & 6 & $\mathrm{R} \$ 35.915,00$ & $\mathrm{R} \$ 3$ mil A. & $\mathrm{R} \$ 53.915,00$ \\
\hline Lagoinha & Presid. Epitácio & 107 & 0 & 107 & $\mathrm{R} \$ 640.435,47$ & $\mathrm{R} \$ 3$ mil A. & $\mathrm{R} \$ 961.435,47$ \\
\hline $\begin{array}{l}\text { Luis Moraes } \\
\text { Neto }\end{array}$ & Caiuá & 84 & 0 & 84 & $\mathrm{R} \$ 502.966,11$ & R\$ 3 mil A. & $\mathrm{R} \$ 754.966,11$ \\
\hline Porto Velho & Presid. Epitácio & 16 & 0 & 16 & $\mathrm{R} \$ 95.782,65$ & $\mathrm{R} \$ 3$ mil A. & $\mathrm{R} \$ 143.782,65$ \\
\hline Regência & Paulicéia & 23 & 0 & 23 & $\mathrm{R} \$ 137.735,00$ & $\mathrm{R} \$ 3$ mil A. & $\mathrm{R} \$ 206.735,00$ \\
\hline Sto. Antonio & Paulicéia & 26 & 0 & 26 & $\mathrm{R} \$ 155.716,00$ & $\mathrm{R} \$ 3$ mil A. & $\mathrm{R} \$ 233.716,00$ \\
\hline $26 \mathrm{PA}$ & TOTAL & 1039 & 188 & 851 & $R \$ 6.202 .718,94$ & $R \$ 0,00$ & $\mathrm{R} \$ 9.623 .718,94$ \\
\hline
\end{tabular}


Tabela 11 - Contratações e valores Programa Moradia Rural INCRA/SP (conclusão).

\begin{tabular}{|c|c|c|c|c|c|c|c|}
\hline $\begin{array}{l}\text { Numero de } \\
\text { PA }\end{array}$ & & Ass. & C & $\mathbf{R}$ & $\begin{array}{l}\text { RECURSOS } \\
\text { FGTS }\end{array}$ & $\begin{array}{l}\text { RECURSOS } \\
\text { INCRA/SP }\end{array}$ & $\begin{array}{l}\text { VALOR } \\
\text { TOTAL DE } \\
\text { OBRA }\end{array}$ \\
\hline \multicolumn{8}{|c|}{ Regional São José do Rio Preto } \\
\hline Esmeralda & Pereira Barreto & 71 & 2 & 69 & $\mathrm{R} \$ 425.126,41$ & $\mathrm{R} \$ 3$ mil A. & $\mathrm{R} \$ 638.126,71$ \\
\hline $\begin{array}{l}\text { Estrela da } \\
\text { Ilha }\end{array}$ & Ilha Solteira & 186 & 186 & 0 & $\mathrm{R} \$ 1.113 .634,08$ & $\mathrm{R} \$ 5$ mil A. & $\mathrm{R} \$ 2.043 .634,08$ \\
\hline Formiga & Colômbia & 44 & 0 & 44 & $\mathrm{R} \$ 263.371,15$ & $\mathrm{R} \$ 3$ mil A. & $\mathrm{R} \$ 395.371,15$ \\
\hline Perdizes & Colômbia & 10 & 0 & 10 & $\mathrm{R} \$ 59.889,04$ & $\mathrm{R} \$ 3$ mil A. & $\mathrm{R} \$ 89.889,04$ \\
\hline $\begin{array}{l}\text { Santa Maria } \\
\text { da Lagoa }\end{array}$ & Ilha Solteira & 61 & 1 & 60 & $\mathrm{R} \$ 419.013,36$ & $\begin{array}{c}\text { R\$ 5mil em } 41 \\
\text { UH; R\$ } 3 \text { mil } \\
\text { em } 20 \text { UH. }\end{array}$ & $\mathrm{R} \$ 684.013,36$ \\
\hline Santa Rita & Turmalina & 17 & 4 & 13 & $\mathrm{R} \$ 101.755,00$ & $\mathrm{R} \$ 3$ mil A. & $\mathrm{R} \$ 152.755,00$ \\
\hline Terra é Vida & Pereira Barreto & 32 & 0 & 32 & $\mathrm{R} \$ 191.636,29$ & $\mathrm{R} \$ 3$ mil A. & $\mathrm{R} \$ 287.636,29$ \\
\hline $7 \mathrm{PA}$ & TOTAL & 421 & 193 & 228 & $\mathrm{R} \$ 2.574 .425,33$ & $\mathrm{R} \$ 0,00$ & $\mathrm{R} \$ 4.291 .425,63$ \\
\hline \multicolumn{8}{|c|}{ Regional Sorocaba } \\
\hline $\begin{array}{l}\text { Carlos } \\
\text { Lamarca }\end{array}$ & Itapetininga & 39 & 0 & 39 & $\mathrm{R} \$ 350.356,64$ & $\mathrm{R} \$ 3$ mil A. & $\mathrm{R} \$ 467.356,64$ \\
\hline Ipanema & Iperó & 120 & 26 & 94 & $\mathrm{R} \$ 1.078 .346,58$ & $\mathrm{R} \$ 3$ mil A. & $\mathrm{R} \$ 1.438 .346,58$ \\
\hline $\begin{array}{l}\text { Pirituba II } \\
\text { Área I }\end{array}$ & Itapeva & 59 & 28 & 31 & $\mathrm{R} \$ 353.169,00$ & $\mathrm{R} \$ 177.000$ & $\mathrm{R} \$ 530.169,00$ \\
\hline $\begin{array}{l}\text { Pirituba II } \\
\text { Área II }\end{array}$ & Itapeva & 50 & 12 & 38 & $\mathrm{R} \$ 298.728,00$ & $\mathrm{R} \$ 150.000$ & $\mathrm{R} \$ 448.728,00$ \\
\hline $\begin{array}{l}\text { Pirituba II } \\
\text { Área III }\end{array}$ & Itaberá & 34 & 9 & 25 & $\mathrm{R} \$ 203.509,81$ & $\mathrm{R} \$ 102.000$ & $\mathrm{R} \$ 305.509,81$ \\
\hline $\begin{array}{l}\text { Pirituba II } \\
\text { Área IV }\end{array}$ & Itapeva & 36 & 11 & 25 & $\mathrm{R} \$ 209.555,71$ & $\mathrm{R} \$ 108.000$ & $\mathrm{R} \$ 317.555,71$ \\
\hline $\begin{array}{c}\text { Pirituba II } \\
\text { Área V }\end{array}$ & Itaberá & 38 & 11 & 27 & $\mathrm{R} \$ 227.442,00$ & $\mathrm{R} \$ 114.000$ & $\mathrm{R} \$ 341.442,00$ \\
\hline $\begin{array}{l}\text { Pirituba II } \\
\text { Área VI }\end{array}$ & Itaberá & 28 & 27 & 1 & $\mathrm{R} \$ 173.520,00$ & $\mathrm{R} \$ 84.000$ & $\mathrm{R} \$ 257.520,00$ \\
\hline $8 \mathrm{PA}$ & TOTAL & 404 & 124 & 280 & $\mathrm{R} \$ 2.894 .627,74$ & $R \$ 735.000,00$ & $\mathrm{R} \$ 4.106 .627,74$ \\
\hline 57 PA & $\begin{array}{c}\text { TOTAL } \\
\text { CONTRATADO } \\
\text { NO ESTADO }\end{array}$ & 3068 & 1021 & 2047 & $\begin{array}{c}\mathrm{R} \$ \\
19.528 .981,87\end{array}$ & $\begin{array}{c}\mathrm{R} \$ \\
2.303 .000,00\end{array}$ & $\begin{array}{c}\mathrm{R} \$ \\
30.514 .982,17\end{array}$ \\
\hline
\end{tabular}

\section{Observações:}

*Ass.: Contratos assinados;

${ }^{*} \mathrm{C}$ : Construção

* A.: aplicado

${ }^{*}$ R: Reforma

Fonte: Equipe de Moradia Rural, abr. 2007. 
A possibilidade de novas contratações após o encerramento estabelecido pela Caixa em 2007 ficou em aberto, e em 2008 a Caixa sinalizava que poderia restabelecer o Acordo Caixa X INCRA/SP, mas a partir de 2009 a Caixa contratou empreendimentos no mundo rural somente via Programa Minha Casa, Minha Vida Rural.

Para as contratações, foram realizadas diversas vistorias pela EMR, para levantar, principalmente a situação das reformas, já que para as casas novas, foram realizadas assembleias para a escolha das tipologias a serem executadas por cada família. A maioria das reformas necessitava urgentemente de intervenções diante da precariedade de suas construções e das instalações elétricas e hidráulicas, quando estas existiam, além de nenhuma das casas possuírem uma solução de tratamento sanitário mais adequado que uma fossa negra.

Para essas vistorias foi desenvolvido um check list de campo onde era levantado o tamanho, os materiais utilizados e as condições das moradias. A situação da aplicação dos recursos do PRA também era parte do levantamento. Por fim, a Equipe anotava os desejos de reforma ou ampliações das famílias.

Os orçamentos para as reformas levaram em consideração aquelas questões de habitabilidade mínima, e principalmente a execução de fossa séptica. Para a questão dos telhados, foi acordado com a Caixa que no caso de cobertura com telhas do tipo fibrocimento, seria obrigatória a instalação de forro, sendo que nos casos de cobertura com telha de barro, o forro não era obrigatório.

Após meses de vistorias e processamento de informações, iniciou-se de fato a contratação. Foi enviado à Caixa o cadastro dos beneficiários apresentados pela EO, do qual constavam os dados cadastrais e de renda das famílias - titular e cônjuge, e também as cópias dos documentos ${ }^{92}$.

92 Para o estado civil dos beneficiários foi elaborada uma declaração assinada pelo Superintendente do INCRA/SP, já que inúmeros assentados não possuíam esse tipo de documentação. Normalmente, essas declarações eram de união estável ou LINS (local incerto e não sabido) - para os casos dos que possuíam certidão de casamento sem averbação de divórcio, ou seja, o cônjuge era declarado "sumido" ou em local incerto e não sabido. 
A documentação dos beneficiários passou por uma análise cadastral na Caixa, pois a normativa do programa previa algumas exclusões: ter dívida ativa referente à tributos federais, ter CADMUT ativo ${ }^{93}$, ter benefícios ativos do Instituto Nacional de Seguridade Social (INSS) - o que aumentaria a renda acima daquela faixa prevista para o maior valor de subsídio ${ }^{94}$, e ainda ter idade superior à setenta e cinco anos. É por essa razão que não foi possível a contratação de todos os beneficiários dos assentamentos pleiteados. Apenas um PA teve 100\% dos seus beneficiários contratados pelo programa, o PA Cafezópolis (município de Cafelândia) que contava com 3 beneficiários que foram todos contratados no Programa.

Essa questão dos "idosos" - idade superior a 75 anos - gerou bastante questionamento, e merece maior atenção. Isso porque o sistema da Caixa entende que o indivíduo com mais de 75 anos na época da contratação - 2006 - não teria tempo de vida suficiente para pagar a garantia caução que essa modalidade de financiamento prevê para qualquer outra Entidade Organizadora. Porém, as contratações com o INCRA/SP foram a "fundo perdido", ou seja, sem pagamento de caução - até por que em muitos casos a caução já estava aplicada na obra. Assim, 41 "idosos" deixaram de assinar contrato com a Caixa no estado de São Paulo.

1307 assentados deixaram de assinar contrato com a Caixa por essas e outras razões, como: problemas com cadastro (CADMUT, renda ou idade superior), irregularidades com o INCRA, processos que não foram contratados por não terem sido analisados a tempo pela Caixa, ou por terem sido reapresentados fora do prazo de contratação, processos perdidos na Caixa, mas enviados pelo INCRA/SP, e ainda processos de beneficiários desistentes da contratação.

Para a contratação, era necessário elaborar o cronograma de obra, ou cronograma de desembolso, que foi estipulado em quatro etapas, e não em meses,

93 CADMUT: cadastro nacional de mutuários. CADMUT ativo significa que o individuo já foi beneficiário de algum outro programa federal, estadual ou municipal para financiamento de habitação com recursos do FGTS. Este cadastro tem a intenção de não permitir que uma mesma pessoa acesse mais de uma vez este tipo de recurso.

${ }^{94}$ Não seria possível a contratação para renda superior, como foi chamado, por que aumentaria também o valor da caução. 
como é de costume nas contratações urbanas da Caixa. Isso porque não seria possível um controle mensal de desembolso nem de execução de obra, por uma série de razões.

Para cada liberação de recurso, a EMR deveria produzir peças técnicas de cada empreendimento contratado a partir de vistorias realizadas nas obras - as medições. As vistorias tinham o intuito de verificar a aplicação dos materiais de construção adquiridos por cada beneficiário, identificar eventuais problemas de obra e ainda irregularidades com o INCRA.

Para a medição ser aprovada pela Caixa, cada beneficiário do empreendimento deve atingir a porcentagem de execução de obra (física) igual ou maior que a porcentagem de recurso (dinheiro) liberado. Mas, se alguns beneficiários gastam recursos mas não constroem, e o grupo não atinge a porcentagem de execução de obra maior ou igual a de recursos gastos, todos no grupo ficam bloqueados. Há os casos de beneficiários que não atingem a tal porcentagem, mas a média do grupo atinge, assim, o grupo pode ser liberado para a próxima etapa de obra. Esse é o sistema de contratação individual, mas de operação coletiva.

As contratações se deram em grupos de no máximo 50 unidades $\mathrm{UH}^{95}$ que formavam um empreendimento, divididos em casas novas e reformas. Quase na totalidade das contratações, um mesmo assentamento possuía mais de um empreendimento.

Infelizmente, por falta de tempo ou de atenção da EMR, as contratações seguiram a ordem alfabética das RB de cada assentamento, o que causou grandes problemas na execução da obra. Isso ocorreu porque a contratação é individual, mas a operação é coletiva, assim, todos os beneficiários do empreendimento estão vinculados. E como a ideia do orçamento era utilizar a mão de obra mutirante, quanto mais perto cada beneficiário estivesse de seu companheiro de empreendimento, mais fácil seria a organização do mutirão.

95 Esta limitação era dada pela Caixa, para uma "melhor formatação" da planilha de contratação. Assim, 50 beneficiários, ou seja, 50 linhas, resultavam numa planilha de duas páginas. 
Antes do início da obra em si, era necessário fazer um orçamento real dos materiais de construção disponíveis nas proximidades de cada assentamento, pois as planilhas de contratação contavam com dados referentes a 2005, e as contratações foram finalizadas em abril de 2007. Os três procuradores de cada PA foram os responsáveis por esses orçamentos, e uma assembléia definiria onde seria comprado o material. Muitos materiais foram cotados e adquiridos fora das lojas convencionais, como areia orçada em portos de areia e tijolos em olarias.

Havia um problema em relação ao grande número de contratações em pequenos municípios, que contavam com poucas lojas de material de construção. Portanto, a dificuldade de entrega dos materiais nos PA era um problema, por causa das distâncias entre os PA e a cidade; dentro dos PA, entre uma casa e outra; e ainda pela precariedade das estradas internas ou que davam acesso aos PA.

Para o inicio das obras, a EMR desenvolveu uma lista de materiais a ser adquirida por cada beneficiário de acordo com os serviços de sua contratação. É importante dizer, que para o início das obras não foi comunicado aos beneficiários o que havia sido contratado - no caso das reformas. Tanto a Equipe quanto o Superintendente entendiam que esta informação se fazia necessária, porém ela não foi feita.

Como já esperado pela EMR, muitas alterações foram feitas nas listas de compras. Assim, para um melhor controle, foi desenvolvido um plano de obra (Imagem 4) em que apareciam, por escrito, todos os compromissos contratados com a Caixa em todas as etapas da obra. Esse era o resumo da contratação individual e salientava as questões de habitabilidade mínima. No plano foi inserida uma foto de cada casa para facilitar a identificação das mesmas na produção das peças técnicas. $\mathrm{O}$ plano também facilitava a compra nas lojas, pois cada lojista anotava no verso do plano o valor vendido ao beneficiário, com carimbo da loja, para evitar ultrapassar os limites de gastos estipulados por etapa. 

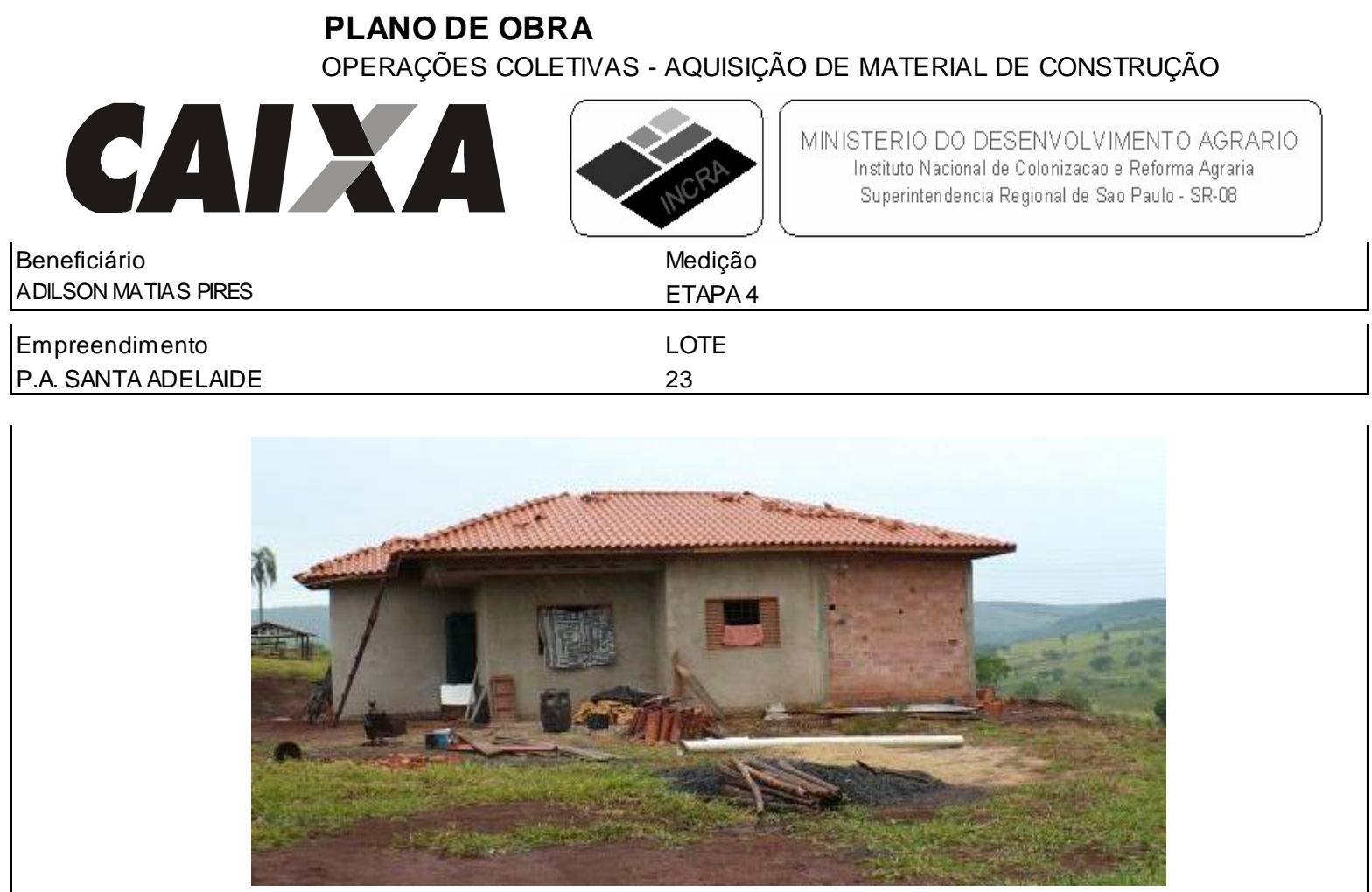

ASSENTAMENTO SANTA ADELAIDE - (IARAS)

VALOR TOTAL DE MATERIAL LIBERADO NAS ETAPAS 1, 2, 3 E 4 = $R \$ 4.676,08$

\begin{tabular}{|c|c|}
\hline VALOR LIBERADO PARA M.O NA ETAPA & $\mathrm{R} \$ 200,00$ \\
\hline VALOR LIBERADO PARA ASSIST. TÉCNICA NA ETAPA & $\mathrm{R} \$ 54,00$ \\
\hline VALOR GASTO EM MATERIAL NAS ETAPAS ANTERIORES & \\
\hline SALDO DISPONÍVEL P/ COMPRA DE MATERIAL NESTA ETAPA & $R \$ 4.676,08$ \\
\hline
\end{tabular}

COMPROMISSOS COM A CAIXA TODAS AS ETAPAS

CONSTRUIR RESIDÊNCIA "TIPOLOGIA PADRÃO 1" COM 52,12m2.

CONTRAPISO, COBERURA CERÂMICA E REBOCO EXTERNO TOTAIS.

HIDRÁULICA, ELÉTRICA, PORTAS E JANELAS DE TODOS OS AMBIENTES.

AZULEJO MÍNIMO NO BOXE SOBRE A PIA DA COZINHA $(5,36 \mathrm{~m} 2)$.

PINTURA ACRÍLICA EXTERNADE TODAACASA.

FOSSA SEPTICA CONFORME PADRÃO INCRA.

\section{SUGESTÃO DE OBRA PARA ESTA ETAPA}

FINALIZAR COBERTURA EMBOÇANDO CUMEEIRA. FINALIZAR INSTALAÇÕES ELÉTRICA, HIDRÁULICAE A FOSSA. FINALZIAR REBOCO EXTERNO, COLOCAR AZULEJO MÍNIMO NA COZINHA. FAZER PINTURA EXTERNA TOTAL.

1.NÃO ULTRAPASSAR VALOR DO SALDO DISPONÍVEL PARA COMPRA DE MATERIAL NESTA ETAPA; 2. ADEQUAR ORÇAMENTO À NECESSIDADE DA OBRA. 3. NÃO É PERMITIDO GASTAR O VALOR DE PEDREIRO EM MATERIAL

SÃO PAULO 5 de DEZEMBRO de 2008

Local e data

Responsável Técnico

Figura 4 - Plano de Obra.

Fonte: Acervo Moradia Rural, out. 2008. 
As primeiras liberações de compra ocorreram somente no final de 2007. Para as liberações, era necessário ir ao assentamento esclarecer como funcionava a lista de material ou o plano de obra, organizar as compras e ainda os grupos mutirantes. Ou seja, a demanda de trabalho era grande, e a EMR contava com poucos profissionais. Assim, em acordo com o gabinete, definiu-se a contratação de uma assistência técnica (ATEC) que seria responsável pela execução, enquanto a EMR seria responsável pela supervisão técnica das obras.

A ATEC era composta por um arquiteto ou engenheiro civil, preferencialmente da região onde se encontrava o assentamento. Suas responsabilidades eram organizar os grupos mutirantes, organizar as compras, averiguar a qualidade dos materiais entregues na obra, avaliar a necessidade de contratação de mão de obra especializada (pedreiros e/ou mestres de obra), responder e solucionar dúvidas a respeito da execução da obra, e, por fim, produzir relatórios (inclusive fotográficos) sobre o andamento das obras.

A contratação dava-se via RPA (recibo de pagamento a autônomo), com no máximo duzentas unidades contratadas por profissional. $\mathrm{O}$ valor de cada unidade contratada foi estipulado considerando a distância que o profissional iria percorrer para vistoriar todas as suas unidades, e a partir do valor que cada empreendimento tinha disponível para gastar ${ }^{96}$. Para o pagamento na Caixa, era necessário emitir uma nota fiscal, e o INCRA/SP, estipulou que a ATES (na época a Fundação de Estudos e Pesquisas Agrícolas e Florestais) emitiria a nota, recebendo apenas o custo de sua emissão. A composição do valor a ser pago para ATEC, em nenhum dos casos, atingiu o valor máximo disponível, assim, o recurso restante poderia ser revertido para a compra de material de construção na última etapa de obra.

O pagamento à ATEC só era autorizado pela EMR depois de avaliado o material da vistoria feita pelo profissional. Assim, a ATEC só recebia por obra executada. Se o assentado comprasse material, mas sua execução de obra não

96 O valor disponível de cada empreendimento para pagamento de assistência técnica é dado pela soma dos valores individuais contratados. Lembramos que cada contratação individual dispunha de até $4,5 \%$ do valor da obra para pagamento da ATEC. 
atingisse o percentual maior ou igual ao da liberação dos recursos, a ATEC não receberia por aquela obra. Nos casos de beneficiários irregulares com o INCRA, a ATEC também não receberia.

Foram contratadas 17 ATEC no estado, as quais atendiam 2.551 assentados distribuídos em 42 PA. A maioria dessas contratações se deu com profissional contratado na região, menor valor de subsídio contratado e sem recursos do INCRA/SP a aplicar.

Três outras assistências técnicas no estado prestaram serviços aos contratados do Acordo Caixa X INCRA/SP: Cooperhaf, FAAFOP (Federação das Associações dos Assentados e Agricultores Familiares do Oeste Paulista) e HABIS (Grupo de Pesquisa em Habitação e Sustentabilidade ${ }^{97}$ ). Nesses casos, os assentamentos solicitaram, via ata de assembleia, ao INCRA/SP essas ATEC específicas, que não seguiam o formato proposto, nem eram supervisionadas pela EMR. Nesses casos, os pagamentos foram estipulados de acordo com os valores totais contratados individualmente. Ou seja, utilizavam todo recurso disponível para o pagamento da Assistência Técnica.

Os assentamentos que eram assistidos pela Cooperhaf passaram para a tutela da EMR ao longo do processo de execução das obras. Já o grupo HABIS mantém suas atividades no assentamento, no intuito de finalizar as obras.

Sobre a FAAFOP, a notícia que se teve, em 2011, foi de que haviam suspendido todas as suas atividades por conta de uma denúncia de desvio de recursos destinados a produção de biodiesel em assentamentos, num convênio firmado com o MDA. A denúncia está sendo investigada pela Polícia Federal e as obras estão inacabadas.

Os problemas de execução de obra em si foram resolvidos, em geral, ao longo do processo. O papel da ATEC em campo, assessorando diretamente os beneficiários, foi fundamental para evitar, especialmente, a má execução ou mesmo execução

${ }^{97}$ HABIS: Grupo de Pesquisa em Habitação e Sustentabilidade - IAU USP (Instituto de Arquitetura e Urbanismo da Universidade de São Paulo)/ DECiv UFSCar (Departamento de Engenharia Civil da Universidade Federal de São Carlos). 
errada de algum serviço. Um caso bastante emblemático foi em relação à execução do reboco externo em detrimento ao interno. Isso acontecia quando o beneficiário não tinha recursos suficientes para executar os dois serviços, mas sua vontade era executar o reboco interno. Porém a recomendação técnica era que executasse o reboco externo, pois protegia a casa de intempéries, preservando-a.

Foi o caso das questões de habitabilidade mínima, definas pela Caixa, que priorizava o. Segundo as normativas técnicas, da locação das fossas, ou mesmo da necessidade em executar reparos na elétrica e hidráulica.

Mas já nas primeiras vistorias foi possível verificar que muitos beneficiários modificavam seus projetos originais, executando outros serviços ou ampliações que não estavam previstos na contratação. Essas alterações geravam um problema na medição dos serviços executados, pois aquele serviço executado não constava em sua planilha. Era como se o beneficiário tivesse comprado material, mas não aplicado em obra.

Para esses casos, foi criado o instrumento de alteração de objeto. A EMR alterava a proposta original do beneficiário para que aquele serviço executado constasse em sua contratação e fosse possível medi-lo. As alterações de objeto eram feitas dentro do valor contratado originalmente, sem ultrapassá-lo. Para o ajuste aos novos serviços, alterava-se, em geral, o valor de mão de obra mutirante contratada. Em alguns casos, o mesmo beneficiário teve mais de uma alteração de objeto.

O primeiro problema de fato encontrado nas obras era relativo à baixa execução de obra. Havia muitos casos em que os beneficiários compravam materiais, mas não executavam a obra dentro do prazo estipulado, mantendo os materiais estocados. Para esses casos, a EMR junto com as chefias dos escritórios notificava o beneficiário atrasado. Esta notificação dava um prazo de 30 dias para o beneficiário concluir a aplicação do material adquirido. Caso não ocorresse a conclusão da etapa de obra, sem justificativa, o beneficiário estava sujeito a perder o lote. Nenhuma das notificações aplicadas chegou a ponto de executar essa medida administrativa de exclusão do beneficiário do Programa de Reforma Agrária. 
Outro caso de notificação de beneficiário dava-se quando havia desvio de recurso, ou aplicação do material adquirido em outra construção que não aquela contratada. Esses beneficiários notificados deveriam regularizar sua situação comprando novamente os materiais, agora com recursos próprios.

Os problemas mais graves para o andamento das obras foram relativos aos beneficiários irregulares perante o INCRA. São os casos de abandono ou venda de lote. Nessa situação, se o beneficiário não teve gastos de recursos do Programa de Moradia INCRA/SP, era solicitada à Caixa sua exclusão, e os recursos do FGTS eram devolvidos ao fundo.

O problema é maior nos casos em que houve gastos dos recursos. Isso porque o processo de moralização do INCRA, que permite o ingresso de uma nova família em substituição ao beneficiário irregular naquele lote, em muitos casos é muito lento, podendo levar anos. A solução para esse impasse foi dada, em parte, com um mutirão de moralização do INCRA/SP. Para diversos casos já existe uma nova família homologada morando nos lotes antes vagos, e prontas a assumir o financiamento com a Caixa. É necessário apenas a formalização dessa substituição ${ }^{98}$. Porém, ainda há casos em que medidas judiciais foram tomadas, e o processo de moralização ainda não foi finalizado. A sugestão da Caixa é que os recursos gastos sejam devolvidos ao FGTS. Mas de onde viria o dinheiro? Esse impasse permanece.

Em termos de execução de obra, há um problema específico no assentamento Sepé Tiarajú, no município de Serrana (região de Ribeirão Preto). Os assentados optaram pela assistência técnica prestada pelo grupo HABIS, pois desejavam executar as obras com técnicas alternativas de construção, como taipa de pilão, adobe ou tijolo de solo-cimento.

98 Nos casos de substituição, exclusão ou desistência do Programa, o beneficiário original permanece no cadastro de mutuários da Caixa - CADMUT ativo, e novo beneficiário também. 
Por causa da experiência no Assentamento Pirituba (Itapeva - SP), em 2003, via Projeto Inovarural ${ }^{99}$, o HABIS foi procurado pelo movimento social do assentamento Sepé, que contratou 77 casas novas no Programa, sendo 10 delas contratadas com técnicas alternativas.

Essa obra se tornou um problema por que durante a execução das técnicas alternativas, algumas casas caíram (Imagem 13) e não havia como repor esse recurso dentro dos valores contratados com a Caixa nem pelo HABIS, nem pelos beneficiários. Assim, a obra foi paralisada e o dinheiro acabou, até mesmo por conta do longo tempo de execução de obra, o que encareceu o orçamento também das construções tradicionais, e as obras não terminaram.
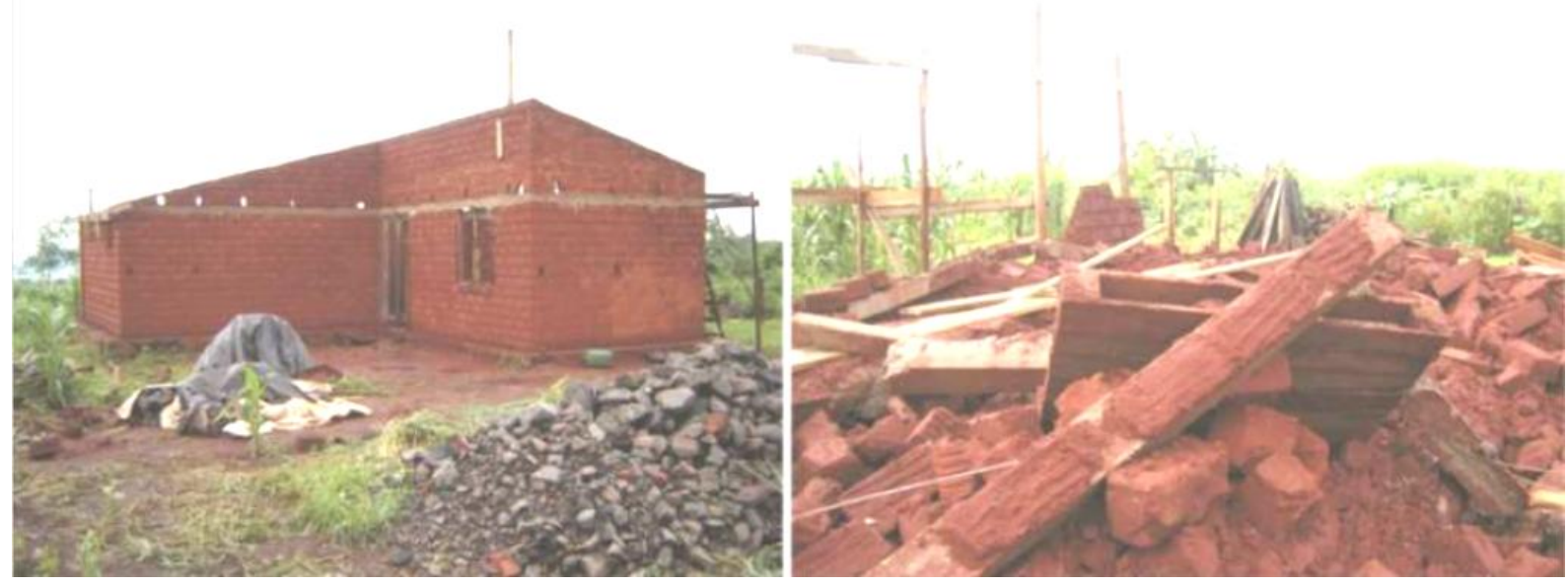

Figura 5 - Casa de adobe no PA Sepé Tiarajú antes e após o colapso.

Segundo o grupo Habis, após longo período de chuvas e ventos no Assentamento, em outubro de 2007, duas paredes da habitação ruíram. Após mais dois meses de exposição às intempéries, o restante da habitação colapsou.

Fonte: HABIS, 2008. In: MAIA, R. T., 2011.

99 O Projeto Inovarural - "Habitação Rural com inovação no processo de produção: Participação, Geração de Renda e Aplicação de Sistemas Construtivos com Recursos Locais e Renováveis", foi desenvolvido entre 2003 e 2007, com a coordenação do Grupo HABIS, EESC/USP - Escola de Engenharia de São Carlos e a UFSCar - Universidade Federal de São Carlos. O financiamento da pesquisa ficou a cargo da FAPESP, Programa Habitare - FINEP/Fundo Verde-Amarelo (2004-06) e Caixa Econômica Federal. O financiamento de materiais de construção ocorreu via PSH. O projeto envolveu a construção de 49 moradias (42 casas novas e 7 reformas) no Assentamento Pirituba II (Itapeva - SP), além da formação de uma cooperativa de marceneiras. (GRUPO HABIS, 2007). 
Em 2008, o gabinete estava descontente com a Equipe de Moradia Rural por achar que as obras estavam demorando muito para terminar e a pressão dos movimentos, principalmente da região de Andradina, só aumentava. Em janeiro de 2009, o Superintendente Substituto impõe à EMR que termine as obras da região de Andradina, deixando o "restante das obras do estado para mais tarde". Essa decisão implicava em transferir a equipe para a UA Andradina.

A EMR então decidiu que não era certo priorizar uma região em detrimento das outras, e que não havia possibilidade de mudança para a cidade de Andradina, assim, sem alternativa, os membros deixaram o INCRA/SP. Duas pessoas foram designadas para tomar conhecimento dos procedimentos da EMR - uma coordenadora (indicação política do Gabinete) e um engenheiro civil. Por algumas semanas, o trabalho da EMR foi o de passar os procedimentos para essa nova equipe, até se desligar completamente do INCRA/SP. Com a notícia da dissolução da EMR, algumas ATEC demitiram-se, restando apenas o pessoal contratado na região de Andradina e Promissão.

Após a dissolução da Equipe de Moradia Rural, a nova coordenadora da habitação, que não era da área técnica, contratou quatro técnicos em edificações para compor a nova equipe, junto com um engenheiro civil. Conforme ordem do gabinete, a equipe foi transferida para a UA Andradina e as obras dessa região foram priorizadas. Trata-se das obras de 18 PA que somam 1.814 unidades, o que representa pouco mais de 59\% do total das contratações no estado.

A nova equipe de habitação chegou à última medição em 9 PA ao final de 2012. Essas obras, teoricamente, estão concluídas, faltando apenas o acesso aos juros que restam nas contas. Os outros 9 PA da região estão na quarta e última etapa de obra, faltando fazer a última medição, além do acesso aos juros.

Somente o PA Rosely Nunes, no município de Itapura - SP, acessou os juros, finalizando por completo os recursos disponíveis na Caixa. Isto foi possível por causa da forte liderança do assentamento, que foi até a Caixa e resolveu diretamente com a engenharia como seria feita essa liberação. 
O escritório regional de Promissão manteve em seu quadro de funcionários o administrativo que era da antiga Equipe de Moradia Rural, e ele continuou executando as obras com ajuda das assistências técnicas. São as obras de 10 PA que somam 728 unidades contratadas (pouco mais de $23 \%$ do total contratado no estado). Dessas obras, nenhuma chegou à última etapa ou à última medição até o final de 2012.

O "restante" das obras do estado só tiveram assessoria da equipe de habitação quando pressionaram o INCRA/SP, através de ocupações nas Caixas ou nos escritórios regionais. São 29 PA, com 1.433 unidades contratadas, o que representa quase $47 \%$ do total contratado no estado. Dessas obras, apenas o PA Nova Esperança I, em São José dos Campos, finalizou as obras, porém, ainda falta fazer a última medição e acessar os juros restantes nas contas para o encerramento do processo.

Vale ressaltar aqui a dificuldade que essa nova equipe de habitação enfrentou com os trâmites com a Caixa e mesmo com os beneficiários do Programa. A coordenadora da equipe não disponibilizou aos técnicos os arquivos da Equipe de Moradia Rural, talvez por desconhecimento técnico da própria coordenadora ou mesmo por orientação política do INCRA/SP. O fato é que a nova equipe enfrentou grandes dificuldades nas relações com a Caixa e com os beneficiários.

Desde o início do processo de contratação até o presente momento (2013), são 7 anos de execução de Programa de Moradia Rural INCRA/SP e, como se vê, nenhuma contratação foi de fato finalizada. Algumas obras já estão com todos os compromissos com a Caixa executados, porém ainda há recursos a gastar, principalmente dos juros que renderem nas contas, e o processo burocrático de encerramento da obra ainda não foi formalizado.

As obras do PE Dom Tomás Balduíno, que originaram todo o Programa de Moradia Rural INCRA/SP, foram iniciadas em setembro de 2006, com 61 contratações, e foram finalizadas em julho de 2008. Esse empreendimento teve como EO o próprio movimento social do assentamento, e como assessoria técnica o Grupo Usina. 
A Usina foi convidada pelo MST para finalizar os projetos, aprová-los para financiamento e executar a obra com os assentados. Depois das atividades de discussão de projeto, foram aprovadas 5 tipologias, casas térreas em bloco cerâmico aparente, com cerca de $70 \mathrm{~m}^{2}$. As soluções técnicas são simples (com exceção da tipologia coberta com abóbada) e a complexidade do processo residiu na gestão de uma obra descentralizada, com 61 pequenos canteiros dispersos. A novidade foi a associação de dois financiamentos públicos que por si só seriam insuficientes para se fazer casas dignas, um do INCRA e outro da Caixa Econômica Federal, para a produção de habitações espaçosas e de grande qualidade. (USINA, [2006], n.p.).

A assessoria técnica do Grupo Usina organizou a obra em sistema efetivo de mutirão, no qual todas as 61 famílias contratadas trabalhavam dois dias na semana. Havia também o trabalho pago: uma "brigada com ajuda de custo" que trabalhava dois dias na semana (composta por assentados) e trabalhadores externos contratados fora do assentamento (mão de obra especializada). Uma equipe de gestão, compras e distribuição composta por arquitetos da Usina, lideranças do movimento social e assentados gerenciava a obra em, pelo menos, quatro dias na semana.

A definição e escolha das tipologias foi feita coletivamente, bem como a organização da obra. Como dificuldades, o Grupo Usina aponta:

[...] a diferenciação financeira entre as tipologias; pré-identificação dos donos de cada casa; dispersão da obra em lotes isolados; formação de agricultores na construção civil; brigadas: empreitadas individuais e crise do mutirão; fragilidade/limitações da organização coletiva; poucas atividades de formação e debate; demora do processo (de 12 para 22 meses); limite do financiamento (insuficiências); poucos recursos para estrutura de suporte a obra (administração); precarizações múltiplas do trabalho (mutirantes e assessoria técnica). (Usina, São Carlos - SP, maio 2011) ${ }^{100 .}$

Mesmo diante de tantas dificuldades esse foi o único empreendimento no estado, dentro das contratações do Programa Moradia Rural INCRA/SP, que foi finalizado. E, mais importante ainda, o próprio movimento social do assentamento foi a Entidade Organizadora de suas obras.

100 Informação verbal: $2^{\circ}$ Colóquio habitat e cidadania: habitação social no campo, 18 a 20 maio 2 011, São Carlos - SP. 
Importante salientar que esse foi o único empreendimento onde o mutirão de obra funcionou. Na maior parte das obras do Moradia Rural, cada família utilizava de recursos próprios para o pagamento de pedreiros, normalmente a partir da venda de animais ou bens.

\subsection{O aprendizado a partir do Programa Moradia Rural INCRA/SP.}

O Programa Moradia Rural INCRA/SP surgiu da adaptação da Resolução 460/2004 do Conselho Curador FGTS ao universo da Reforma Agrária. A execução de um programa adaptado de uma modalidade urbana nos revela, de um lado, a pouca importância com que a habitação rural para as faixas de renda mais baixas no Brasil era tratada até os anos recentes, e de outro, a grande demanda social reprimida - para esse tipo de contratação.

A tamanha burocratização dos processos do INCRA e da Caixa, só reforça a ideia de pouco protagonismo da habitação rural para os mais pobres no Brasil. Mesmo com as últimas medições entregues na Caixa e os juros acessados, ainda que por um PA apenas, não há nenhuma formalização de finalização dos processos pela Caixa, tampouco pelo INCRA/SP. Não podemos esquecer o caso dos “idosos", e também os de substituição ou exclusão de beneficiários - processos que poderiam ser simples e rápidos, mas que até agora não obtiveram desfecho.

Mas uma adaptação importante foi referente à comprovação da renda dos beneficiários pela EO, garantindo o maior valor de subsídio para contratação. Também a adaptação da garantia caução dada pela EO para "fundo perdido", proporcionando a contratação via subsídio total, sem retorno ao agente financiador, revela o alcance às faixas de renda mais baixas que o Programa obteve.

Outro ponto positivo a ser destacado da experiência do Programa Moradia Rural pode ser constatado na obrigatoriedade da EO em manter uma equipe técnica de monitoramento durante todo o processo de obra. E ainda a boa solução dada por essa Equipe em contratar assistências técnicas locais para a execução da obra. 
Por outro lado, outras adaptações foram bastante comprometedoras ao andamento do Programa. É o caso da exigência da Caixa de execução e comprovação de trabalho técnico social, como responsabilidade da EO. O Superintendente do INCRA/SP, na época, entendia que a Reforma Agrária por si só já se configurava como trabalho social, e assim, não era necessário manter na equipe técnica de monitoramento do Programa um profissional para execução desse trabalho social.

Mas, nos parece claro que a falta de execução de um trabalho técnico social voltado especificamente a questões do mutirão de obra, das contratações do Programa e exigências técnicas da Caixa, como a habitabilidade mínima, por exemplo, foi crucial pra a gestão não participativa observada ao longo das obras do Programa de Moradia Rural.

A questão do sistema de obra - mutirão - merece maior atenção. Talvez aqui esteja o maior equívoco deste Programa: o de confundir o trabalho comunitário com o coletivo. No trabalho coletivo, a quantidade de trabalho é o elemento de mediação e regulação. No trabalho comunitário não há regulação, trabalha-se segundo a necessidade ou a possibilidade.

O mutirão de obra é muitas vezes confundido com o mutirão camponês, que trata de relação de ajuda mútua, solidariedade, relativo à moral camponesa que não está mediada pela lógica de acumulação ou exploração. Trata-se de trabalho comunitário. Já o mutirão de obra está totalmente inserido na exploração, na lógica da acumulação, sendo o canteiro de obra um excelente exemplo de divisão do trabalho. Aqui se trata de trabalho coletivo.

Como nos lembra OLIVEIRA (2006), a autoconstrução ou o mutirão rebaixam os custos de reprodução da força de trabalho da classe trabalhadora, ou seja, rebaixase o salário mínimo, pois exclui da "cesta de bens necessária para a reprodução de uma família" o custo da habitação. E ainda o mutirão supõe que as pessoas estejam desempregadas, e isso gera outra questão colocada por esse autor: "você inclui pela exclusão". 
O mutirão é uma espécie de dialética negativa em operação. A dialética negativa age assim: ao invés de elevar o nível da contradição, ela o rebaixa. Elevar o nível da contradição significa atacar o problema da habitação pelos meios do capital. Rebaixar o nível da contradição significa atacar o problema da habitação por meio dos pobres trabalhadores. (OLIVEIRA, 2006, p. 72).

Por fim, devemos lembrar que a maior parte das conquistas dos movimentos sociais de luta pela terra e pela Reforma Agrária são alcançadas através de pressões, reivindicações, e ocupações. Aqui, na experiência relatada do Programa de Moradia Rural não foi diferente. Diversas ocupações nas agências da Caixa, nos escritórios regionais, na UA Andradina e na sede do INCRA/SP foram realizadas desde o início do Programa, com principal reivindicação a conclusão do programa e a inclusão de todos os assentados.

A força dos movimentos sociais foi fundamental na própria construção do Programa de Moradia. Basta lembrarmos que o Programa surge do empenho em captar recursos de uma liderança social de um assentamento. É interessante salientar também que, na ocasião da resolução de acesso aos juros a força de uma liderança política resolveu um problema que os próprios técnicos da Caixa e do INCRA/SP não conseguiram ainda resolver.

O que, por fim, nos parece claro é que a construção de um Programa de Moradia não deve partir de modelos fechados, de adaptações a programas já existentes, o que dificulta a participação e mesmo a identificação dos beneficiários com o programas. Talvez por essa razão o Programa de Moradia Rural tenha encontrado, e continua encontrando, tantas dificuldades para sua conclusão.

Se o objetivo simples de um programa de habitação é a construção de moradias, a análise do programa aqui relatado revela que ele alcançou tal objetivo, independente do tempo que levou, ou ainda da qualidade que se alcançou nessas obras. Porém, se considerarmos a moradia enquanto alavancadora do desenvolvimento dos territórios rurais, que favoreça a permanência do homem no mundo rural, garanta sua produtividade, qualidade de vida e sua reprodução social, a resposta ainda não é clara. 
Devemos lembrar de uma questão fundamental que permeia os territórios rurais brasileiros na atualidade: há muito interesse em fragmentar e enfraquecer a categoria social agricultores familiares, para que esses sujeitos sociais, suas lutas e reivindicações se mantenham marginalizadas. E assim nos perguntamos se as inúmeras reestruturações da equipe de Moradia Rural do INCRA/SP não permeiam este pensamento. 


\section{CONSIDERAÇÕES FINAIS}

A partir da década de 80, as diferenças entre rural e urbano no Brasil passaram a ser cada vez menores ou menos importantes. Um "novo" rural foi percebido, a partir da continuidade da atividade econômica e espacial do urbano no mundo rural. Assim, “o desenvolvimento rural e urbano começam a ser visto como complementares e alvos de políticas públicas interdependentes"' (ZUQUIM, 2008).

Mas ainda existem grandes diferenças nesses espaços no que se refere à cidadania. Não se trata de acesso a serviços e infraestrutura apenas, mas de direitos humanos fundamentais, e ainda de direito à cidade, afinal, como preconiza o Estatuto da Cidade, o rural também faz parte da cidade.

Os sujeitos sociais rurais que mais sofrem sem acesso à cidadania no mundo rural brasileiro, podem ser caracterizados a partir da reunião de subcategorias da Agricultura Familiar: pequenos produtores, minifundiários, assentados de projetos de Reforma Agrária e agricultores familiares com acesso precário à terra. São os pequenos agricultores familiares pobres.

Estratificar a categoria Agricultura Familiar em subgrupos a partir de diferentes relações sociais de produção, práticas sociais distintas, além da diferenciação inevitável que o capital produz nos grupos sociais, deveria ser prática natural de governos e pensadores, para que políticas públicas para essas subcategorias fossem melhor pensadas e implementadas.

Mas, como visto, o atual governo fez a "opção estratégica" pelo modelo do agronegócio e consolidou a dominação dessa categoria social em detrimento da Agricultura Familiar. Assim, a estratificação dos sujeitos sociais rurais no Brasil se limita a agronegócio versus Agricultura Familiar, envolvendo uma disputa política, econômica e territorial que mantém os diversos sujeitos sociais Agricultores Familiares marginalizados, e ainda mantém os mais pobres sem acesso à terra, água, eletrificação, estradas, habitação, educação, saúde, assistência social, etc. 
Nesse sentido, as diferenças entre rural e urbano interessam para a formulação de políticas públicas com vistas à diminuição desse quadro de pobreza e de falta de cidadania nos territórios rurais. Deparamos-nos, por tanto, com a necessidade de ampliar a intersetorialidade e interinstitucionalidade das políticas para o desenvolvimento rural, visando superar o viés histórico que concentra as ações públicas no setor agropecuário. Dessa forma, uma abordagem territorial e de ações integradas, particularmente rural-urbana, para a promoção do desenvolvimento rural deve ser reforçada, inclusive para o controle do violento processo de urbanização, e seu alto custo social, ou seja, "novos avatares dos velhos problemas agrários" (RANGEL, 1979, apud SILVA, 2000).

Assim, políticas de provisão de moradias dignas à população rural mais pobre interessa não só como direito fundamental humano, mas também como alavanca para a superação do atual quadro de pobreza, e, ainda, como promotora do desenvolvimento rural, e consequentemente de desenvolvimento do País. Lembra que o desenvolvimento aqui, não se restringe a crescimento econômico.

Mesmo com a diminuição de cerca de 25\% do déficit habitacional rural nos últimos 5 anos, aproximadamente 742 mil famílias vivem em domicílios em condição de déficit em 2012. O problema se agrava ainda mais quando consideramos a precariedade das habitações rurais, que representam aproximadamente $70 \%$ do déficit rural total (NETO; FURTADO; KRAUSE, 2013).

Perante tal quadro, a adoção de políticas que procurem melhorar as condições habitacionais e, consequentemente, a qualidade de vida no mundo rural torna-se imprescindível. Mas devemos recordar que apenas em 2003 é instituído um Programa Nacional de Habitação Rural (PNHR).

Esse primeiro formato do PNHR englobou modalidades adaptadas à realidade rural de programas já existentes (PSH Rural e CC-FGTS) que movimentos sociais e cooperativas rurais vinham operando. Mas, em função da pressão exercida pelos movimentos de moradia, é criada uma modalidade de HIS voltado para as associações e cooperativas habitacionais autogestionárias, o Programa Crédito Solidário - dado como grande inovação principalmente pelos movimentos sociais. 
Essa primeira configuração do PNHR, formalizou pela primeira vez na história o acesso das famílias rurais ao FGTS, instituiu a organização dos beneficiários por uma Entidade Organizadora, que poderia ser privada e sem fins lucrativos, definiu a obrigatoriedade de assistência técnica e a liberdade de apresentar projetos arquitetônicos sem padronizações. Esse formato do PNHR também inovou ao propor contratações em que a EO deve promover $e$ produzir UH. Porém, exigia contrapartida financeira dos beneficiários, o que refletiu em seu pequeno alcance para as faixas de renda mais baixas da população rural.

O grande salto nas contratações rurais para famílias de baixa renda ocorreu a partir da resolução 460/04 do Conselho Curador do FGTS. O novo modelo do Programa CC-FGTS, operacionalizado ainda no âmbito do primeiro formato do PNHR, considerou a diversidade dos custos de produção e aquisição de imóveis de acordo com o porte e localização dos municípios - que se traduzia em diferentes valores de subsídios por tipo de município, e definiu que quanto menor fosse a renda da família beneficiária, maior seria seu subsídio contratado.

Em 2009, os programas de habitação rural que vinham sendo executados no Brasil são substituídos pelo subprograma do "pacote habitacional" Minha Casa Minha Vida, também chamado de PNHR (em sua nova formatação) ou Programa Minha Casa Minha Vida Rural (PMCMV Rural). Assim, as contratações de programas habitacionais para a população mais pobre no mundo rural, a partir de 2009, passaram a ocorrer somente através desse novo formato do PNHR.

Seguimos então para as considerações a respeito dos avanços e retrocessos apresentados pela nova formatação do programa de habitação rural, a partir da comparação com os programas que vinham sendo executados anteriormente.

Da mesma forma como ocorreu no Programa Moradia Rural em São Paulo, o PMCMV Rural utiliza o ateste de renda dado pelo INCRA para garantir o maior valor de subsídio para os grupos de renda mais baixo. Isso representa o acesso ao programa de uma população que não teria como comprovar renda. E ainda inova ao trazer para o programa o sistema, já consolidado, do PRONAF para definição dos grupos de renda para contratação. 
O novo formato do programa abandona as diferenças de subsídio de acordo com o porte e localização do município, até porque, como vimos a partir da experiência do Moradia Rural, não são só os valores de material de construção que podem variar de um pequeno município para uma grande capital, mas a oferta de materiais, o que também encarece seu valor final. O novo programa também inova ao garantir maiores valores para a região norte do País, em função de custos logísticos.

Da mesma forma que a primeira versão do PNHR, a CC-FGTS exige contrapartida financeira dos beneficiários. Porém possibilita que essas contrapartidas sejam dadas pelas EO em bens ou serviços. Já o PMCMV Rural confere até 96\% de subsídio à população de menor renda. Aqui nos parece que as experiências anteriores, nas quais havia a exigência de contrapartidas, bem como a adaptação do Moradia ao sistema da Caixa para operacionalizar os recursos a "fundo perdido", produziu efeitos.

Uma grande novidade exclusiva do novo formato do PNHR é a constituição de uma comissão de representantes formada por beneficiários e EO para o acompanhamento da execução das obras. Além disso, há ainda a obrigatoriedade de execução do trabalho social nas etapas pré e pós-ocupação, ou seja, além de responsabilizar-se pela conclusão das obras, a EO deve responsabilizar-se pela adequada apropriação das obras e serviços pelos beneficiários finais.

Esse pode ser um ponto crucial na qualidade que as obras do PMCMV Rural podem alcançar. Afinal, aponta-se como grande falha na execução do Moradia exatamente a falta do trabalho social, bem como as dificuldades de organização das contratações e acompanhamento das obras pela Equipe de Moradia Rural. Vale lembrar que foi também pela questão da assessoria técnica que se firmou a parceria entre INCRA e UFRGS e entre INCRA e GERAH.

$\mathrm{O}$ atendimento prioritário do PMCMV Rural às famílias com mulheres responsáveis pela unidade familiar, idosos e pessoas com deficiência, posseiros, comunidades tradicionais e às famílias em situação de emergência ou calamidade pública revela-nos um esforço do governo para alcançar todos os sujeitos sociais 
rurais pobres, e ainda a superação de parte da excessiva burocracia dos agentes financeiros, principalmente em relação a questões de regularização fundiária.

Nesse mesmo entendimento, podemos enquadrar o não estabelecimento de idade máxima para a contratação dos beneficiários do grupo de renda mais baixa. Outro ponto que nos revela a superação - também parcial - do excesso de burocracia é a possibilidade dos assentados de Reforma Agrária formarem grupos maiores de 50 UH para a contratação.

Mas ainda há muita burocracia a ser superada, como os casos de alteração de objeto contratado, a formalização de substituição de beneficiários, principalmente assentados de Reforma Agrária e a introdução de técnicas e materiais de construção alternativos - reivindicação antiga de movimentos sociais de produção de moradia rural.

Um erro que ocorreu no Programa Moradia INCRA/SP foi o fato das contratações seguirem a ordem alfabética das Relações de Beneficiários de cada assentamento. Certamente, a instituição de uma EO pode evitar esse mesmo erro, organizando os grupos por proximidade e/ou afinidade. Essa é, inclusive, uma orientação que deve ser dada às EO.

Mais uma novidade do PMCMV Rural é a distribuição das metas e recursos do programa de acordo com a participação de cada região no déficit habitacional rural do país, como preconizava a PNH e o PlanHab, o que nos parece ter clara relação com os preceitos de desenvolvimento territorial.

Por fim, mais uma grande novidade do PMCMV Rural é sua aderência a programas sociais como o Programa Cisternas, o Territórios da Cidadania e ainda o Brasil Sem Miséria, demonstrando a percepção do governo para a necessidade de ampliar a intersetorialidade e interinstitucionalidade das politicas para o desenvolvimento rural, destacadas anteriormente.

Mas não podemos ignorar a crítica aos sistemas de obras que o PMCMV Rural define, em particular, à autoconstrução e ao mutirão, que rebaixam os custos de reprodução da força de trabalho da classe trabalhadora, e ainda supõe que as pessoas 
estejam desempregadas - "você inclui pela exclusão" (OLIVEIRA, 2006). E sobretudo, lembramos que o mutirão de obra não deve ser confundido com o mutirão camponês.

Mesmo assim, o PMCMV Rural reúne as boas experiências dos programas que vinham sendo executados anteriormente. A princípio, pode-se pensar que se trata de uma "colcha de retalhos", mas, ao fim da análise, podemos dizer que a atual formatação representa grandes avanços e reforça as principais reivindicações dos movimentos sociais organizados na luta por moradia digna no mundo rural.

Não podemos esquecer o papel que esses movimentos sociais de luta pela terra e pela Reforma Agrária têm e sempre tiveram na sociedade brasileira. Em se tratando de habitação rural não é diferente, pois grande parte dos avanços do atual programa são frutos de experiências e/ou reivindicações desses movimentos.

Diante da analise feita aqui, resta responder a uma pergunta: trata-se de uma Política Pública de Habitação Rural?

Política pública não é sinônimo de política estatal. A palavra "pública" não tem identificação exclusiva com o Estado, mas sim com o que em latim se expressa como res publica, isto é, coisa de todos. Assim, a política pública é algo que compromete, simultaneamente, o Estado e a sociedade, através de poder de decisão, controle social e mobilização.

Nessa perspectiva, o PMCMV Rural trata de incentivar o associativismo comunitário, o cooperativismo, o controle social, ou seja, a mobilização social. Mas pouco mobiliza o Estado, principalmente quando as EO não são o próprio Estado. Assim, o papel que os governos municipais e estaduais podem (e devem) ter na formulação e implementação de uma política habitacional mais ampla, não se efetiva.

A instância municipal, ou ainda estadual, adquire extrema importância no processo de desenvolvimento territorial, visto que este deve contemplar também o desenvolvimento local e regional. Apesar da experiência do PRONAF Infraestrutura e Serviços Municipais ter revelado a propensão dessas instâncias às ingerências político-partidárias, elas devem então ser aperfeiçoadas, qualificadas, e não 
abandonadas. E é exatamente o que pretende a PNH quando se apoia no eixo Desenvolvimento Institucional, isto é, a estruturação institucional de Estados, DF e Municípios, e ainda a capacitação de agentes públicos, sociais, técnicos e privados, para a implementação da política.

Da mesma forma, em termos de desenvolvimento territorial, ainda falta a articulação do programa habitacional à integração rural-urbana, para que as áreas rurais deixem de ser tratadas como estoque de área a ser urbanizada, preservando e incentivando suas características sócio-territoriais.

Por fim, a alocação de recursos habitacionais em outros marcos legais, como o PMCMV, esvaziou o SNHIS, que exige de estados e municípios a criação de uma estrutura institucional, com fundo, conselho e plano de habitação, para acesso aos recursos federais, concentrando todos os recursos da política habitacional. Dessa forma, mais uma vez, o fortalecimento da instância local é prejudicado. Talvez aqui esteja o grande gargalo do programa rural: não reverter o quadro de entraves da gestão pública.

Por fim, a construção de uma política publica de habitação rural deve envolver diretamente seus beneficiários, não só no controle, mas na construção da política diante de um processo participativo, incorporando aspectos como os construtivos, ambientais, sociais, culturais, políticos e econômicos, reforçando e estimulando as territorialidades rurais. E mais, incorporar a política habitacional ao desenvolvimento territorial, através da integração rural-urbana, e do empoderamento da instância local deve ser corroborado. 


\section{REFERÊNCIAS 101}

ABRAMOVAY, Ricardo. Funções e medidas da ruralidade no desenvolvimento Contemporâneo. Rio de Janeiro: MPOG/IPEA, texto para discussão n. 702, jan. 2000.

. O futuro das regiões rurais. Porto Alegre: UFGRS, 2009.

BERGAMASCO, Sônia Maria Pessoa Pereira; NORDER, Luiz Antônio Cabello. O que são assentamentos rurais. São Paulo: Brasiliense, 1996.

BRASIL. II Plano Nacional de Reforma Agrária. Paz, Produção e Qualidade de Vida no Meio Rural. Brasília: MDA/INCRA, 2003b.

BANCO DO BRASIL. Programa Cisternas. [2013a]. Disponível em:

$<$ http://www.bb.com.br/docs/pub/inst/dwn/TermoRefCisternas.pdf $>$. Acesso em: 11 dez. 2013.

. CAIXA ECONÔMICA FEDERAL. Habitação. [2009a] Disponível em:

<http://www.caixa.gov.br/novo_habitacao/>. Acesso em: 14 ago. 2009.

. CONSELHO CURADOR DO FUNDO DE GARANTIA DO TEMPO DE

SERVIÇO. Resolução n ${ }^{\circ}$ 460, de 14 de dezembro de 2004a. Diário Oficial da União,

Brasília, 20 dez. 2004. Seção I, Página 87.

.Constituição (1934). Constituição da República dos Estados Unidos do Brasil. 1934. Disponível em:

<http://www.planalto.gov.br/ccivil_03/constituicao/constituicao34.htm>. Acesso em: 10 abr. 2012.

Constituição (1946). Constituição dos Estados Unidos do Brasil. 1946.

Disponível em:

$<$ http://www.planalto.gov.br/ccivil_03/constituicao/constituicao46.htm $>$. Acesso em: 10 abr. 2012.

101 De acordo com a Associação Brasileira de Normas Técnicas. NBR 6023. 
BRASIL. Constituição (1988). Constituição da República Federativa do Brasil. 1988a. Disponível em:

<http://www.planalto.gov.br/ccivil_03/constituicao/constitui\%C3\%A7ao.htm>. Acesso em: 10 abr. 2012.

Constituição (1988). Emenda Constitucional n. 26, de 14 de fevereiro de 2000. 1988b. Disponível em:

<http://www.planalto.gov.br/ccivil_03/constituicao/Emendas/Emc/emc26.htm>. Acesso em: Acesso em: 19 jul. 2012.

Decreto-Lei $\mathrm{n}^{\circ} 311$, de 2 de março de 1938. Dispõe sobre a divisão territorial do país. 1938. Disponível em:

<http:// www6.senado.gov.br/legislacao/ListaNormas.action?numero=311\&tipo_n orma $=$ DEL\&data $=19380302 \&$ link=s $>$. Acesso em: 20 maio 2012.

Decreto ${ }^{\circ} 1.946$, de 28 de junho de 1996. Cria o Programa Nacional de Fortalecimento da Agricultura Familiar - PRONAF, e dá outras providências. 1996a. Disponível em:

<http:/ / legis.senado.gov.br/legislacao/ListaPublicacoes.action?id=143757\&tipoDoc umento=DEC\&tipoTexto=PUB.. . Acesso em: 10 abr. 2012.

EMPRESA BRASIL DE COMUNICAÇÃO. Governo lança programa de habitação rural para 6.300 famílias. In: Agência Brasil, 2003a. Disponível em: <http:// memoria.ebc.com.br/agenciabrasil/noticia/2003-12-05/governo-lancaprograma-de-habitacao-rural-para-6300-familias>. Acesso em: 27 jun. 2011.

FUNDO NACIONAL DE DESENVOLVIMENTO DA EDUCAÇÃO - FNDE. Programa Nacional de Alimentação Escolar - PNAE. [2012a]. Disponível em: <http://www.fnde.gov.br/programas/alimentacao-escolar/alimentacao-escolarapresentacao >. Acesso em: 19 jul. 2012.

Lei n ${ }^{0} 4.380$, de 21 de agosto de 1964. (Lei da Habitação). Institui a correção monetária nos contratos imobiliários de interesse social, o sistema financeiro para a aquisição da casa própria, cria o Banco Nacional da Habitação - BNH, e sociedades de crédito imobiliário, as letras imobiliárias, o Serviço Federal de Habitação e Urbanismo e dá outras providências. 1964a. Disponível em:

<http:// www.planalto.gov.br/ccivil_03/leis/L4380.htm.>. Acesso em: 20 abr. 2011.

Lei no 4.504, de 30 de novembro de 1964. Dispõe sobre o Estatuto da Terra e dá outras providências. 1964b. Disponível em:

<http://www.planalto.gov.br/ccivil_03/leis/L4504.htm>. Acesso em: 19 jun. 2012. 
BRASIL. Lei n ${ }^{\circ} 6.766$, de 19 de dezembro de 1979. Dispõe sobre o parcelamento do solo urbano, e dá outras providências. Disponível em:

<http://www.planalto.gov.br/ccivil_03/leis/16766.htm>. Acesso em: 24 abr. 2012.

Lei $\mathrm{n}^{\text {o }}$ 8.171, de 17 de janeiro de 1991. Dispõe sobre a política agrícola. 1991a. Disponível em: <http://www.planalto.gov.br/ccivil_03/leis/18171.htm..>. Acesso em: 20 jul. 2012.

Lei no 8.213, de 24 de julho de 1991. Dispõe sobre os Planos de Benefícios da Previdência Social, e dá outras providências. 1991b. Disponível em:

<http://www.planalto.gov.br/ccivil_03/leis/18213cons.htm>. Acesso em: 20 jul. 2012.

. Lei $\mathrm{n}^{\mathrm{o}} 10.257$, de 10 de julho de 2001. Regulamenta os arts. 182 e 183 da Constituição Federal, estabelece diretrizes gerais da política urbana e dá outras providências.(Estatuto da Cidade). 2001. Disponível em:

<http://www.planalto.gov.br/ccivil_03/leis/LEIS_2001/L10257.htm>. Acesso em: 24 abr. 2012.

Lei $\mathrm{n}^{\circ} 11.124$, de 16 de junho de 2005. Dispõe sobre o Sistema Nacional de Habitação de Interesse Social - SNHIS, cria o Fundo Nacional de Habitação de Interesse Social - FNHIS e institui o Conselho Gestor do FNHIS. 2005. Disponível em: <http://www.planalto.gov.br/ccivil_03/_ato2004-2006/2005/lei/111124.htm.>. Acesso em: 24 abr. 2012.

. Lei $\mathrm{n}^{\mathrm{0}} 11.326$, de 24 de julho de 2006. Estabelece as diretrizes para a formulação da Política Nacional da Agricultura Familiar e Empreendimentos Familiares Rurais. 2006. Disponível em:

<http://www.planalto.gov.br/ccivil_03/_ato2004-2006/2006/lei/111326.htm>. Acesso em: 19 jul. 2012.

Lei n ${ }^{\mathrm{o}} 11.977$, de 07de julho de 2009. Dispõe sobre o Programa Minha Casa, Minha Vida - PMCMV e a regularização fundiária de assentamentos localizados em áreas urbanas; altera o Decreto-Lei no 3.365, de 21 de junho de 1941, as Leis nos 4.380, de 21 de agosto de 1964, 6.015, de 31 de dezembro de 1973, 8.036, de 11 de maio de 1990, e 10.257, de 10 de julho de 2001, e a Medida Provisória no 2.197-43, de 24 de agosto de 2001; e dá outras providências. 2009b. Disponível em: <http://www.planalto.gov.br/ccivil_03/_ato2007-2010/2009/lei/111977.htm.>. Acesso em: 24 abr. 2012. 
BRASIL. Lei $\mathrm{n}^{\mathrm{o}}$ 12.424, de 16 de junho de 2011. Altera a Lei no 11.977, de 7 de julho de 2009, que dispõe sobre o Programa Minha Casa, Minha Vida - PMCMV e a regularização fundiária de assentamentos localizados em áreas urbanas, as Leis nos 10.188, de 12 de fevereiro de 2001, 6.015, de 31 de dezembro de 1973, 6.766, de 19 de dezembro de 1979, 4.591, de 16 de dezembro de 1964, 8.212, de 24 de julho de 1991, e 10.406, de 10 de janeiro de 2002 - Código Civil; revoga dispositivos da Medida Provisória no 2.197-43, de 24 de agosto de 2001; e dá outras providências. 2011b. Disponível em: <http://www.planalto.gov.br/ccivil_03/_ato20112014/2011/lei/112424.htm.>. Acesso em: 24 abr. 2012.

Plano Nacional de Habitação - PlanHab. Brasília: Ministério das Cidades/ Secretaria Nacional de Habitação, 2010a.

. MINISTÉRIO DA AGRICULTURA, PECUÁRIA E ABASTECIMENTO MAPA. [2012b]. Disponível em: <http://www.agricultura.gov.br/ministerio >. Acesso em: 19 jul. 2012.

. MINISTÉRIO DAS CIDADES - MCidades. Programa de Subsídio à Habitação de Interesse Social - PSH. [2011a]. Disponível em:

<http://www.cidades.gov.br/index.php?option=com_content\&view=article\&id=51 2:psh\&catid=94\&Itemid=126>. Acesso em: 27 jun. 2011.

MINISTÉRIO DAS CIDADES - MCidades. Portaria MCidades nº 194, de 30 de abril de 2013. [2013b]. Disponível em:

<http:/ / www.cidades.gov.br/index.php?option=com_content\&view=article\&id=85 8:programa-nacional-de-habitacao-rural-pnhr\&catid=94\&Itemid=126>. Acesso em: 11 dez. 2013.

. MINISTÉRIO DAS CIDADES; CONSELHO CURADOR DO FUNDO DE DESENVOLVIMENTO SOCIAL. Resolução n ${ }^{\circ}$ 93, de 28 de abril de 2004. Diário Oficial da União, Brasília, 03 maio 2004b, Seção I, Página 87.

MINISTÉRIO DAS CIDADES; MINISTÉRIO DA FAZENDA. Portaria Interministerial $n^{\circ}$ 326, de 31 de agosto de 2009. Diário Oficial da União, Brasília, 02 set. 2009c, seção 1, págs. 79- 80 .

Disponível em:

<http://www.mda.gov.br/portal/institucional/Estrutura_do_MDA>. Acesso em: 19 jul. 2012. 
BRASIL. MINISTÉRIO DO DESENVOLVMENTO AGRÁRIO - MDA; INSTITUTO DE COLONIZAÇÃO E REFORMA AGRÁRIA - INCRA. Pesquisa Sobre a Qualidade de Vida, Produção e Renda dos Assentamentos da Reforma Agrária. (PQRA). 2010b, n.p. Disponível em: $<$ http://www.incra.gov.br/index.php/reforma-agraria2/questao-agraria/numeros-da-reforma-agraria/file/1152-pesquisa-qualidade-devida-nos-assentamentos-2010>. Acesso em: Acesso em: 10 abr. 2013.

MINISTÉRIO DO TRABALHO E EMPREGO - MTE. Programa de Geração de Emprego e Renda do FAT - PROGER. [2012d]. Disponível em: <http://proger.mte.gov.br/portalproger/pages/programaselinhasdecredito/proger rural.xhtml>. Acesso em: 19 jul. 2012.

PRESIDÊNCIA DA REPÚBLICA. Destaques março 2013. Ano VI, n.1, nov. 2012/fev. 2013. Brasília: SECOM, 2013c. Disponível em:

$<$ http://www.planejamento.gov.br/secretarias/upload/Arquivos/publicacao/cade rno_destaques/130430_caderno_destaques_mar_2013.pdf.>. Acesso em: 11 dez. 2013.

. SECRETARIA-GERAL DA PRESIDÊNCIA DA REPÚBLICA. Programa Terra Forte. [2013d]. Disponível em: <http:// www.secretariageral.gov.br/terraforte>. Acesso em: 12 mar. 2013.

SENADO. Programa Nacional de Fortalecimento da Agricultura Familiar PRONAF. [1996b]. Disponível em:

<http://legis.senado.gov.br/legislacao/ListaPublicacoes.action?id=143757\&tipoDoc umento=DEC\&tipoTexto=PUB $>$. Acesso em: 10 abr. 2012.

BUAINAIN, Antônio Márcio; GUANZIROLI, Carlos Enrique; SABBATO, Alberto Di. Dez anos de evolução da agricultura familiar no Brasil - 1996-2006. Produto 3. In: Projeto caracterização da agricultura familiar em 2006 e análise de sua evolução entre 1996-2006 com base nos Censos Agropecuários do IBGE. Niterói: FEC - II CA, 2010. p. 3- 5 e p. 52- 81.

BONDUKI, Nabil Georges. Do Projeto Moradia ao Programa Minha Casa, Minha Vida. In: Teoria e Debate, n. 82, p. 8- 14, maio/jun. 2009.

Política habitacional e inclusão social no Brasil: revisão histórica e novas perspectivas no governo Lula. Revista Eletrônica de Arquitetura e Urbanismo arq.urb, São Paulo, n. 01, p. 70- 104, 2008. Disponível em: $<$ http://www.usjt.br/arq.urb/numero_01/artigo_05_180908.pdf.. . Acesso em: 20 abr. 2011. 
CENTRO DE TRABALHOS PARA O AMBIENTE HABITADO - USINA. [2006].

Disponível em: <http://www.usinactah.org.br/index.php?/s/--comuna-da-terra-dtomas-balduino/>. Acesso em: 23 maio 2011.

DEL GROSSI, Mauro Eduardo; SILVA, José Francisco Graziano da. O novo rural: uma abordagem ilustrada. Londrina: Instituto Agronômico do Paraná, 2002. 2v.

; MARQUES, Vicente P. M. de Azevedo. Agricultura familiar no censo agropecuário 2006: o marco legal e as opções para sua identificação. Estudos Sociedade e Agricultura, Rio de Janeiro, vol. 18, no 1, 2010. p. 127-157.

DEPARTAMENTO INTERSINDICAL DE ESTATÍSTICA E ESTUDOS SOCIOECONÔMICOS (DIEESE); NÚCLEO DE ESTUDOS AGRÁRIOS DESENVOLVIMENTO RURAL (NEAD); MINISTÉRIO DO DESENVOLVIMENTO AGRÁRIO (MDA). Estatísticas do Meio Rural 2010-2011. Brasília: MDA, 2011.

GEHLEN, Ivaldo. Políticas públicas e desenvolvimento social rural. Revista São Paulo em Perspectiva, São Paulo, v. 18, n 2, p. 95- 103, 2004.

GOMES DA SILVA, José. A Reforma Agrária no Brasil: Frustração camponesa ou instrumento de desenvolvimento? Rio de Janeiro: Zahar, 1971.

GRUPO HABIS. Projeto Inovarural. [2007]. Disponível em:

<http://www6.ufrgs.br/nuc/habrural/apresentacoespublicas/projetoinovarural/fo lder_inovarural_1_1_.pdf $>$. Acesso em: 13 jun. 2012.

ÍNDICE DE DESENVOLVIMENTO HUMANO - IDH. Disponível em: <http://pt.wikipedia.org/wiki/\%C3\%8Dndice_de_Desenvolvimento_Humano>. Acesso em: 20 maio 2012.

INSTITUTO BRASILEIRO DE GEOGRAFIA E ESTATÍSTICA - IBGE. Censo Agropecuário 2006: Agricultura Familiar - Primeiros Resultados. Brasil, Grandes Regiões e Unidades da Federação. Rio de Janeiro, 2009a.

Censo Agropecuário 2006: Brasil, Grandes Regiões e Unidades da Federação. Rio de Janeiro, 2009b.

Censo Demográfico 2010. Sinopse. [2011a]. Disponível em:

<http://www.censo2010.ibge.gov.br/sinopse/>. Acesso em: 22 jul. 2013. 
INSTITUTO BRASILEIRO DE GEOGRAFIA E ESTATÍSTICA - IBGE. Censo

Demográfico 2010. Resultados Preliminares do Universo. Rio de Janeiro, 2011b.

Disponível em:

<http://www.ipea.gov.br/redeipea/images/pdfs/conceitos_e_definicoes_censo_20 10.pdf> Acesso em: 03 nov. 2013.

INSTITUTO CIDADANIA. Projeto Moradia. São Paulo: Instituto Cidadania, 2000.

INSTITUTO DE PESQUISA ECONÔMICA APLICADA - IPEA. Perspectivas da política social no Brasil. Livro 8. Brasília: IPEA, 2010.

O planejamento da habitação de interesse social no Brasil: desafios e perspectivas, Comunicados n ${ }^{\mathrm{o}}$ 118, Brasília: IPEA, 2011.

INSTITUTO NACIONAL DE COLONIZAÇÃO E REFORMA AGRÁRIA - INCRA. [2010]. Disponível em: <http://www.incra.gov.br>. Acesso em: 03 ago. 2010.

SR O8. Prestação de contas ordinárias anual - Relatório de gestão do exercício de 2010. São Paulo, 2011. Disponível em:

<http:// www.incra.gov.br/portal/index.php?option=com_docman\&task=cat_view \&gid=606\&Itemid=142\&limitstart=7>. Acesso em: 03 nov. 2011.

KAGEYAMA, Ângela Antônia. Desenvolvimento rural: conceitos e aplicações ao caso brasileiro. Porto Alegre: UFRGS, 2008.

MAIA, Rafael Torres. Avaliação das variáveis que influenciaram no uso da terra como material construtivo para habitação social rural no Assentamento Rural Sepé Tiaraju - Serra Azul-SP. 2011. 146f. Dissertação (Mestrado em Arquitetura e Urbanismo) - Escola de Engenharia de São Carlos, Universidade de São Paulo, São Paulo, 2011.

MARICATO, Ermínia. As ideias fora do lugar e o lugar fora das ideias. Planejamento Urbano no Brasil. In: ARANTES, Otília; VAINER, Carlos; MARICATO, Ermínia. $\underline{A}$ cidade do pensamento único: desmanchando consensos. Petrópolis: Vozes, 2000, p. 121- 192.

MEDEIROS, Rosa Maria Vieira. Políticas Públicas e Agricultura Familiar. In: MOREIRA, Emilia; TARGINO, Ivan. (Org.). Desertificação, desenvolvimento 
sustentável e agricultura familiar: recortes no Brasil, em Portugal e na África. João Pessoa: Editora Universitária UFPB/ Ministério do Meio Ambiente, 2010, p. 255-265.

MERCADO COMUM DO SUL - MERCOSUL. Disponível em:

<http://pt.wikipedia.org/wiki/Mercado_Comum_do_Sul >. Acesso em: 03 nov. 2013.

MIRANDA, Lívia Izabel Bezerra de. Planejamento em áreas de transição ruralurbana: velhas novidades em novos territórios. In: ENCONTRO NACIONAL DA ASSOCIAÇÃO NACIONAL DE PÓS-GRADUAÇÃO E PESQUISA EM PLANEJAMENTO URBANO E REGIONAL, XIII, 2009. Florianópolis. Anais... Florianópolis: ANPUR, UFSC, 2009. CD.

MIRANDA, Zoraide Amarante Itapura de. A incorporação de áreas rurais às cidades: um estudo de caso sobre Campinas - SP. 2002. 300 p. Tese (Doutorado em Economia) - Instituto de Economia, Universidade Estadual de Campinas - Unicamp, Campinas, 2002.

MOVIMENTO DOS TRABALHADORES RURAIS SEM TERRA (MST). Carta à Presidenta Dilma Rousseff. maio 2013. Disponível em:

<http://www.mst.org.br/MST-faz-ato-por-Reforma-Agr\%C3\%A1ria-e-protocolacarta-\%C3\%A0-presidenta-Dilma>. Acesso: 20 jun. 2013.

NETO, Vicente Correia Lima; FURTADO, Bernardo Alves; KRAUSE, Cleandro. Estimativas do Déficit Habitacional brasileiro (PNAD 2007-2012), Nota Técnica n. 5, Brasília: IPEA, 2013.

OLIVEIRA, Ariovaldo Umbelino. Modo de Produção Capitalista, Agricultura e Reforma Agrária. São Paulo: FFLCH, 2007.

OLIVEIRA, Francisco de. O vício da virtude. Autoconstrução e acumulação capitalista no Brasil. In: Revista Novos Estudos CEBRAP, São Paulo, n. 74, mar. 2006, p. 67- 85 .

PROJETO DE COOPERAÇÃO TÉCNICA INCRA/ FAO. Novo retrato da agricultura familiar: o Brasil redescoberto. Brasília: INCRA, 2000. 
RANGEL, Ignácio. Fim de linha. São Paulo, 1988. In: SILVA, José Francisco Graziano da (Org.). Questão Agrária, Industrialização e Crise Urbana no Brasil. Porto Alegre: Editora Universidade/ UFRGS, 2000. p. 231- 233.

Questão Agrária e Agricultura. Rio de Janeiro, 1979. In: SILVA, José Francisco Graziano da (Org.). Questão Agrária, Industrialização e Crise Urbana no Brasil. Porto Alegre: Editora Universidade/ UFRGS, 2000. p. 143- 168.

RODRIGUES, Vera Lúcia Graziano da Silva. Urbanização e ruralidade: os condomínios e os conselhos de desenvolvimento municipal. Brasília: MDA, 2009.

ROLNIK, Raquel. A construção de uma política fundiária e de planejamento urbano para o país - avanços e desafios. In: IPEA. Políticas sociais - acompanhamento e análise. Brasília: IPEA, n. 12, fev. 2006. p. 199- 210. Disponível em:

<http://www.ipea.gov.br/portal/images/stories/PDFs/politicas_sociais/bps_12_c ompleto.pdf.> Acesso em: 10 abr. 2012.

; NAKANO, Kazuo. As armadilhas do pacote habitacional. Le Monde Diplomatique Brasil, São Paulo, n. 20, ano 2, mar. 2009. Disponível em: <http:// www.diplomatique.org.br/artigo.php?id=461>. Acesso em: 10 abr. 2012.

ROVER, Oscar José; MUNARINI, Paulo Roberto. A política de habitação rural e o desenvolvimento da agricultura familiar. Revista Katálysis, Florianópolis, v. 13, n. 2, jul./ dez. 2010. p. 260- 269.

SÃO PAULO (ESTADO) FUNDAÇÃO INSTITUTO DE TERRAS DO ESTADO DE SÃO PAULO “José Gomes da Silva” - ITESP. [2012]. Disponível em: <http://www.itesp.sp.gov.br/>. Acesso em: 25 jun. 2012.

SAUER, Sérgio. Agricultura familiar versus agronegócio: a dinâmica sociopolítica no campo brasileiro. Embrapa: Texto para discussão n. 30, 2008.

SCHNEIDER, Sergio; MATTEI, Lauro; CAZELLA, Ademir Antonio. Histórico, caracterização e dinâmica recente do PRONAF - Programa Nacional de Fortalecimento da Agricultura Familiar. In: SCHNEIDER, Sergio; SILVA, Marcelo Kunrath; MARQUES, Paulo Eduardo Moruzzi (Org.). Políticas Públicas e Participação Social no Brasil Rural. Porto Alegre: UFGRS Editora, 2004. p. 21- 50. 
SILVA, José Francisco Graziano da. Questão Agrária, Industrialização e Crise Urbana no Brasil: uma introdução à obra de Ignácio Rangel. In: . (Org.). Questão

Agrária, Industrialização e Crise Urbana no Brasil. Porto Alegre: Editora Universidade/ UFRGS, 2000. p. 7-37.

VILLAÇA, Flávio. Uma contribuição para a história do planejamento urbano no Brasil. In: DEÁK, Csaba; SCHIFFER, Sueli Ramos (Org.). O processo de urbanização no Brasil. São Paulo: EdUSP, 1999. p. 169- 243.

WANDERLEY, Maria de Nazareth Baudel. A emergência de uma nova ruralidade nas sociedades capitalistas avançadas - o "rural" como espaço singular e ator coletivo. In: Estudos Sociedade e Agricultura, Rio de Janeiro, n. 15, out. 2000. p. 87145.

WEBER, Max. Burocracia. [S.1.], 1963. In: GERTH, H. H.; WRIGHT MILLS, C. (Org.). Ensaios de Sociologia. Rio de Janeiro: Livros técnicos e científicos, 1982. Capitulo 8, p. 229- 282.

ZUQUIM, Maria de Lourdes. O lugar do rural nos Planos Diretores Municipais. In: PLURIS - Congresso Luso Brasileiro para Planejamento Urbano, Regional, Integrado e Sustentável, $3^{\circ}$., 2008. São Carlos. Anais... São Carlos: STT/CETEPE/EESC/USP, 2008. 